NBER WORKING PAPER SERIES

\title{
DANCING WITH ACTIVISTS
}

\author{
Lucian A. Bebchuk \\ Alon Brav \\ Wei Jiang \\ Thomas Keusch \\ Working Paper 26171 \\ http://www.nber.org/papers/w26171 \\ NATIONAL BUREAU OF ECONOMIC RESEARCH \\ 1050 Massachusetts Avenue \\ Cambridge, MA 02138 \\ August 2019
}

This discussion paper was prepared for publication in the Journal of Financial Economics. We have benefitted from the comments of Manuel Adelino, Amil Dasgupta, Veljko Fotak, Oliver Hart, Scott Hirst and participants in the 2015 FMA International Consortium on Activist Investors, Corporate Governance and Hedge Funds in London, the 2015 FMA International meeting in Helsinki, and workshops at Harvard, INSEAD, NYU, and Maastricht University. We are especially indebted to an anonymous referee for many valuable suggestions. We also wish to thank Brady Baldwin, Seung Hwan Bang, Vlad Bouchouev, Hannah Clark, Ahmet Degerli, Timothy Goh, Robert Holowka, Wenyin Huang, Kirti Kamboj, Kobi Kastiel, Zheng Li, Cong Liu, Yaron Nili, John Rady, Qingrong Ruan, June Rhee, Ruoxi Tian, Jun Xu, Jiaqi Yang, Zilan Yang, Kailei Ye, and Lu Zheng for their excellent research assistance. Finally, we are also grateful to many practitioners affiliated with the Harvard Law School Program on Corporate Governance, including senior proxy solicitors, investment bankers, and hedge fund officers, for helpful discussions about activist settlements. Financial support was provided by the INSEAD Corporate Governance Centre, Columbia Business School, Duke, and Harvard Law School. The views expressed herein are those of the authors and do not necessarily reflect the views of the National Bureau of Economic Research.

NBER working papers are circulated for discussion and comment purposes. They have not been peer-reviewed or been subject to the review by the NBER Board of Directors that accompanies official NBER publications.

(C) 2019 by Lucian A. Bebchuk, Alon Brav, Wei Jiang, and Thomas Keusch. All rights reserved. Short sections of text, not to exceed two paragraphs, may be quoted without explicit permission provided that full credit, including $(\odot$ notice, is given to the source. 
Dancing With Activists

Lucian A. Bebchuk, Alon Brav, Wei Jiang, and Thomas Keusch

NBER Working Paper No. 26171

August 2019

JEL No. G12,G23,G32,G35,G38,K22

\begin{abstract}
$\underline{\text { ABSTRACT }}$
An important milestone often reached in the life of an activist engagement is entering into a "settlement" agreement between the activist and the target's board. Using a comprehensive handcollected data set, we analyze the drivers, nature, and consequences of such settlement agreements. Settlements are more likely when the activist has a credible threat to win board seats in a proxy fight and when incumbents' reputation concerns are stronger. Consistent with incomplete contracting, face-saving benefits and private information considerations, settlements commonly do not contract directly on operational or leadership changes sought by the activist but rather on board composition changes. Settlements are accompanied by positive stock price reactions, and they are subsequently followed by changes of the type sought by activists, including CEO turnover, higher shareholder payouts, and improved operating performance. We find no evidence to support concerns that settlements enable activists to extract rents at the expense of other investors. Our analysis provides a look into the "black box" of activist engagements and contributes to understanding how activism brings about changes in target companies.
\end{abstract}

Lucian A. Bebchuk Harvard

Law School

1545 Massachusetts Avenue

Cambridge, MA 02138 and

NBER

bebchuk@law.harvard.edu

Alon Brav

Fuqua School of Business

Duke University

One Towerview Drive

Durham, NC 27708

and NBER

brav@duke.edu
Wei Jiang

Graduate School of Business

Columbia University

3022 Broadway, Uris Hall 803

New York, NY 10027

and NBER

wj2006@columbia.edu

Thomas Keusch

INSEAD

Boulevard de Constance

Fontainebleau Cedex 77305

France

thomas.keusch@insead.edu

A data appendix is available at http://www.nber.org/data-appendix/w26171 


\section{Introduction}

In August 2013, Third Point, the hedge fund led by Daniel Loeb, disclosed a significant stake in the auction house Sotheby's, criticized the company for its poor governance and its failure to take advantage of a booming market for luxury goods, and called for the ouster of the company's CEO. Third Point launched a proxy fight for board representation and both sides were preparing for a contested election at the company's upcoming annual meeting. However, the day before the scheduled annual shareholder meeting, the company and the activist fund entered into a settlement agreement in which Sotheby's agreed to appoint three of the Third Point director candidates and Third Point agreed to discontinue the proxy fight. The settlement terms did not require the company to make any of the operational and executive changes that Third Point was seeking. However, ten months later, Sotheby's announced the hiring of a new CEO, the appointment of a new board chairman, and a plan to return capital to its investors.

While such settlements used to be rare, they now occur with significant frequency, and they have been attracting a great deal of media and practitioner attention. Understanding settlement agreements is important for obtaining a complete picture of the corporate governance landscape and the role of activism within it. Using a comprehensive, hand-collected dataset of settlement agreements, this paper provides the first systematic empirical investigation of settlements between activists and target companies. We study the drivers of settlements, their growth over time, the terms of settlements and their impact on board composition, and the stock market reaction accompanying them. We further study the aftermath of settlements in terms of CEO turnover, payouts to shareholders, M\&A activity, and operating performance.

With the growing recognition of the importance of hedge fund activism, a large empirical literature on the subject has emerged [see Brav et al. (2015b) for a recent survey]. This literature has extensively studied the initiation of activist interventions - the time at which activists announce their presence, usually by filing a Schedule 13(d) with the SEC after passing the 5\% ownership threshold, and the stock market reactions accompanying such announcements. ${ }^{1}$ This literature has

\footnotetext{
1 Studies analyzing such initiations, including the stock market reactions accompanying them, and the stock accumulations preceding them, include Clifford (2008); Klein and Zur (2009); Boyson, and Mooradian (2011); Brav, Jiang, Partnoy, and Thomas (2008); Bebchuk, Brav, Jackson, and Jiang (2013); Mietzner and Schweizer (2014); Edmans, Fang, and Zur (2013); Collin-Dufresne and Fos (2015); Becht, Franks, Grant, and Wagner (2017); Norli,
} 
also studied extensively the changes in the value, performance, and behavior of firms in the years following activist interventions; among other things, researchers have studied the changes in Tobin's Q, return on assets (ROA), productivity, innovation, payouts to shareholders, likelihood of an acquisition, divestitures, internal capital markets, and accounting practices that ultimately follow activist interventions. ${ }^{2}$ But there has been limited empirical work on the "black box" in between - the channels through which activists' influence is transmitted and is reflected in targets' economic outcomes. ${ }^{3}$ In particular, the determinants, nature, and role of settlement agreements and the cooperation between activists and companies that they target - have not been subject to a systematic empirical examination. Our study fills this gap. ${ }^{4}$

We begin by quantifying the upward trend in activist settlements. We show that the unconditional likelihood of an activism campaign leading to a settlement increased sevenfold and almost linearly from 3\% for campaign launched in 2000 to $21 \%$ for campaigns launched in 2013. This increase in the prevalence of settlement agreements is much stronger than the increase in contested votes during the same period. While contested votes also occurred in $3 \%$ of all activism campaigns started in 2000, this ratio only increases to $6 \%$ for campaigns started in 2013.

We build on the insights generated by the economics of litigation and settlements to put forward hypotheses concerning the determinants of which cases will produce a settlement, rather than end up without either a contested vote or a settlement. We hypothesize that settlements are more likely in cases in which the activist has good chances to win board seats should a contested

Oostergard, and Schindele (2015); Gantchev and Jotikasthira (2017); Back, Collin-Dufresne, Fos, Li, and Ljungqvist (2018); and Boyson, Ma, and Mooradian (2016).

${ }^{2}$ Studies of the subject include Brav, Jiang, Partnoy, and Thomas (2008); Clifford (2008); Klein and Zur (2009, 2011); Greenwood and Schor (2009); Becht, Franks, Mayer, and Rossi (2009); Boyson and Mooradian (2011); Cheng, Huang, Li, and Stanfield (2012); Sunder, Sunder, and Wongsunwai (2014); Gow, Shin, and Srinivasan (2014, 2016); Cheng, Huang, and Li (2015); Bebchuk, Brav, and Jiang (2015); Brav, Jiang, and Kim (2015a); Boyson and Pichler (2019); Brav, Jiang, Ma, and Tian (2018); Aslan and Kumar (2016); Boyson, Gantchev, and Shivdasani (2017); Boyson, Ma, and Mooradian (2016); Corum and Levit (2018); Gantchev, Gredil, and Jotikasthira (2018); Jiang, Li, and Mei (2018); Krishnan, Partnoy, and Thomas (2016); Johnson and Swem (2017); Swanson and Young (2017); Bourveau and Schoenfeld (2017); Hege and Zhang (2019); Guo, Utham, and Wang (2019); Kim (2018); and Gantchev, Sevilir, and Shivdasani (2019).

${ }^{3}$ Some studies have provided insights on the engagement process [see, e.g., Appel, Gormley, and Keim (2018); Becht, Franks, Mayer, and Rossi (2009); Boyson and Pichler (2019); Corum (2018); Gantchev (2013); He and Li (2018); Levit (2018); and McCahery, Sautner, and Starks (2016)]. However, none of the empirical studies has paid significant attention to investigating settlement agreements and their role.

${ }^{4}$ Recent work by Schoenfeld (2018) studies the determinants (but not the terms or consequences) of contracts between a wide variety of shareholders (not focusing on activists) and publicly-traded companies. In contrast to the settlement agreements in our study, the contracts in his study include a variety of provisions that pertain to financing terms, trading, directorships, payout policy, joint ventures, financial reporting, and selective disclosure. 
vote take place, and we find evidence consistent with this hypothesis. We also hypothesize that settlements are more likely when a contested vote could impose larger reputational costs on incumbents, and we find evidence that is also consistent with that hypothesis. As to timing, we hypothesize that settlements are more likely to take place closer to the time of the target's shareholder meeting, as the arrival of information regarding the outcome of the expected vote narrows any divergence of expectations between the parties, and we provide evidence that is consistent with this hypothesis.

Turning to the terms of settlement, we argue that the terms of settlement agreements can commonly be expected to focus on board turnover rather than to stipulate directly the kind of operational and leadership changes that activists ultimately seek and on which they base their hopes for value appreciation. We put forward three reasons - incomplete contracting that make some direct action commitments infeasible, face-saving benefits, and informational asymmetry that combine to preclude or discourage the incorporation of commitments for direct action. We provide evidence that is consistent with the hypothesis that settlement terms tend to focus on board composition and avoid commitments of direct action. We also find evidence that face-saving benefits, as well as informational asymmetry, at least partly contribute to the documented patterns.

We then turn to investigate systematically the effects of settlements on board composition. We demonstrate that settlements are a key channel through which activists bring about board changes. In particular, we find that settlements are associated with an increase in the number of activist-affiliated, activist-desired and well-connected directors, and decrease the number of old and long-tenured directors.

Next, we document that settlements are accompanied by positive abnormal stock returns. We find that the positive market reaction is especially large when the settlement is of "high impact" in terms of creating a high volume of board turnover or providing for an immediate strategic transaction. We also find that activist engagements that produce settlement agreements are associated with higher abnormal stock returns at the time of the activist's initial 13(d) filing. These patterns are overall consistent with the view that the market views favorably the boardroom 
composition and other changes that activist settlements produce, and are inconsistent with the view that such changes can be expected to be disruptive and detrimental to target shareholders. ${ }^{5}$

Why do activists settle on changes in board composition if their ultimate goal is to bring about operational or leadership changes? We argue that introducing individuals into the boardroom who are aligned with the activist, or at least open to the changes sought by the activist, is an intermediary step that often facilitates such changes. Consistent with this view, we show that, while settlements generally do not stipulate a replacement of the CEO, settlements are followed in the years following the settlement by a considerable increase in CEO turnover and in the performancesensitivity of CEO turnover. Thus, the evidence is consistent with settlements planting the seeds for a subsequent CEO replacement. Similarly, while settlement agreements generally do not require any specific operational changes, settlements might facilitate such changes: consistent with the presence of such an effect, we document that settlements are followed by increased payouts to shareholders and improvements in operating performance.

Finally, we also investigate concerns raised by practitioners and commentators that settlements between activists and targets enable activists to extract rents at the expense of other shareholders who are not "at the bargaining table." 6 We examine two suggested channels for such rent extraction and find little evidence that settlements distribute significant rents to activists at other shareholders' expense. First, we find no evidence to support concerns that settlements enable activists to put on the board directors that are not supported by other shareholders. ${ }^{7}$ In particular, we show that directors who enter the board through settlements do not subsequently receive less voting support at the following annual general meetings than other directors. Second, we also find little evidence that settlements produce a significant incidence of "greenmail" through the target's purchasing of the activist's shares at a premium to the market price. Buybacks of activist shares occur in a very small fraction of settlement agreements and, when they do occur, they are typically executed at the market price.

\footnotetext{
${ }^{5}$ We investigate the effects of activism settlements on a wide array of dimensions, but we do not cover all possibly relevant dimensions. For example, in a recent paper, Coffee et al. (2019) focuses on the effect of such settlements with activists on subsequent "information leakage" prior to the issuance of 8-K filings and on bid-ask spreads.

${ }^{6}$ For recent media accounts, see Reuters, 07/18/2016, "Big Funds Push Back Against Settlement Agreements" and State Street Global Advisors, 10/10/2016, "Protecting Long-Term Shareholder Interests in Activist Engagements."

7 Leading index fund manager State Street Global Advisors expressed such a concern. See State St. Global Advisors, Protecting Long-Term Shareholder Interests In Activist Engagements (2016).
} 
Our analysis is organized as follows. Section 2 discusses the institutional background. Section 3 describes the data collection and sample construction. Section 4 examines the determinants and timing of settlements. Section 5 focuses on the terms of settlements and, in particular, on the prevalence of director turnover and the infrequent specification of direct actions. Section 6 examines the director changes on which settlement terms focus and analyzes their effects on board composition. Section 7 considers the stock market reactions that accompany the announcements of settlements, as well as the initial stock market reactions to the initiation of campaigns that ultimately end up in settlements. Section 8 focuses on the economic aftermath of settlements. In particular, we examine the changes in CEO turnover, shareholder payouts, likelihood of a strategic transaction, and operating performance that follow settlements. Section 8 also examines concerns about rent extraction by activists, and we find no evidence for such extraction. Finally, we present our conclusions in Section 9. The attached Appendix A provides a list of variable definitions, and Appendices B-1 through B-4 included in an online Data Appendix that is available on the NBER website provide additional relevant information about our dataset and settlement agreements. ${ }^{8}$

\section{Institutional background}

The first stage of an activist intervention occurs when an activist reveals its presence and possibly the changes it seeks to instigate at the company, e.g., to the target's board. This often happens when the activist files an SEC Schedule 13(d) upon crossing a 5\% ownership threshold of company shares outstanding. ${ }^{9}$ Objectives often proclaimed for the activism campaign include (i) maximizing shareholder value, which is the most common goal; (ii) changing capital structure, for example, by distributing excess cash to shareholders; (iii) changing business strategy, for example, by refocusing the company; (iv) sale of the target company; and/or (v) effecting governance changes, for example by replacing directors or the CEO. However, activists often do not disclose at the 13(d) stage what changes they will ultimately demand but rather keep their options open. Most activists do not initially take an adversarial position, hoping to be able to reach a cooperative outcome, but $25 \%$ of the activists in our sample (similar to the frequency reported

\footnotetext{
8 The Data Appendix is available at http://www.nber.org/data-appendix/w26171.

${ }^{9}$ The Schedule 13(d) filing is a mandatory filing under Section 13(d) of the Securities Exchange Act that requires investors to disclose within 10 days of acquisition of, or conversion into, more than $5 \%$ of any class of securities of a publicly traded company if they have an interest in influencing the control or the management of the company.
} 
in Brav, Jiang, Partnoy, and Thomas (2008) for an earlier sample) express an adversarial position when disclosing their presence.

How can an activist bring about changes it is seeking given that the power to set the course of the company is vested in the company's board of directors? One important route that has received significant attention is to win board seats in a proxy fight [see, Gantchev (2013), Fos and Tsoutsoura (2014), Fos and Jiang (2016), and Fos (2017)]. To do so, the activist needs to nominate director candidates, file a proxy statement, campaign for shareholder support, and win one or more board seats in the contested vote.

A settlement agreement offers a "cooperative" alternative to a contested vote. The settlement ends, at least for a specified time, the conflict between the two sides by requiring concessions on both sides. Because reaching an agreement with an activist is a material event, companies are required by the securities laws to disclose the existence and terms of a settlement agreement.

In such agreements, the most important and almost universal concession made by the activist is a "standstill" provision. Such a provision specifies a period during which the activist agrees to refrain from activities designed to influence the control or policies of the company. The termination of the standstill can be event-driven (i.e., it remains in effect until certain agreed-upon conditions are in effect) or time-driven (i.e., until a definite expiration date). There are two major types of standstill agreements: (i) a share ownership standstill which prohibits the activist from acquiring additional voting securities of the target company and, (ii) a corporate governance standstill which prohibits further activist activities such as seeking a merger, seeking additional board representation, or solicitation of the company's proxies.

In consideration for the activist's concessions, incumbent directors entering a settlement agreement can agree to take certain steps that would move the operations or strategy of the company in a direction favored by the activist. The incumbents have the power to agree to specified buybacks or special dividends, to explore a sale of the company or a recapitalization, or to replace the CEO. Alternatively, the incumbents can agree to make changes to board composition - adding specified new directors and/or avoiding re-nomination of specified incumbent directors - that could affect subsequent decisions concerning the company's operations and strategy. 


\section{Data and sample overview}

\subsection{Data sources}

We obtain stock returns from the Center for Research in Security Prices (CRSP) and accounting data from Compustat. The remaining data used in this study comes from various sources. First, data on activism events come from a dataset that is an extension of the sample studied in Brav, Jiang, Partnoy, and Thomas (2008). The events are identified mainly through Schedule 13(d) filings submitted to the SEC (accessible via the EDGAR system), which disclose beneficial ownership of 5\% or more of any class of publicly traded securities of a company where the investors intend to influence corporate policy or control. In putting together this dataset, Schedule 13(d) filings aiming at bankruptcy reorganization or distress investing, and those representing risk arbitrage after the announcements of mergers and acquisitions, were manually excluded because such events are not related to shareholder activism. To supplement Schedule 13(d) filings, news searches were conducted for activists who launch public activism with stock ownership below $5 \%$ at mid- to large-cap companies. We remove target firms whose CRSP common share codes differ from 10 or 11, the standard codes for common stock.

Our event sample period begins in 2000, because settlements were rare before 2000, and ends at the end of 2013. We follow the settlement outcomes to 2018. For each activist fund in our sample, we collect information on the number of past campaigns, past settlements, past proxy fights, past successful campaigns, and average market reaction to past campaign announcements, all measured over the five years prior to the start of the focal campaign.

Second, information on the existence of settlement agreements between activists and targets was obtained from FactSet's Shark Watch, Capital IQ Key Developments, and via news archive searches. We use these sources to determine, for each activism campaign launched between 2000 and 2013, whether a settlement agreement was reached by May 2018. Third, information on the contents of each settlement agreement was hand-collected from the public filings that targets and activists made and supplemented using a news archive search. ${ }^{10}$ Specifically, we collected information on the specific dates that settlement agreements were reached and publicly disclosed; the number of directors added and whether these directors were

\footnotetext{
${ }^{10}$ Appendix B-4 in the online Data Appendix provides an example of a representative settlement agreement.
} 
affiliated with the activist, unaffiliated but desired by the activist, or neither affiliated nor desired; the number of director departures stipulated in the agreement; whether the CEO has to leave the firm; whether the firm sells itself or a division, or whether the firm plans to engage in such actions; whether the board creates a "Strategic Transactions" committee; and whether the firm initiates or increases the scale of a buyback program.

Fourth, for each activism campaign, we also collected data on whether the activist filed proxy material and whether the proxy fight was settled (in which case we would already have collected the settlement agreement), withdrawn, or went to a vote. Fifth, information on director characteristics and turnover is collected from the Directors Database Archive, a product of Corporate Board Member Magazine, which provides quarterly snapshots of executives and directors of firms listed on the NYSE, NASDAQ, and AMEX going back to the year 2000 until year 2013. ${ }^{11}$ We supplement this data with information gathered from proxy filings and news searches to determine whether the new director is affiliated with the activist fund or, in the case of a director independent of the fund, at least favored by the fund. Sixth, director election voting outcomes were obtained from ISS Voting Analytics for the time period 2001 to 2018. This database covers the Russell 3000. We matched the names of the directors of our sample firms to the director names provided in ISS Voting Analytics by hand.

Seventh, information on target firm CEOs and their characteristics, and CEO turnover during activism campaigns is collected from the intersection of ExecuComp and Equilar for years 2000 to 2017. Eighth, for each of the activism campaigns in sample, we searched FactSet's Shark Watch, Capital IQ, Thomson Reuters' SDC, and news archives for privately negotiated share repurchase transactions between hedge fund activists and their target companies. Last, we collect information on target companies' share class structure, insider (board and management) ownership, and analyst coverage from Equilar, ISS, Thomson, FactSet Shark Watch, and IBES.

\footnotetext{
11 This database has recently been used in Brav, Jiang, Ma, and Tian (2018); Larcker, So, and Wang (2013); and Stuart and Yim (2010). Since Board Magazine was acquired by NYSE, it does not update or sell the Directors Database any longer, which means that the last year for which we have data on all the directors of companies listed on NYSE, NASDAQ, and AMEX is 2013.
} 


\subsection{Summary statistics}

Panel A of Table 1 reports the annual frequency of activist interventions, settlements, contested votes, and filings of proxy statements. Over the 14-year period 2000-2013, there were 3,012 hedge fund activism campaigns. Of these campaigns, 13\% (399 campaigns) resulted in a settlement agreement between the activist and the target company, while only 5\% (137 campaigns) resulted in a contested vote. The table indicates that settlements were rare during the beginning years of the 2000-2013 period, but the incidence of settlements has gone up considerably since then, increasing from 3\% for campaigns starting in 2000 to $21 \%$ for campaigns starting in 2013. By contrast, the incidence of contested votes has been relatively stable during the period we examine.

Panel B tabulates the frequency and outcome of proxy contests - defined as campaigns in which the activist filed a proxy statement - over time. Activists file proxy statements and thereby formally start a proxy contest in $12 \%$ of activism campaigns. Of the proxy contests initiated, $38 \%$ of them go all the way to a contested vote, $45 \%$ are settled, and $17 \%$ withdrawn. In untabulated analyses, we find that $44.4 \%$ of settlements are preceded by the activist filing proxy material. Thus, cases in which a proxy fight is formally initiated have a higher incidence of settlement than cases without a formal filing of a proxy statement, though activists still obtain the majority of settlements without having to formally file proxy material. In such cases, however, the background threat of pursuing a proxy fight might still play a role in inducing incumbent directors to agree to a settlement.

Appendices B-1 and B-2 in the online Data Appendix provide information about notable targets and activists. Appendix B-1 lists settlements related to activism campaigns launched between 2000 and 2013 regarding firms with market capitalization of $\$ 7$ billion and above, a total of 30 cases. The two largest target companies during the sample period were Microsoft, which settled with ValueAct in 2013, and PepsiCo, which settled with Trian Partners in 2015. Appendix B-2 lists the 30 activists that were involved in four or more settlements. The three activists that entered into the largest number of activist settlements were Carl Icahn (20 settlements), Ramius Capital (14 settlements), and ValueAct (13 settlements).

In the next section, we compare the characteristics of activist campaigns that result in a settlement, contested vote, or neither a settlement nor a contested vote. Table 2 reports the mean, 
median, and standard deviation for all independent variables in each of these three cases. For the sake of brevity, we will not discuss these descriptive statistics of table 2 here, but they will be informative when interpreting the results of the regressions analyses below.

\section{The determinants and timing of settlements}

\subsection{Settlement theory and tested hypotheses}

A settlement that averts a contested vote is akin to a settlement of litigation prior to going to a trial in court. The literature on the economics of litigation and settlement [see Spier (2007), Wickelgren (2013) and Daugherty and Reinganum (2017) for surveys] provides insights about why and when cases settle.

In particular, the litigation and settlement literature analyzes three potential outcomes of litigation situations: Such situations might go all the way to a court decision, might produce a settlement agreement that avoids a court decision, or might be "dropped" without either a settlement or a court decision. Similarly, we distinguish between three possible outcomes of activist campaigns and accordingly three groups of campaigns.

The first group comprises all campaigns that result in a settlement. The second group includes all campaigns that go all the way to a contested vote. The third group consists of all the campaigns that have no formalized outcome - that is, result in neither a settlement agreement nor a vote. Thus, the three outcomes we consider are: settlement; contested vote; and no settlement or contested vote.

The third group of campaigns - those without a formal resolution that have no settlement or contested vote - is likely heterogeneous. Some of these campaigns might be ones that the activist drops or aborts without achieving any of its objectives, say, because the activist concludes that it does not have sufficient support among shareholders to have a credible threat to win board seats that would enable the activist to extract a settlement or proceed to a contested vote. In some of these cases, however, the activist might be able to achieve or expect some change despite the lack of a formal resolution. To begin, the activist might hope that the kick-in-the-pants provided by the campaign will have a positive effect on future decisions of the incumbent directors and their responsiveness to shareholder interests. Furthermore, the incumbent directors might without any 
formal agreement take some action - say, announce an immediate buyback - that could make the activist sufficiently content to drop its campaign or, alternatively, could reduce the potential support that the activist might obtain among other shareholders and thus force the activist to abandon the campaign.

The making of such immediate concessions by the incumbent directors to avoid a contested vote or a formal settlement can be regarded as "informal settlement." However, such informal settlements are more limited in what they can provide the activist relative to the formal settlements on which we focus. Because the securities laws would require the incumbent directors to disclose any commitment that incumbent directors make to undertake some future action or any commitment that they obtain from the activist in return for actions they take, any situation with such commitments would be classified as a formal settlement in our dataset. Thus, informal settlements can involve changes that the incumbents take right away without accompanying commitments by the activist, but such informal settlements cannot include binding commitments by incumbent directors to take any future action or appointment of directors favored by the activist accompanied by a standstill or other commitment by the activist. Although informal settlements and the incumbent steps they consist of are thus more limited in the forms they can take, Section 8 presents evidence that campaigns without a settlement or a contested vote are still followed by an elevated probability that certain outcomes favored by activists will occur, and this evidence is consistent with the presence of informal settlements.

\subsection{The determinants of reaching a settlement or contested vote}

In examining the determinants of campaign outcomes, let us begin by discussing what will determine whether a campaign will result in a formal outcome - that is, a settlement agreement or a contested vote - or will be ended by the activist without such a formal outcome of either a settlement or a contested vote.

The literature on the economics of litigation and settlement indicates that cases will end with either a settlement or a court decision only if the plaintiff has sufficiently good odds of winning at trial (Bebchuk (1984), Spier (2007), Bebchuk and Klement (2012)). Without such odds, a rational plaintiff will not choose to bear the costs of pursuing the litigation all the way to a court decision, and a rational defendant will not agree to a settlement if the plaintiff's low odds of winning deprive it of a credible threat to pursue the litigation to a court decision. For activism 
campaigns, this economic logic implies that a campaign will be more likely to end with either a settlement or a contested vote when the activist's odds of winning seats in a contested vote are higher. Without sufficiently good odds for winning seats in a contested vote, a rational activist will be discouraged from bearing the costs of pursuing the proxy fights all the way to a contested vote, and rational incumbents will be less inclined to agree to a settlement with an activist that does not have a credible threat to win seats in a contested vote. Thus, we can put forward the following hypothesis:

Hypothesis H1: The likelihood of a campaign leading either to a settlement or a contested vote is positively related to the odds that the activist would prevail in a contested vote.

\subsection{The determinants of the choice between settlement and a contested vote}

We now turn to discuss, for the campaigns that result in a formal outcome of either a settlement agreement or a contested vote, what will determine whether there will be a settlement or a contested vote. The economic literature on settlement decision indicates that a driving force for settlement are the efficiency gains that could result - and could be shared by the two sides from avoiding the deadweight costs of trial. The larger these trial costs, the stronger the incentive to settle (Spier (2007), Prescott and Spier (2016)).

Similarly, in the case of an activism campaign, settlement would save the costs that the two sides would have to bear in the event of going all the way to a contested vote. Accordingly, the larger these costs, the stronger the incentive to have a settlement rather than a contested vote. The costs of a contested vote include the out-of-pocket costs of running a proxy fight all the way; a dissident's costs of running a proxy fight can easily rise to millions of dollars (Gantchev (2013)). ${ }^{12}$ However, for the incumbent directors and CEO, the most important source of costs might well be the expected reputational costs that going all the way to a contested vote might impose. Resisting an activist runs the risk of alienating other investors if the defense is perceived as unnecessary, and attacks on incumbent directors by the activist in a contest can produce substantial reputation costs for these directors, which the directors might have to bear irrespective of the outcome of the contest

\footnotetext{
${ }^{12}$ In the Trian Partners vs. DuPont proxy fight in 2015, the activist spent $\$ 8$ million launching the contest and DuPont spent $\$ 15$ million to defend. See, USA Today, 05/19/2015, "DuPont spent \$15M to keep activist investor off board." In the more recent Trian Partners vs. $P \& G$ proxy fight in 2017 the two sides were estimated to have spent at least $\$ 60$ million. See, New York Times, 10/16/2017, "Procter \& Gamble’s Count Shows How Close Proxy Vote Was.” While the dissident might already have incurred part of these costs at the time when the settlement is negotiated, many settlements specify that the activist is reimbursed part or all of its contest-related expenses.
} 
(Fos and Tsoutsoura (2014); Gow, Shin, and Srinivasan (2016)). Indeed, winning a heated proxy fight does not preserve the reputation of incumbent CEOs either. For example, after winning a proxy contest against Trian Partners in May 2018, DuPont CEO Ellen Kullman resigned only five months later.

Thus, the prospect of avoiding the expected reputational damage of a bruising proxy fight going all the way provides an incentive to have a settlement rather than a contested vote. Accordingly, we put forward the following hypothesis:

Hypothesis H2: The likelihood of an activism campaign leading to a settlement rather than a contested vote is positively related to incumbents' reputation concerns.

\subsection{Analysis of the determinants of settlements}

We test Hypotheses $\mathrm{H} 1$ and $\mathrm{H} 2$ using multinomial logit regressions that include three groups of campaigns as parallel outcomes: a) settled campaigns, b) campaigns that lead to a contested vote, and c) campaigns that lead neither to settlement nor to a contested vote. The relevant sample includes all activism campaigns (with non-missing information) launched by hedge funds over the period from 2000 to 2013.

We include the following explanatory variables listed and discussed below. The first set of variables, from the activist's stake to the target firm's past performance, serve as proxies for the activist's having good odds of winning a contested vote. The subsequent set of variables, from director age to analyst coverage, serve as proxies for the reputation concerns of the incumbents. ${ }^{13}$

The activist's stake: A larger stake for an activist is associated with an increased likelihood of success in a contested vote. The activist's stake provides it with votes on which it can always count in a proxy contest. In addition, because a large stake provides the activist with stronger incentives to increase value and can signal the activist's confidence in the prospects of value appreciation, having a large stake can help the activist obtain votes from other shareholders.

Insider Ownership: Conversely, when incumbents hold a larger stake in the firm, their chances of winning a potential proxy fight increases. Accordingly, large insider ownership is associated, other things equal, with lower odds for a victory by the activist in a contested vote.

\footnotetext{
${ }^{13}$ Even though untabulated analyses show that $44.4 \%$ of settlement agreements are preceded by the activist formally filing proxy material, we do not include such filings as determinants of the three groups (settlement, contested proxy vote, neither) because there is no variation in this variable for those campaigns that reach a contested vote.
} 
Target firm's share-class structure: The activist's chances in a contested vote are likely to be diminished when the target has a share structure with multiple classes. In such cases, the shares with superior voting rights are likely to be disproportionately held by insiders or shareholders affiliated with them and thus improve the incumbents' chances of prevailing in a contested vote.

The average market reaction to past campaign launches: The higher the stock price reaction to the initial announcement of activism, the higher the market's expectation of the benefits that the activism campaign could bring about and thus the greater the market's approval of the activism campaign. Thus, an activist track record of high initial market reactions to the activist's initiation of campaigns is likely to reflect the market's viewing the activist as capable of bringing about value increases. Such a market view is likely to increase the support that the activist would be able to obtain form other shareholders in a contested vote and thus improve the activist's chances in such a vote. ${ }^{14}$

Success in past engagements: Similarly, when an activist has a track record of successful past campaigns, the activist is more likely to have good relationships with, and enjoy a good reputation among, institutional investors. Thus, such a track record can be expected to be associated with improved chances in a contested vote.

Settlements in past engagements: Similarly, when an activist has a track record of obtaining settlements in past engagements, the activism is likely to have the characteristics that enabled it to have been viewed by the incumbents in such past engagements as having had good chances of success in a contested vote. Thus, such a track record is again likely to be associated, other things equal, with improved chances in a contested vote in the current engagement.

Proxy fights in past engagements: To have good chances in a contested vote, the activist must be open to, and have the necessary know-how and resources for, running a proxy fight. A track record of running proxy contests in past engagements implies that the activist is open to running a proxy fight and has experience in doing so.

Past firm performance: Poor past target firm performance (we measure performance using Tobin's Q, ROA, and past stock returns) has negative consequences for investors' perception of the incumbents. Thus, poor past performance of the target bolsters the odds of activist success in a proxy contest.

\footnotetext{
${ }^{14}$ We do not use the stock market reaction to the 13(d) filling in the considered campaign, but rather such stock price reactions to the initiation of earlier campaigns by the activist, due to endogeneity concerns.
} 
Directors Older than 70: Old incumbent directors - whether executives of the firm or outside directors - can be expected to have lower reputational concerns. Such directors are unlikely to be present in the market for directorships for a long time. All else equal, this shorter horizon of older directors thus decreases their reputation concerns.

Directors' Average Number of Directorships: Incumbent directors with more other directorships enjoy a higher reputation stock and have more seats to lose in case their reputation is tarnished. ${ }^{15}$ Fos and Tsoutsoura (2014) show that directors who are targets in a contested vote lose directorships they hold at other firms. Hence, holding directorships at other firms can be expected to be associated with higher reputational concerns for the directors.

CEO or Board Chair up for Election: The CEO and the chair of the board (if different from the $\mathrm{CEO}$ ) are key decision-makers on the response to activists. When the company has a staggered board, these individuals are not always up for election in the coming shareholder meeting. When either of these two important directors is up for election, success by the activist in a contested vote in the coming shareholder meeting might lead to the personal defeat and humiliation of these key decision-makers on the incumbent team. In such a case, these decision-makers will face the potential for a direct personal reputational cost that they would not similarly face if they were not up for reelection. Therefore, when the CEO or the board chair are up for election, the expected reputational costs pushing the key decision-makers toward settlement are likely to be stronger.

Analyst Coverage: Proxy contests that are more publicly visible are likely to have a more significant effect on the incumbents' reputation. Vega (2006) shows that the number of analysts following a company is strongly positively related to media coverage. Therefore, we use this variable as a proxy for the visibility - and hence potential reputational consequences - of a contested vote.

In Panel A of Table 3, we report the results of the multinomial models that test Hypothesis H1, which predicts that the credibility of the activist's threat is positively related to the likelihood of an activist campaign leading to a settlement or a contested vote (the first campaign subgroup) or a proxy contest (second subgroup), relative to neither of these two outcomes (third subgroup). ${ }^{16}$ The relative propensity to settlement (contested vote) relative to neither settlement nor proxy vote

\footnotetext{
${ }^{15}$ Jiang, Wan, and Zhao (2016) show that directors with higher stock of external reputation exhibit more reputation concerns.

${ }^{16}$ We do not include all the different proxies of the credibility of the activist's threat and for incumbents' reputation concerns in one regression because of multicollinearity concerns and because of the significant drop in sample size due to missing values.
} 
is shown in the odd-numbered (even-numbered) columns. The coefficients represent the change in the odds ratio that a campaign leads to a settlement (or proxy vote) relative to the base outcome, associated with a unit change in the independent variable.

Consistent with the hypothesis, we find that a number of proxies for the credibility of the activist's threat are related to the probabilities of a campaign leading either to settlement or proxy vote. Specifically, activists with a better reputation as measured by the market reaction to past campaign announcements and the number of past campaign successes are more likely to obtain a settlement or to go to a proxy vote. When controlling for these two proxies, activists with a large number of past campaigns are less likely to reach a settlement or a contested election, implying that the mere number of past engagements does not increase the credibility of the activist. ${ }^{17} \mathrm{~A}$ track record of reaching settlements in past campaigns is associated with a higher propensity to settle the focal campaign and a track record of running proxy fights in the past is related to a higher probability of reaching the proxy vote stage again.

Target firm ownership structure is also an important determinant of the credibility of the activist's threat and, in turn, whether campaigns lead to a settlement or a proxy vote. For campaigns with above-median activist ownership relative to campaigns with below-median activist stake size, the coefficient of 1.85 indicates that the odds ratio for settlement relative to the base outcome increases by $85 \%$. If a target firm has multiple share classes, the odds ratio of settlement decreases by $54 \%$. Furthermore, the extent of insider ownership is negatively related to the likelihood of settlement and proxy vote relative to the base state.

Depending on the specification, we find some support for weaker past target firm performance increasing the probabilities of settlement and vote. This finding is consistent with weaker performance increasing the credibility of the activist's threat, potentially because of the dissatisfaction of other shareholders.

Taken together, these results are consistent with Hypothesis H1 and imply that activist reputation, target firm ownership structure, and, to a lesser extent, target firm performance play a

\footnotetext{
${ }^{17}$ One fund in our sample, GAMCO, has close to 100 campaigns. Even after dropping campaigns with more than 29 past campaigns (which is the $90^{\text {th }}$ percentile) the number of past campaigns remain negatively and significantly related to the probability that the focal campaign leads to a settlement. When we exclude the other activist reputation proxies, the number of past campaigns remains negatively related to the probability that the current campaign leads to a settlement or proxy vote, albeit insignificantly so. Given the potential multicollinearity of the different activist reputation proxies, we do not include all of them in the same regression.
} 
key role in determining the credibility of the activist's threat, which in turn affects the probabilities of the engagement ending without either a settlement or a contested vote.

We also examine whether and how proxies for incumbents' reputation concerns are related to the probabilities of settlement and contested election vis-à-vis the base outcome. The results are presented in Panel B of Table 3. We find that boards whose directors and independent directors hold a larger amount of board positions are less likely to settle while boards with a larger number of old (independent) directors are more likely to participate in contested elections. The latter result is consistent with reputation being less of a concern among older directors. In addition, we find that the relative likelihood of settlement increases when the board chair is up for election and when the campaign is more visible due to higher analyst coverage.

Table 4 completes the test of multinomial regressions to test Hypothesis $\mathrm{H} 2$, which predicts that the probability of an activism campaign leading to a settlement vis-à-vis a contested proxy vote increases in incumbents' reputation concerns. Specifically, Table 4 compares the likelihood of settlement to that of the base outcome of a contested proxy vote. We find some support for Hypothesis H2, which predicts that incumbents' reputation concerns are positively related to the relative likelihood of settlement.

In particular, the odds ratio of settlement vis-à-vis contested proxy vote is 2.9 times as high when the board chair is up for election, consistent with reputation concerns being particularly strong for the chairs of target firm boards. When the activism campaign is more visible the relative likelihood of settlement also increases, consistent with the public visibility of a potential proxy fight increasing incumbents' reputation concerns. While these findings support Hypothesis H2, we find no evidence that the other proxies for incumbents' reputation concerns, the number of old directors, the average number of directors' outside board positions, and whether the CEO is up for election, are associated with the more settlements versus contested votes. ${ }^{18}$

In Table 4, we also examine whether the proxies for the credibility of the activist's threat are related to the relative likelihood of settlement. We find that higher market reactions to the activist's past campaigns and the number of past proxy fights favor contested votes while the number of past settlements and above-median activist ownership favor settlement. We find no consistent pattern for target firm performance.

\footnotetext{
${ }^{18}$ In addition to proxying for incumbents' reputation concerns, these measures might also capture the ability of these directors and boards to monitor the CEO. For example, directors with a large number of directorships might be too "busy" to monitor properly (Fich and Shivdasani (2006); Falato, Kadyrzhanova, and Lel (2014)).
} 


\subsection{The timing of settlements}

Having examined the determinants of settlements, we would like to conclude this section by considering the timing of settlements. The literature on the economics of settlement and litigation has shown that divergent expectations regarding the outcome of trial can be an impediment to obtaining a settlement [see, e.g., Shavell (1982)]. When the parties have symmetric expectations regarding the expected outcome of trial, there would always be a range of settlements that would be viewed by both parties as superior to trial. However, divergence of expectations

might sometimes narrow or eliminate the range of settlements that would be viewed as superior to trial by both parties. As a result, the discovery process and the arrival of information as trial nears can facilitate an out-of-court settlement.

Similarly, for the case of an activist campaign, divergence of expectations between the two sides about the expected effect of a contested vote can impede the reaching of a settlement. However, as the two sides get closer to the company's shareholder meeting, the information the two sides get from their proxy solicitors and from their communications with institutional investors can be expected to provide them with better ability to predict the expected outcome of a contested vote and to narrow any widely divergent expectations regarding this expected outcome. Accordingly, with respect to the timing of settlements, we hypothesize that that settlements are more likely to occur closer to the shareholder meeting in which a contested vote would otherwise take place rather than earlier on.

To test this hypothesis, we gather information about the timing of settlement agreements within the period between the start of the activist campaign and the company's first subsequent annual shareholder meeting (AGM) in which a contested vote could take place. For the 211 settlements that occur within this period, we find that the length of time between campaign start and the subsequent shareholder meeting has a mean (median) of 188 days (184 days), slightly more than six months. Consistent with settlements being more likely to occur during the second half of this period rather than the first part, about $70 \%$ of settlements take place after the mid-point of the period between campaign launch and AGM; and the ratio of (i) the time between the settlement and the AGM to (ii) the time between campaign launch and AGM has a mean (median) value of is $0.38(0.35)$.

Furthermore, when we divide the period between campaign launch and the AGM into three equal-length sub-periods, we find that about $47 \%$ of settlements fall during the third sub-period, 
and about $84 \%$ fall during the second and third equal-length sub-periods, with only about $16 \%$ of settlements falling into the first equal-length period. We reject the uniform-distribution null hypothesis of one-third of the settlements falling proportionately in each sub-period with a ChiSquare test (test statistic is 31.91, p-value below 0.001).

\section{Settlement terms: The focus on board composition}

Activist hedge funds are ultimately interested in implementing operational or leadership changes that they believe would substantially increase the value of their shares. Operational changes include a major transaction such as a divestiture of a peripheral division, and sale of the company or a major part of its assets. Leadership changes often focus on replacing the CEO with another individual who would be expected to perform better or change the company's strategic direction.

However, rather than a settlement agreement that requires such specific changes - that is, that specifies some direct action the board committed to take - the parties can make an agreement that focuses on changing some of the individuals on the board of directors and leaves the possibility of making operational and leadership changes to decisions by the board down the road. For example, in the Sotheby's case, Third Point campaigned against the CEO and the strategic plan he was pursuing. The settlement agreement signed in May 2014 provided board seats for Third Point founder Dan Loeb and two of his associates but kept Sotheby's CEO William Ruprecht in place. Subsequently, in November 2014, Ruprecht stepped down and Dan Loeb handpicked Tad Smith from Madison Square Garden for replacement.

In this Section, we show that such cases should be expected, and indeed are, most common. We begin with a theoretical discussion, putting forward three considerations that can be expected, individually or in combination, to lead parties to focus on board turnover and avoid inclusion of direct action terms. We then proceed to look at the evidence and show that it is consistent with the theory. 


\subsection{Theory}

\subsubsection{Incomplete contracting}

The first reason for why we do not expect settlement agreements to contract on operational or leadership changes relates to the theory of incomplete contracting developed over the years by Oliver Hart and his co-authors, which is discussed in detail in Hart's Nobel Prize Lecture on the subject (Hart (2017)). ${ }^{19}$ The incomplete contracting paradigm focuses on situations in which contracting parties have primarily an interest in some subsequent ex post actions or outcomes, but contracting on such ex post actions is impossible due to the costs or limits on what courts can or will verify and enforce ex post [see Aghion and Bolton (1992) for a well-known application of the insights of incomplete contracting to explain financial contracting choices that focus on corporate influence and control arrangements].

We argue that our setting is one in which directly contracting on the ex post operational changes sought by the activists is often not feasible. Consider a hedge fund activist that would like to have a target sold. If a well-specified offer from an outside buyer is not yet available, the settlement agreement cannot require the acceptance of a specific sale offer, and requiring the company to be sold later on would be impractical. To begin, how and whether a sale should be pursued would depend on contingencies that would be difficult or impossible for a court to verify and enforce. When and at what price it would be optimal to sell would depend on what offers a search for buyers would generate and what would take place in the market in the meantime. Furthermore, and relatedly, corporate law rules preclude directors from making a binding and irreversible commitment to recommend a sale without leaving a "fiduciary out" that would allow them to avoid a sale if doing so would in their judgment be best for shareholders.

To be sure, incumbent directors could commit to establishing a board committee to explore a sale. However, as long as the team of incumbent directors does not change, the activist could well be reasonably concerned that, not having been interested in a sale earlier, the incumbents could explore the option perfunctorily rather than wholeheartedly and that a sale would remain unlikely. Thus, to increase the likelihood that the company will effectively pursue a sale, it would

\footnotetext{
${ }^{19}$ We are grateful to Oliver Hart for a detailed discussion of the applicability of the incomplete contracting paradigm to our setting, and the consistency of our findings with an incomplete contracting view.
} 
be best for the activist to add to the board directors that the activist believes would be open to or interested in a value-enhancing sale.

Similarly, consider a case in which the hedge fund activist is not merely interested in firing the current CEO but also in the quality and fit of the CEO's successor. Such a successor might not be readily available at the time the settlement agreement and, given that courts would have difficulty verifying the quality and fit of a chosen CEO versus alternatives, it would not be feasible for the activist to secure the high-quality choice the activist seeks by requiring such a choice in the settlement agreement. Thus, to increase the likelihood that the company will down the road choose the successor CEO in the manner sought by the hedge fund activist, it would be best for the activist to add to the board directors that the activist believes would be likely to push for such a CEO choice.

We note that while some changes sought by activists are difficult or impossible to contract, others are not. In particular, including the firing of the CEO in the settlement agreement is not precluded by incomplete contracting considerations. However, there are two other considerations that might keep such changes out of settlement agreements.

\subsubsection{Face-saving benefits and reputational concerns}

Another reason for keeping operational or leadership changes out of settlement agreements relates to incumbents' reputation concerns. Specifically, postponing operational and leadership changes until after the settlement can provide face-saving benefits to the incumbent $\mathrm{CEO}$ and directors, impose lower reputational costs on them, and thus increase the parties' joint surplus from making an agreement. For example, if the settlement agreement were to include a provision requiring the departure of a $\mathrm{CEO}$, the CEO's being fired would be salient and the CEO would bear substantial reputational costs. Furthermore, in this case, the incumbent directors might be viewed as "throwing the CEO under the bus," and thus would bear reputational costs as well.

By contrast, if the CEO were to announce her departure several months down the road after the settlement agreement, the departure can be attributed to changes in the personal circumstances of the CEO and not be unambiguously viewed as a firing. For example, in the Sotheby's case, the hedge fund activist strongly campaigned against the CEO but accepted a settlement agreement that did not include the CEO's removal. Six months after the settlement the company announced that 
the CEO was stepping down "by mutual agreement," and the lead independent director lavishly praised the departing CEO, stating that “[m]y fellow Directors and I salute Bill's unwavering dedication and the many significant contributions he has made to Sotheby's for more than three decades."

Similarly, if the incumbent directors accept a settlement provision requiring the sale of a division that they have been resisting during the campaign, they might be viewed as capitulating under pressure to accept a strategy they do not favor. By contrast, if such a change is made by the new board several months down the road, it can be presented as a consequence of discussions on the board, and the resulting development of views, or a change in the company's circumstances.

Taken together, incumbents' reputation concerns during activism campaigns represent another reason for why settlements are unlikely to contract on CEO turnover or operational changes. In addition, the presence of reputation concerns also suggests that incumbent directors should be hesitant to agree to settlement terms that specify the immediate departure of some of them. Allowing incumbent directors to retire several months or even years following the settlement is more face-saving to them than their departure being stipulated under activist pressure in the settlement agreement.

\subsubsection{Asymmetric information}

Thus far we discussed situations in which the activist is certain that it prefers a certain change. However, as is emphasized and analyzed by the model of Corum (2018), there might be situations in which the activist recognizes that the board of directors has private information that would be useful for evaluating whether a given change would be value-enhancing.

Suppose that the board of directors has private information that is useful for assessing whether the incumbent CEO is still the best match for the target firm or whether a subsidiary of the firm would be worth more if sold or spun off. In this case, the best course of action for the hedge fund activist might be to defer the decision on the change, have new directors whose judgment the activist respects join the board and obtain the private information possessed by the board, and have these directors participate in making a decision down the road regarding the CEO or the spin-off. 


\subsection{Evidence}

\subsubsection{Board turnover v. direct action}

The discussion in Section 5.1 suggests that, due to incomplete contracting, reputation concerns of incumbent directors, and informational asymmetry between incumbents and the activist, settlements commonly will not contract on direct actions such as CEO turnover or the sale of the firm. Instead, settlements should commonly be expected to contract on the identity of the agents that may choose among those actions down the road. The goal of the activist is to introduce into the boardroom individuals that are expected or likely to be open to the type of changes that the activist seeks. Following the theory in Section 5.1, we therefore test the following hypothesis regarding the frequency of settlements that specify board turnover and direct actions.

Hypothesis H3: The proportion of settlements specifying director turnover is higher than the proportion of settlements specifying direct actions such as CEO turnover of strategic transactions.

Panel A of Table 5 reports the frequency of board turnover and direct actions specified in 399 settlement agreements reached in campaigns that were launched between 2000 and 2013. Settlements on average are significantly more likely to stipulate board turnover $(85.71 \%$ of settlements) than direct actions such as the sale or merger of the firm or of parts of the firm or CEO turnover $(8.27 \%$ of settlements). This difference is statistically significant at the $0.1 \%$ level. Furthermore, the proportion of settlements that only specify board turnover and no actions $(79.95 \%)$ is also significantly larger than the proportion of settlements that only specify actions $(2.51 \%)$.

Panel B of Table 5 shows that the actions that settlements do stipulate include CEO departure $(5.3 \%)$, sale or merger of the firm (2.5\%), and sale of a part of the firm's assets $(0.5 \%)$. Other settlement terms that are more difficult to classify as actions include the formation of strategic transaction committees (5.76\%), the 'exploration of strategic alternatives' $(4.76 \%)$, and the announcement of new or increased buyback programs $(5.26 \%) .{ }^{20}$ Taken together, the evidence

\footnotetext{
20 The creation of a Strategic Transaction Committee and the claim to 'explore strategic alternatives' do not represent actions as they may or may not result in a strategic transaction. Similarly, announcements about buyback programs are difficult to classify because firms have significant discretion about whether and when to execute and complete buyback programs.
} 
that presented in Table 5 indicates that, consistent with Hypothesis H3, activists use settlement negotiations to contract for board changes rather than direct actions.

\subsubsection{Face-saving benefits and reputational concerns}

The discussion of incomplete contracting in Section 5.1 indicates that the nature of some outcomes desired by activists, such as selling the firm down the road to a buyer yet to be identified, is not practically contractible. However, some other outcomes desired by activists, such as replacement of the $\mathrm{CEO}$, can be contracted upon. We therefore now turn to examine whether the two other factors discussed in section 5.1., face-saving benefits and informational asymmetry, contribute to the infrequent incorporation of direct actions in settlement terms.

Beginning with the role of face-saving considerations, we begin by observing patterns suggesting that incumbent directors are sensitive to face-saving considerations. Panel B of Table 5 shows that $84 \%$ of settlements result in the appointment of new directors while director departures only occur in $37.6 \%$ of cases. Similarly, while the average number of new directors added in a settlement is 1.79 , the average number of departures is only 0.87 . This difference is statistically significant at the $0.1 \%$ level.

Figure 1 plots the number of director additions and director departures in the 11 years around settlement agreements and provides additional evidence that the rate of director addition is significantly higher than the rate of director departure in the year of settlement. In addition, this figure shows that while the addition rate reverts back to normal levels in the year following the settlement, the departure rate remains high in the ensuing years, which suggests that many incumbent directors are allowed to depart quietly in the years following the settlement rather than being publicly ousted via the settlement agreement.

Panel $\mathrm{C}$ of Table 5 shows that, for settlements that specify 1, 2, 3, 4, or more director additions, the average number of director departures is consistently below the number of additions. Consistent with the patterns in Figure 1, this leads to statistically significant temporary increases in the board size of target firms. In unreported analyses, we find consistent evidence showing that target firm board size increases in the year of the settlement and then gradually reverts back to normal levels in the ensuing years. These findings suggest that the low rate of director departures 
(relative to director additions) specified in the settlement is not driven by an increase of the optimal board size of these firms.

While the above evidence indicates that reputational considerations are present in the settlements sample, there likely exists some variation in reputation concerns among incumbent directors and CEOs. Specifically, reputational concerns should be weaker if directors and CEOs have already reached customary retirement age and thus do not expect to participate in the labor market much longer. Therefore, we test the following hypotheses:

Hypothesis H4: The probability of a settlement specifying director departure or CEO departure is negatively related to the strength of incumbent directors' and CEOs' reputation concerns.

Panel A of Table 6 tests this hypothesis. The dependent variables identify settlement terms that are most costly to incumbents' reputation, namely CEO departure and director departure. The independent variables are proxies for directors' and CEOs' reputation concerns related to whether they have reached customary retirement age. We find that the higher the number of septuagenarian directors or outside directors on the board, the greater the probability of settlement terms specifying director departure and the higher the number of director departures. For example, for each director on the board who is older than 70 years, the likelihood of director departure increases by 8.3 percentage points. We also find that if the CEO is close to retirement (above 62 years of age), the probability of settlement terms specifying CEO departure increases by 7.7 percentage points, an effect that is economically large though not statistically significant. ${ }^{21}$

These results are consistent with incumbents the parties' being more likely to incorporate departures directly in the settlement terms when reputational concerns, and thus the face-saving benefits from delaying departures, are greater. ${ }^{22}$ Thus, the results are consistent with Hypothesis H4. However, we acknowledge that these results are also subject to the alternative explanation that the identified positive relation between director/CEO age and immediate (i.e. stipulated in settlement) director/CEO departures because the presence of old directors/CEOs implies stronger

\footnotetext{
21 The CEO age cutoff is similar to Kaplan and Minton (2012) and Jenter and Lewellen (2015).

${ }^{22} \mathrm{We}$ do not find evidence that other variables which could be regarded as a proxies for incumbents' reputation concerns, such as the aggregate number of incumbents' directorships and analyst coverage, are not associated with settlement terms. Also, we find no evidence that, whereas a board with its chair up for re-election is more likely to enter a settlement with the activist (Table 4), having the chair up for re-election is not associated with the nature of settlement terms.
} 
entrenchment which the activist wishes to break up right away in the settlement rather than later. These two different explanations are difficult to disentangle.

\subsubsection{Asymmetric information}

Finally, we turn to examine whether the informational asymmetry between incumbents and activists also contributes to the infrequent incorporation of direct actions among settlement terms. As is suggested by the discussion in section 5.1.3 and the model of Corum (2018), informational asymmetry can prevent the activist from fully understanding whether certain outcomes would indeed be value-enhancing and thus to prefer that a decision regarding them be deferred. Below we investigate whether the infrequent incorporation of direct actions in settlement terms is at least partly due to such informational asymmetry.

To this end, we exploit the fact that information asymmetry between incumbents and the activist likely differs in the cross-section of activism campaigns. Given this variation, the informational asymmetry explanation suggests the following hypothesis:

Hypothesis H5: The probability of settlements specifying direct actions is negatively related to the extent of information asymmetry between incumbents and the activist.

We follow prior literature [see, e.g., Minton and Schrand (1999) and Zhang (2006)] in using cash flow volatility as a proxy for informational asymmetry. In Panel B of Table 6, the independent variable of interest, serving as a proxy for information asymmetry between incumbents and the activist, is the firm's cash flow volatility over the past five years. The dependent variable is an indicator for whether the settlement terms include direct actions whose value consequences can be better assessed using private information possessed by the board, such as the sale or merger of the firm, the sale of parts of the firm's assets, and CEO departure. Across several specifications, we find a negative association between our proxy for informational asymmetry and the likelihood that settlement terms specify such direct actions. These finding are consistent with Hypothesis H5 and thus the predictions suggested by the informational asymmetry factor and the model of Corum (2018). 


\section{Effects on Board Composition}

In the preceding Section, we argued that settlement terms are likely to focus commonly on director turnover rather than the type of leadership and operational changes which activists ultimately seek to obtain to enhance share value, and we provided evidence consistent with this hypothesis. In this Section, we investigate the board composition changes brought about by settlements. Among other things, we analyze the extent to which the board turnover produced by settlements is abnormal; the type of directors that settlements introduce; the post-settlement board turnover changes that follow to reverse the temporary increase in board size that settlements often produce; and whether settlements lead to an improvement in board monitoring capabilities as evidenced by director characteristics and shareholder votes in director elections.

\subsection{Methodology}

To verify that the extent of board turnover specified in the settlement agreement is indeed abnormal, and to examine whether settlement agreements are followed by changes in board composition, CEO turnover, and operational changes, we need to find control firms with similar ex ante characteristics as settlement firms prior to the settlement. In addition, we want to control for any potential relation between the initial activist intervention and board turnover as this relation is distinct from the effect of the settlement. Finally, we also want to filter out the relation between contested proxy votes and board turnover. Thus, our analyses of the consequences of settlement include six groups, three treatment groups and three matched control groups, as described below.

The first treatment group is the subsample of campaigns that leads to a settlement and the year of treatment is the year in which the settlement agreement is reached. The corresponding control group consists of untargeted firms and is matched based on the year of the settlement. This implies that treated and control firms have similar observable characteristics during the years leading up to the settlement year. The second treatment group consists of the subsample of campaigns that neither experience a settlement nor a contested proxy vote. The treatment year is the year of the initial intervention and untargeted control firms are matched based on that year. The third treatment group includes campaigns that lead to a contested vote. The treatment year is the year in which the proxy fight is announced, and we find a third control group of untargeted firms based on that year. 
We use three propensity-score matching iterations to find control firms for the three treatment groups. The variables that we include in the propensity score matching regressions are

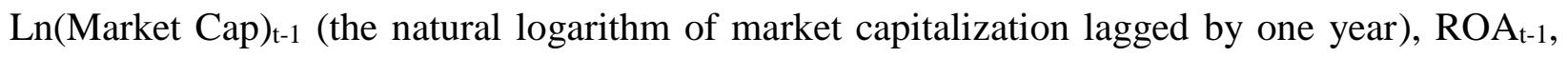
$\mathrm{ROA}_{\mathrm{t}-3}$, Tobin's $\mathrm{Q}_{\mathrm{t}-1}$, and Tobin's $\mathrm{Q}_{\mathrm{t}-3}$, based on the earlier findings that small and underperforming firms are more likely to be targeted (Brav et al. (2008)) while, among the population of target firms, large and underperforming firms are more likely to settle or be subject to a contested vote (see Table 3). Then we match treated and control firms on the resulting propensity score. For each firm in the three control groups, we require the placebo year to be the same year as the treatment year and we require the matched firm to be in the same two-digit SIC industry to control for unobserved industry trends and macro-economic conditions.

For each treated firm, we select at most five matched control firms (without replacement) but we delete treatment-control pairs that belong to the worst $5 \%$ of matches with respect to the absolute distance between the two propensity scores. Appendix B-3 in the Data Appendix shows that covariate balance is satisfied in all 21 mean-comparison tests and pre-event parallel trends tests in ROA and Tobin's Q between treated and control firms. To build the final dataset, we collect data on dependent and independent variables for the 11 years around the treatment year for treated firms, or the matched placebo year for control firms.

For each outcome variable, we present three difference-in-differences regression specifications. We cluster standard errors by firm across all specifications. The first estimates the difference in the outcome variable from pre to post settlement year relative to the difference in the outcome variable from pre to post placebo year.

$$
Y_{i, t}=\alpha_{i}+\alpha_{t}+\beta \cdot d[s+k]_{i, t}+\gamma \cdot \text { Settlement } \cdot d[s+k]_{i, t}+\varepsilon_{i, t}
$$

where $\alpha_{i}$ and $\alpha_{t}$ represent firm and year fixed effects, respectively. $d[s+k]$ with $-5 \leq k \leq 5$ is a set of indicator variables for the year relative to the settlement or placebo year. Year $s-1$ is the omitted base year. Thus, $d[s+k]$ capture the difference in the level of the dependent variable among control firms between years $s-1$ and $s+k$. In this model, the level effect associated with the Settlement firms is subsumed by the firm fixed effects. The dummies Settlement $\cdot d[s+k]$ capture the change from $s-1$ to $s+k$ in the difference in the dependent variable between firms that settle and control firms. 
The approach summarized in equation (1) only relies on campaigns that were settled and matched control firms, and therefore does not control for the potential association between the initial activist intervention and the dependent variable. To mitigate concerns that such association confounds the results, we use a second regression specification in which we include the second treatment group, i.e., target firms that neither reach a settlement nor a proxy vote and their matched control firms. These firms were matched on the year of initial intervention. To further control for the potential confounding effect of the initial intervention among settling firms and their matched control firms, we identify the year of the initial intervention for firms that reach a settlement and assign that year to their matched control firms as a placebo intervention year. Then we estimate equation (2).

$$
\begin{aligned}
Y_{i, t} & =\alpha_{i}+\alpha_{t}+\delta \cdot \text { Settlement }_{i}+\beta \cdot d[s+k]_{i, t}+\gamma \cdot \text { Settlement } \cdot d[s+k]_{i, t} \\
& +\zeta \cdot d[t+k]_{i, t}+\eta \cdot \text { Activism } \cdot d[t+k]_{i, t}+\varepsilon_{i, t}
\end{aligned}
$$

where $d[t+k]$ with $-5 \leq k \leq 5$ is a set of indicator variables for the year relative to the initial intervention year or relative to the placebo year. As before, year $t-1$ is the omitted base year. The coefficient of Settlement captures the difference in the dependent variable between target firms that settle and matched control firms in year $s-1$. The level effect of firms treated by Activism is subsumed by the firm fixed effects. The dummies Activism $\cdot d[t+k]$ capture the change from $t-1$ to $t+k$ in the difference in the dependent variable between target firms and control firms. The advantages of this matching approach are that we can control for any association between the initial intervention and the outcome variables such that the difference-in-differences estimates around the settlement year capture the effect of settlement over and above the effect of the initial intervention. In the final model (3) we further add firms that experience a voted contest, as well as their matched control firms, to be able to compare the changes in the dependent variables around settlement to the changes around voted contests.

$$
\begin{aligned}
Y_{i, t} & =\alpha_{i}+\alpha_{t}+\delta \cdot \text { Settlement }_{i}+\beta \cdot d[s+k]_{i, t}+\gamma \cdot \text { Settlement } \cdot d[s+k]_{i, t} \\
& +\zeta \cdot d[t+k]_{i, t}+\eta \cdot \text { Activism }_{i} \cdot d[t+k]_{i, t} \\
& +\theta \cdot \text { VotedContest }_{i}+\lambda \cdot d[c+k]_{i, t}+\mu \cdot \text { VotedContest } \cdot d[c+k]_{i, t}+\varepsilon_{i, t}
\end{aligned}
$$

where $d[c+k]$ with $-5 \leq k \leq 5$ is a set of indicator variables for the year relative to the announcement year of a proxy fight that went to a vote or relative to the placebo year. Year $c-1$ is the omitted base year. The coefficient of VotedContest captures the difference in the dependent variable 
between target firms that experience a proxy fight and matched control firms in year $c-1$. The dummies VotedContest $\cdot d[c+k]$ capture the change from $c-1$ to $c+k$ in the difference in the dependent variable between firms that experience a contested vote and control firms.

\subsection{Abnormal board turnover}

Table 5, discussed above, shows that $84 \%$ of settlements stipulate director additions and $37.6 \%$ director departures. Figure 1, which plots the annual number of director additions and departures for settlement firms and matched control firms, provides a first indication that the amount of board turnover specified in these settlement agreements is indeed abnormal. We observe no difference between treatment and control firms before the settlement but a peak in both the addition and departure of directors among treated firms in the year of the settlements. The average abnormal number of director additions (departures), i.e., in excess of control firms, is 1.43 (0.85) during the year of the settlement.

This asymmetry in the addition vs. departure implies that the boards of settlement firms expand around the year of settlement. In untabulated analyses we find that the average board size increases from about 8.3 directors prior to the settlement to a peak of 9.1 the year after the settlement is reached. Following the year of the settlement or placebo, treated and control firms show similar trends in board additions, but settlement firms experience significantly higher board departures than control firms, so that treated firms' board size gradually adjusts to pre-settlement levels. These patterns are consistent with incumbent directors being allowed to "retire" from target firm boards in a face-saving way in the years following settlement agreements.

Table 7 maps the pattern shown in Figure 1 into a linear regression framework. In this table, the dependent variables are Number of Director Additions and Number of Director Departures. The observations are recorded at the firm-year level for all target and control firms covered in the Board Magazine Directors Database universe between 2000 and 2013. The coefficients on Settlement $\cdot d[s+k]$ represent the difference-in-differences estimates and clearly confirm the patterns in Figure 1: Both additions and departures spike in the year of the settlement relative to the year before, with an average of 1.3 to 1.4 new directors and 0.74 to 0.84 departing ones. These estimates represent an "abnormal" increase in board turnover relative to matched control firm years and are statistically significant. We continue to find strong abnormal increase in board turnover among settlement firms when we use year $s-2$ as the benchmark period instead 
of year $s-1$ as reported at the bottom of Table 7. Also consistent with Figure 1, firms that eventually settle do not experience a higher rate of board turnover prior to the settlement compared to control firms. We find some director additions in the year following settlement and continue to observe abnormally high numbers of director departures until two years after settlement. This result further supports the claim that settlement agreements allow incumbent directors to exit in a face-saving way in the months or even years following the settlement.

The regression framework allows us to explore related effects. In columns 2, 3, 5, and 6, we include indicators capturing abnormal changes in board turnover around the year of the initial activist intervention, which typically takes place one year prior to the year of settlement if there is one. Table 7 indicates that the initial intervention per se is associated with abnormal increases in board turnover but again in an asymmetric way: while we observe abnormal increases in new director additions in the year of campaign launch, $t+1$, and $t+2$, we find evidence of abnormal director departures only in year $t+2$. By controlling for the time window surrounding the initial activist intervention, we effectively disaggregate total board turnover following settlements into turnover associated with the initial activist intervention and the incremental turnover that is directly related to the settlement. Importantly, estimates of the increase in board turnover around the year of the settlement remain statistically and economically significant after controlling for the changes that are associated with the initial activist engagement.

Finally, columns 3 and 6 document evidence for abnormal board turnover around contested proxy votes. We find 1.4 new director additions above the normal level in the first year following the proxy fight announcement and between 0.3 and 1.1 abnormal director departures in years $c$, $c+1$, and $c+2$. These magnitudes suggest that settlements potentially provide a less costly avenue to achieve a similar level of board turnover as proxy fights do. Unlike settlements and initial activism campaign launches, proxy fights are preceded by an abnormal amount of director departures three years prior to contest announcement.

\subsection{Activist directors}

Having established the magnitude of board turnover following activist engagements in general, and settlement agreements in particular, we now turn to the characteristics of the directors that are added and removed. We provide evidence that activism campaigns are indeed associated with the addition of new directors and that settlements are associated with the appointment of more 
pro-activist directors than campaigns not leading to a settlement. To examine whether activists indeed influence the appointment of directors, we proxy for the relationship between activists and directors by separating newly-added directors into three mutually-exclusive categories: (i) directors that are affiliated with the activist fund; (ii) directors that are not affiliated with but (publicly) favored by the activist; and (iii) other directors.

The status of "favored but not affiliated" is based on manual classification from proxy materials and news searches. The dummy variable is coded as one for directors who are not employees of the fund but there is evidence of any of the following: a) they are described in media accounts as being selected or desired by the fund; b) they appear, on the fund's proxy material, as directors that the fund would like to choose for replacements in case some directors are unable to continue serving on the board; c) they have to resign if the fund falls below a certain ownership threshold; or d) they have previously been appointed by the fund during other campaigns.

Panel B of Table 5 already provides some indication that hedge fund activists are indeed involved in the selection of the new directors who join target firm boards following settlement negotiations. In $51.9 \%$ of the settlements, directors affiliated with the activist fund join the board, and in $52.4 \%$ of cases the added directors are favored by, though not affiliated with, the activists. The average number of activist-affiliated (activist-desired) directors added is 0.65 (0.94).

In this Section, we examine the activist's influence on the choice of new directors more thoroughly. Table 8 documents the likelihood that a new director who is added to the board following the initial intervention, settlement or proxy contest is activist-affiliated, activist favored but unaffiliated, or neither of these two. We include new directors who are added within five years following the initial intervention, up to 2013, which is the year in which we lose access to the Board Magazine data base. Activists are unlikely to place directors on the boards of untargeted companies so Table 8 only includes target firm-years post intervention and no matched control firms. We treat any of the years 3, 4, and 5 following the initial intervention as the omitted base years if they do not overlap with the three-year periods following settlements or proxy fight announcements.

The results provide strong support for activists' role in the selection of new directors. In the year of settlement, the likelihood that a new director is affiliated with the activist, is between 18.6 and 24 percentage points higher than in years $t+3$ through $t+5$ following the initial 
intervention. In addition, the probability of new directors being unaffiliated with but desired by the activist increases by 19 and 30 percentage points, while the likelihood that a new director is not desired by the activist is between 44 to 50 percentage points lower. We find some weak evidence that the number of activist affiliated new directors is abnormally low in year $s+2$ following the settlement, likely driven by the observation in Table 7 that by $s+2$, the settlement has no effect anymore on the number of new board additions. We find that the abnormally high number of newly-added unaffiliated-but-desired directors and other directors continues until year $s+1$ but with lower magnitude.

These results hold after controlling for dummies that capture the type of director additions following the initial intervention and following proxy contest announcements. For the first three years following the initial intervention, we find increased probabilities of new activist-affiliated directors and activist-desired directors and fewer other directors added to the board, although the magnitudes are lower than those observed during the settlement year. Similarly, we find a higher likelihood of activist-affiliated and activist-desired directors, and lower other directors, added to target firm boards in the year of and the year following proxy contest announcement.

Though the board turnover around initial intervention, during proxy fights, and following settlement is statistically significant and economically meaningful, it reflects changes that are in most cases, strict minority relative to the full size of a board (typically $8-9$ directors). The activist's strategy is thus about influence rather than control of the board. The activists, even if successful, are not able to dominate the boardroom or to dictate corporate policy. Instead, they aim at persuading other shareholders to support their candidates, and then influencing decision-making inside the boardroom. Such a strategy differentiates hedge fund activists from the corporate raiders of the 1980s who tended to seek outright control, as well as limits the scope for extraction of private benefits.

\subsection{Personal characteristics of new and departing directors}

Some institutional investors, such as BlackRock and State Street, have publicly expressed concerns about the directors who are added to corporate boards as a result of settlements rather than victory in a proxy fight where institutional investors would have a say. We aim to assess these concerns about the quality of the new directors in two ways. First, we examine the personal characteristics of the directors who enter (and leave) the board following settlement agreements. 
Second, we test in the next section whether activist-affiliated and activist-desired directors receive lower voting support at annual general meeting elections.

To examine the personal characteristics of directors who enter and leave the boardroom following settlement agreements, we focus on three director traits that are likely to proxy for their effectiveness as overseers. The first is a dummy variable Age > 70 for directors who are at least in their seventies. The second is Connectedness, which is the number of different listed companies a director served on as a board member over the five preceding years. This measure assumes that directors preserve personal connections they made in the recent past (Stuart and Yim (2010)). For the departure analysis, we also use the variable Tenure, defined as years of service on the current board, which might reflect both experience and entrenchment.

Table 9 shows the results of linear probability regressions on all director-year observations for treatment and control firms covered in the Board Magazine Directors Database. To increase statistical power by decreasing the number of interaction terms to estimate, we aggregate the years around the settlement, around proxy fight announcement, and around the initial activist intervention into three-year periods. $d[P O S T S], d[P O S T D]$, and $d[P O S T C]$ are equal to zero in the three years prior to the settlement year, initial intervention year, or contest announcement year, respectively, and equal to 1 in the three years afterwards. The incremental probability of the addition or departure of directors with certain characteristics post settlement is captured by the three-way interaction terms Settlement $d$ [POSTS] A Age>70, Settlement - d[POSTS] . Connectedness, and Settlement $\cdot d[$ POSTS] $\cdot$ Tenure. Similarly, we define three-way interactions for the initial intervention and the announcement of voted proxy contests.

What is noteworthy about this analysis is how the characteristics of the directors involved in board turnover differ when turnover is associated with the initial activist intervention versus with a settlement. We find that in the $[s, s+2]$ period following a settlement, target firms show an abnormal increase in the appointment of more well-connected directors and an abnormal decrease in the appointment of older directors relative to control firms. We observe a similar but weaker pattern of director appointments around the time of initial intervention and following the announcement of proxy fights that go to a vote. With respect to director departures, the likelihood of incumbent directors with longer tenure to resign increases abnormally following settlement agreements and following proxy fight announcements, but not following the initial intervention. 
Taken together, these results imply that following settlements, boards end up being comprised of fewer old directors, and more shorter-tenured and better-connected directors than prior to the settlement, thereby arguably increasing board effectiveness according to the general consensus from the literature (Core, Holthausen, and Larcker (1999), Larcker, So, and Wang (2013), Nili (2016), Huang and Hilary (2018)).

\section{Stock market reactions}

In examining stock market reactions, the literature has paid close attention to the stock price reactions accompanying the initial campaign launch disclosure (usually the filing of SEC 13(d) schedules) that alert the market to the purchase of a significant stake by an activist. The existing literature to date has provided consistent evidence indicating that hedge fund activism announcements lead to a price increase on the order of about $4.5 \%$ during the 20 -day window which is not reversed in the longer term (for up to five years) for the time period of 1994 to $2016 .^{23}$ Moreover, this positive reaction from the stock market is justified by the ex post improvement in both operating performance and corporate governance, e.g., increases in the return on assets and in CEO pay-for-performance. (e.g., Bebchuk, Brav, and Jiang (2015)).

We first examine the market reaction to the announcement of a settlement agreement. Panel A of Table 10 shows that there is a statistically significant, $1.16 \%$ average buy-and-hold abnormal return in excess of the value-weighted market benchmark during the $[t-2, t+2]$ day window around the settlement date; the results are slightly stronger if the time window is expanded to $[t-3, t+3]$.

When we use the estimates of abnormal returns as a dependent variable in Panel B of Table 10, then high-impact settlements (those that stipulate at least 3 director additions or departures, or a strategic transaction, or CEO turnover) earn an extra 3 percentage points compared to non-high impact settlements. This result is consistent with prior literature documenting higher announcement and holding-period returns for activism campaigns that result in board turnover, takeovers, and other forms of corporate restructurings (Greenwood and Schor (2009); Becht, Franks, Grant, and Wagner (2017)).

23 See the updated analysis provided by Brav, Jiang, and Barry (2019), available at: http://people.duke.edu/ brav/HFactivism_March_2019.pdf. 
Among the components of high-impact settlements, strategic transactions (sale or merger of the firm or of parts of the firm's assets) generate the highest short-term returns, specifically, between $8.1 \%$ and $8.9 \%$ above the average abnormal return of settlements in which no strategic transaction is specified. CEO turnover is associated with an insignificant abnormal price increase of about 2.6\%. These results are consistent with Corum (2018) who predicts that settlements, which specify the ultimate outcomes that activists seek, will generate larger market reactions.

Finally, in untabulated analysis, looking back in time, we compare the abnormal returns around the initial campaign announcement for the sample of campaigns that subsequently lead to a settlement with campaigns that do not. We find that the former have a significantly greater market reaction at campaign announcement than the latter. Specifically, for a 5 (7) day window centered on the campaign announcement date, we find market-adjusted buy-and-hold returns of 3.74\% (4.2\%) for campaigns that were eventually settled and only $2.59 \%(2.89 \%)$ for campaigns that were not settled. This pattern is consistent with markets viewing settlements favorably and being able to identify at the outset that some campaigns are more likely to results in settlement than others.

Overall, the results presented in this Section are consistent with the market reacting favorably to settlements, viewing their direct and indirect effects as overall value-increasing. The results are also inconsistent with shareholders viewing privately-negotiated settlement agreements as devices for activist rent extraction that are overall value-reducing for other shareholders.

\section{The aftermath of settlements}

We have seen that, although hedge fund activists are ultimately interested in leadership and operational changes, settlement agreements often focus on the introduction of new directors. We have argued that activists seek to obtain such new directors in order to facilitate the subsequent occurrence of leadership and operational changes. In this Section, we test the hypothesis which, in line with the incomplete contracting, asymmetric information, and reputational concerns theories, predicts the occurrence of CEO turnover and operational changes in the years following settlement agreements:

Hypothesis H6: Settlement agreements are positively associated with the occurrence of future CEO turnover and operational changes. 
To test this hypothesis, we employ the same empirical methodology that we developed in Section 6.1, which relies on propensity-score matched samples and difference-in-differences estimation. Below we analyze in turn how settlements are associated with subsequent CEO turnover, shareholder payouts, strategic transactions, and operating performance. We conclude by examining whether there is post-settlement evidence of rent extraction by the activist at the expense of other shareholders.

\subsection{CEO turnover}

While the high portion of settlement agreements that contractually specify director additions (84\%) suggest that the above documented board renewal is directly attributable to the settlement agreement, only very few settlements stipulate the ouster of the incumbent CEO (5.3\%). While this result is consistent with Hypothesis H3, it might still seem puzzling given that Becht, Franks, Mayer, and Rossi (2009) find that replacing target firms' CEOs is an important mechanism through which activists can implement their objectives. In line with this claim, untabulated analyses show that CEO turnover spikes to an annual rate of $28 \%$, in the year after settlement, up from a pre-settlement average of about $12 \%$ annually, and significantly higher than the rate of turnover among matched control firms of $11 \%$. CEO turnover reverts back to $14 \%$ by the third year following settlement and lingers at about that rate until the fifth year. Taken together, these results suggest that the CEO is allowed to resign "quietly" after the settlement as opposed to her ouster being publicly announced in the settlement agreement.

Table 11 examines CEO turnover around initial activist interventions, the announcement of proxy fights that go to a vote, and settlement agreements in a regression framework using a similar difference-in-differences specification as in Table 7. In the year of the settlement agreements, the CEO turnover rate at target firms increases by between 6.3 and 7.7 percentage points in excess of the change in CEO turnover at control firms during the same time. This abnormal increase grows even further in the first year following the settlement with an abnormal increase (relative to the year prior to the settlement or placebo year) of between 13.2 and 14 percentage points. Importantly, we do not observe abnormal turnover prior to the settlement and the difference-in-differences estimates revert back to zero by year $s+2$ or $s+3$. Taken together, these results provide strong support for Hypothesis H6 that settlements facilitate leadership changes down the road. 
In the years following the announcement of voted proxy contests, we find increases in the CEO turnover rate that are of similar magnitude compared to CEO turnover following settlements, suggesting again that settlements might be a less confrontational, and hence cheaper, means to achieve similar leadership changes as going all the way to a vote. We also document a significant increase in abnormal CEO turnover in the year of the initial intervention and the two subsequent years. This result is in line with the notion that many activism campaigns are successful in replacing the CEO even in the absence of an explicit settlement or proxy vote, potentially signaling the presence of informal settlements.

To the extent that activists attempt to replace CEOs at target companies as a way to restore governance and performance, this effort should be reflected in an increased sensitivity of CEO turnover to performance. To this end, we test whether activism, settlement agreements, and proxy fights affect the relation between prior firm performance and CEO turnover. Specifically, we run a linear probability model for CEO turnover at the firm-year level that is similar to the model in Table 9. The key independent variables are three-way interaction terms between indicator variables for the time periods around the launching of activism campaigns, settlement agreements, and proxy fight announcements and a measure of prior-year stock return performance (e.g., Settlement . $d[$ POSTS] - Stock Returns for settled campaigns). Table 12 reports the results, which suggest that CEO turnover following settlements is different, namely more performance-based, than CEO turnover following initial activist interventions or following the announcement of voted proxy contests.

The negative and statistically significant main effect on Stock Returns shows that past stock return performance is negatively related to the likelihood of CEO turnover among control firms in the pre-placebo period, which is a standard finding in the governance literature (e.g., Kaplan and Minton (2012)). Most important in our finding is that the negative and significant coefficient on Settlement $\cdot d[$ POSTS] $\cdot$ Stock Returns is around three times as large as the Stock Returns baseline effect, which means that the abnormal (i.e. control firm adjusted) increase in the CEO turnoverperformance sensitivity among target firms from pre to post settlement is economically significant. For the initial intervention or the year following the announcement of proxy fights that go to a vote, we find no significant increase in the relation between CEO turnover and firm performance. Overall, the empirical evidence implies that activists oust CEOs more selectively following settlement agreements. 


\subsection{Shareholder payouts}

Activists often seek an increase in shareholder payouts, and Brav, Jiang, Partnoy and Thomas (2008) document increases in payout among target firms following activist interventions. As we show in Table 5, however, a share buyback is directly stipulated in only $5.3 \%$ of our settlement agreements. When we go beyond the contractual stipulations in the settlement and examine the annual level of payout in the years surrounding the settlement date, we find that payout yield, which is the sum of dividends and share repurchases scaled by the firm's market capitalization, spikes in the year that the settlement agreement is filed. This can be seen in Table 13. In the settlement year, target firm payout yield increases by 1.1 to 1.2 percentage points, in excess of the change in payout among control firms, compared to the year prior to settlement or placebo. These magnitudes are economically significant given the average payout yield of around $4 \%$ observed in the 11 years surrounding the settlement agreement. However, we find some evidence that payout yield was lower among firms that ultimately settle compared to matched control firms in the pre-settlement years. This suggests that activists do not demand unreasonable payout from target firms but rather revert target firm payout back to normal levels.

Similar to the CEO turnover-performance analyses, settlements are different from the initial intervention or proxy fights also with respect to payout. We find no evidence of abnormal changes in payout following activism campaign launch or the announcement of proxy contests that go to a vote. Overall these results support Hypothesis H6 that settlement agreements facilitate the distribution of free cash flow to shareholders in the future.

\subsection{Strategic transactions}

Prior research documents activists' ability to put target firms into play (Greenwood and Schor (2009), Burkart and Lee (2015), Boyson, Gantchev, and Shivdasani (2017), Corum and Levit (2018)). However, only about $8 \%$ of settlement agreements signal the possibility for a strategic transaction. ${ }^{24}$ As discussed in the development of Hypothesis H3, strategic transactions such as selling the target firm are difficult to contract on in the settlement due to incomplete contracting, asymmetric information, and potential reputation concerns but, as Hypothesis H6

$242.5 \%$ of agreements specify the sale of the firm or a merger, another $0.5 \%$ the sale of parts of the firm's assets, and $5.8 \%$ stipulate the formation of a Strategic Transaction Committee on the board of directors. 
predicts, settlements can be used to facilitate a transaction later on. Thus, in this section we examine whether the likelihood of target firms being sold increases in the aftermath of settlements.

In Table 14, we include only those years following the initial intervention or placebo year and find an increase in the probability of target firm stock market delisting following settlements. Importantly, this increase in overall delisting propensity is driven by those delistings that are related to mergers and acquisitions (M\&A) or going-private transactions, while we find no increase in distress-related delistings post settlement. Estimates of the abnormal probability of M\&A or going-private transactions is about 6.7 percentage points higher than controls in the year of the settlement. After controlling for the dynamics of delistings around the initial intervention, the abnormal likelihood of an acquisition or going private transaction among settlement targets decreases to 2.6 percentage points in the year of settlement relative to control firms. While this is an economically large magnitude given an average in-sample likelihood of M\&A or going-private transactions of $5.4 \%$ the estimate is statistically insignificant at conventional levels.

For the years following initial activist interventions, we find that the likelihood of stock market delistings is abnormally high, which is almost entirely driven by M\&A and going private transactions. The rate of distress-related delistings is marginally higher among target firms compared to control firms only in the third year following the campaign launch year. For proxy contests, we find some evidence that delistings occur less frequently in the year of and the year following the announcement year, which could be a partly mechanical relation however if those are the years during which contests are actually voted on. In other words, we cannot observe a contested vote if the company has delisted prior to the shareholder meeting. In the third year following proxy fight announcement, we find that the probability of delisting increases, which is driven by M\&A and going private transactions. While the results for settlement agreements alone are weak, collectively, these findings imply that target firms are more likely to delist for favorable reasons (M\&A and going private) than control firms, refuting the claim that hedge fund activists destabilize target firms. ${ }^{25}$

${ }^{25}$ For an example of such claims, see Reuters, 11/16/2015, "The Cannibalized Company." 


\subsection{Operating performance}

Several prior studies on hedge fund activism document deterioration in ROA and Tobin's Q among target firms prior to the intervention, and a full recovery afterwards [for recent evidence, see Bebchuk, Brav, and Jiang (2015) and Gantchev, Gredil, and Jotikasthira (2018)]. In this section, we examine whether post-intervention performance increases are similar among activism campaigns that lead to a settlement or to a proxy vote. The first three columns of Table 15 examine ROA. In columns 2 and 3, we find target firm performance indeed deteriorates from year $t$-3 through the year of the initial intervention. From year $t+1$ through $t+5$, ROA improves but this improvement turns significant only by $t+5$. In columns 1 to 3 , we find little evidence that settlements are followed by improvements in profitability relative to controls. Only in the first year following the settlement do we observe an abnormal improvement in ROA, but this is not sustained in later years. For voted proxy contests, however, we observe significant incremental improvements in profitability in four out of five years following the contest announcement.

Columns 4 to 6 present the results for Tobin's Q. We find significant abnormal (i.e., in excess of control firms) improvements in Tobin's Q relative to the year before settlement. These improvements start materializing in the year of the settlement, which is consistent with the market reaction to settlement disclosure presented in Table 10. For campaigns that lead to a proxy vote, the coefficients on Voted Contest $\cdot d[c+1]$ through Voted Contest $\cdot d[c+5]$ also show an increasing pattern, but these coefficients are not statistically significant, potentially due to the small number of voted proxy contests. Four out of the five coefficients on the interaction terms identifying the years following the initial intervention are positive but none of them attain statistical significance at conventional levels.

These results suggest that more confrontational campaigns, such as those that lead to a settlement or a proxy vote, are associated with stronger improvements in firm valuations, which is inconsistent with the claim that performance improvements associated with activism are entirely due to stock picking. These findings also provide some support for Hypothesis H6 and the claim that settlements facilitate operational changes down the road and that these changes are value enhancing. 


\subsection{Rent-extraction?}

Commentators and some institutional shareholders have expressed the concern that settlements, which activist hedge funds and incumbents make without other shareholders being present at the bargaining table, enable hedge fund activists to push for a short-term agenda to extract rents from other shareholders with a longer investment horizons. We find, however, that the average length of engagement is 979 days for campaigns that are settled and 660 days for campaigns that are not settled, which is a statistically significant difference. This long period for settled campaigns is natural to expect since a settlement takes time to obtain and takes additional time to bear fruit. This pattern is inconsistent with a concern that settlements push companies in directions favored by agents with very short time horizons.

In this concluding subsection we further examine this concern. In particular, we investigate whether settlements enable activists to pressure incumbents to a) accept the appointment of new directors who are not favored by other shareholders and/or b) buy out the activist privatelynegotiated transactions that might resemble the "greenmail" practices of the 1980s. Thus, we find no evidence to support the rent-extraction concern.

\subsubsection{Self-serving director appointments}

First, we test whether directors added to the board during settlement negotiations, that is, without the vote of other shareholders, are perceived by investors as less qualified or committed. Specifically, we examine director voting outcomes at target firms' annual general meetings for those new directors whose names we can match to director names in the ISS Voting Analytics data. Table 16 reports the results of analyses where the dependent variables are the fraction of votes supporting (column 1) or against (column 2) a particular director in a given year, or the fraction of votes withheld (column 3). The directors whose voting results are considered are classified into four mutually-exclusive categories based on whether they were added following a settlement and, among directors added afterwards, whether they are affiliated with, desired by, or unrelated to ("Other") the activist. These classifications are captured by three indicator variables with the fourth group, the omitted base case, being incumbent directors who were already on the target firm's board prior to campaign launch. 
Columns 1 and 2 of Table 16 show that directors who are added to the board following a settlement (irrespective of whether affiliated with or desired by the activist) generally receive significantly more votes in their favor and fewer withheld votes compared to incumbent directors. Specifically, new activist-affiliated directors receive 1.7 percentage points more in their favor (1.8 percentage points less against them) than incumbent directors. For activist-desired directors, these differences increase to 3.8 percentage points for supporting votes and 3.9 percentage points for disapproving votes, respectively, which is similar to the third category of other new directors. At the bottom of the table, partial F-tests show that activist-desired directors receive more voting support (and less dissent) than activist-affiliated directors but there is no significant difference between activist-affiliated directors and other directors. Taken together, our results provide no evidence that directors who join boards following settlements receive lower voting support than incumbent directors and we find no evidence that activist-affiliated or activist-desired directors are less popular than other new directors.

\subsection{2 "Greenmail"}

Some commentators have expressed concern that target companies might buy out the activist in some settlements, and that settlements might thus enable activists to extract rents at the expense of other shareholders similar to economic rents corporate raiders might have extracted during the 1980s through "greenmail." ${ }^{26}$ We investigate whether such a concern is empirically justified.

To this end, we search for information about privately negotiated buybacks in the settlement agreements and other company disclosures, Capital IQ, SDC Platinum, and FactSet Shark Watch. We find that only 19 settlements out of 399 during our period were followed by a privately-negotiated buyback that enabled the activist to sell shares to the issuer. Furthermore, in a large majority of these cases, the record indicates that the buyback was executed without a premium to the market price, and in the remaining cases we were unable to determine the price of the transaction. Thus, we find no evidence supporting the greenmail concern.

\footnotetext{
${ }^{26}$ See , e.g., Wall Street Journal, 6/11/2014, “Activist Funds Dust Off 'Greenmail' Playbook” and Forbes, 2/19/2016, "Greenmail Lives! Activist RiverNorth Folds At Fifth Street After A Tannebaum-Led Buyout."
} 


\section{Conclusion}

Settlement agreements between the activist and the target's board have been playing an increasingly important role in the corporate governance landscape. Using a comprehensive handcollected data set, we provide the first systematic analysis of the drivers, nature, and consequences of such settlement agreements.

We identify the factors that determine the likelihood of a settlement, showing that the evidence is consistent with settlements being more likely when the activist has a credible threat to win board seats in a proxy fight and when incumbent directors face significant reputation concerns. We then document that settlements bring about major changes in board composition rather than provide directly the operational changes that activists seek, but that settlements are followed by such changes, including increases in CEO turnover, increased payout to shareholders, and improvements in valuation. We find no evidence that settlements allow activists to appoint directors who are not supported by other shareholders or that they enable the extraction of economically meaningful rents through greenmail. Indeed, the disclosure of settlements is accompanied by positive stock price reactions. Our analysis highlights the importance of settlements. It also provides an empirical foundation on which future examination of settlements and activist engagements more generally can build. 


\section{Appendix A}

Variable definitions.

\section{Settlement characteristics}

High Board Turnover is an indicator variable equal to 1 if the settlement agreement stipulates that at least 3 new directors join the board or at least 3 incumbent directors leave the board and equal to 0 otherwise.

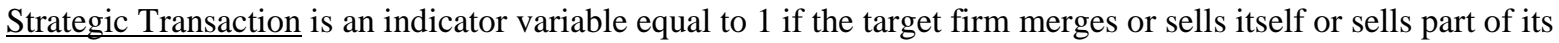
assets and equal to 0 otherwise.

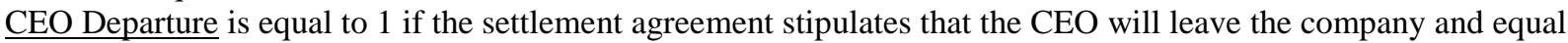
to 0 otherwise.

High Impact Settlement is an indicator variable equal to 1 if 'High Board Turnover' is equal to 1 or 'CEO

Departure' is equal to 1 or 'Strategic Transaction' is equal to 1 and equal to 0 otherwise.

Buy \& Hold Industry-Adjusted Return is the continuously-compounded industry-adjusted share price performance around the date the settlement agreement is reached.

Identifiers for time relative to initial activist intervention, proxy fight announcement or settlement

$13 \mathrm{D}$ is equal to 1 for hedge fund activism target firms and equal to 0 otherwise.

Settlement is equal to 1 for target firms that settle with the activist and equal to 0 otherwise.

Voted Contest is equal to 1 for target firms that experience a contested proxy vote and equal to 0 otherwise.

$\mathrm{d}[\mathrm{t}+\mathrm{k}]$ with $-5 \leq \mathrm{k} \leq 5$ is a set of indicator variables equal to 1 in year $\mathrm{k}$ relative to the initial intervention year or placebo year and equal to 0 otherwise.

$\underline{\mathrm{d}[\mathrm{s}+\mathrm{k}]}$ with $-5 \leq \mathrm{k} \leq 5$ is a set of indicator variables equal to 1 in year k relative to the settlement year or placebo year and equal to 0 otherwise.

$\underline{\mathrm{d}[\mathrm{c}+\mathrm{k}]}$ with $-5 \leq \mathrm{k} \leq 5$ is a set of indicator variables equal to 1 in year k relative to the proxy fight announcement year (for voted proxy contests) or placebo year and equal to 0 otherwise.

d[POSTD] is equal to 0 in years $\mathrm{t}-1$ through $\mathrm{t}-3$ around the initial activist intervention or placebo year and equal to 1 in years $t$ through $\mathrm{t}+2$.

d[POSTS] is equal to 0 in years s- 1 through s-3 around the settlement year or placebo year and equal to 1 in years $\mathrm{s}$ through $\mathrm{s}+2$.

$\mathrm{d}[\mathrm{POSTC}]$ is equal to 0 in years c-1 through c-3 around the proxy fight announcement year (for voted proxy contests) or placebo year and equal to 1 in years $\mathrm{c}$ through $\mathrm{c}+2$.

\section{CEO, board and director characteristics}

CEO Age $>62$ is equal to 1 if the CEO is older than 62 and equal to 0 otherwise.

\# Director Additions is the number of new directors on the board.

\# Director Departures is the number of directors that leave the board.

Favored and Affiliated Director is equal to 1 if a new director is affiliated with the activist and equal to 0 otherwise.

Favored but Unaffiliated Director is equal to 1 if a new director is favored by but unaffiliated with the activist and equal to 0 otherwise.

Other New Director is equal to 1 if a new director is neither desired by nor affiliated with the activist.

Favored and Affiliated Director Added Following Settlement is equal to 1 for activist-affiliated directors who were added to the board following a settlement and equal to 0 otherwise.

Favored but Unaffiliated Director Added Following Settlement is equal to 1 for activist-desired but unaffiliated directors who were added to the board following a settlement and equal to 0 otherwise.

Other New Director Added Following Settlement is equal to 1 for directors who were added to the board following a settlement but are neither activist-affiliated nor activist-desired and equal to 0 otherwise.

Age $>70$ is an indicator variable equal to 1 if the director is older than 70 and equal to 0 otherwise.

\# Directors Older than 70 is the number of directors who are older than 70.

\# Outside Directors Older than 70 is the number of outside directors who are older than 70 .

Connectedness is the number of other boards the director served on over the past 5 years.

Tenure is the number of years the director has been on the board of the company

Directors' Average \# Directorships is the average number of directorships held by incumbent board members.

Outside Directors' Avg \# Directorships is the average number of directorships held by incumbent outside directors. Board Chair Up for Election is equal to 1 if the board chair is up for election at the next shareholder meeting. CEO Up for Election is equal to 1 if the CEO is up for election at the next shareholder meeting.

Fraction of Votes Supporting Director is the proportion of votes at the annual meeting supporting the director. Fraction of Votes Against Director is the proportion of votes at the annual general meeting against the director. Fraction of Votes Withheld is the proportion of votes at the annual general meeting withheld in a director election 


\section{Appendix A (continued)}

\section{Activism campaign characteristics}

\# Campaigns is the number of campaigns launched by the activist in the past 5 years.

\# Settlements is the number of settlements reached by the activist in the past 5 years.

\# Successful Campaigns is the number of campaigns launched by the activist in the past 5 years during which the activist achieved its campaign goals.

Market Reaction Past Campaigns is the average buy-and-hold market-adjusted return over a 7-day window centered on the campaign announcement date for all campaigns launched by the activist in the past 5 years. \# Proxy Fights is the number of proxy fights launched by the activist in the past 5 years.

Proxy Fight is an indicator variable equal to 1 if the activist has threatened a proxy fight and equal to 0 otherwise. High Activist Ownership is an indicator variable equal to 1 for campaigns with activist ownership above the sample median and equal to 0 otherwise.

\section{Company characteristics and outcomes}

Market Cap is the target firm's market capitalization in millions.

Multiple Share Classes is equal to 1 if the target firm's share structure includes multiple classes.

Analyst Coverage is the number of sell-side analysts covering the firm.

ROA is earnings before interest, taxes, and depreciation over lagged total assets.

Tobin's $Q$ is the sum of the book value of debt and the market value of equity scaled by the sum of the book value of debt and the book value of equity.

Book / Market is the book value of equity scaled by the market value of equity.

Insider Ownership is the percentage of shares held by incumbent executives and directors.

Cash Flow Volatility is the standard deviation of operating cash flows over the past five years.

Abnormal Returns Pre-13D is the market-adjusted share price performance over the 12 months leading up to the 13(d) filing.

Stock Returns is equal to the continuously-compounded stock return over the calendar year.

Delisting is an indicator variable equal to 1 the year of a stock market delisting and equal to 0 otherwise.

Acquisition / Going Private Delisting is an indicator variable equal to 1 in the year of a stock market delisting that is related to merger and acquisition or going private transactions and equal to 0 otherwise.

Distress Delisting is an indicator variable equal to 1 in the year of a stock market delisting that is related to

financial distress based on the CRSP delisting codes and equal to 0 otherwise.

Payout Yield is the sum of dividends and repurchases divided by market capitalization

CEO Turnover is an indicator variable equal to 1 if the CEO leaves the firms and equal to 0 otherwise. 


\section{References}

Aghion, P., Bolton, P., 1992. An incomplete contracts approach to financial contracting. The Review of Financial Studies 59(3), pp. 473-494.

Appel, I. R., Gormley, T. A., Keim, D. B., 2018. Standing on the shoulders of giants: The effect of passive investors on activism. Working paper.

Aslan, H. Kumar, P., 2016. The product market effects of hedge fund activism. Journal of Financial Economics 119(1), pp. 226-248.

Back, K., Collin-Dufresne, P., Fos, V., Li, T., Ljungqvist, A., 2018. Activism, strategic trading, and liquidity. Econometrica, 86(4), pp. 1431-1463.

Bebchuk, L. A., 1984. Litigation and settlement under imperfect information. The RAND Journal of Economics, pp. 404-415.

Bebchuk, L., Brav, A., Jiang, W., 2015. The long-term effects of hedge fund activism. Columbia Law Review 115(5).

Bebchuk, L. A., Brav, A., Jackson, R. J., Jiang, W., 2013. Pre-disclosure accumulations by activist investors: Evidence and policy. Journal of Corporation Law, 39(1), pp. 1-34.

Bebchuk, L., Klement, A., 2012. Negative-expected-value suits. In: Sanchirico, C. (Ed), Procedural Law and Economics.

Becht, M., Franks, J., Mayer, C. Rossi, S., 2009. Returns to shareholder activism: Evidence from a clinical study of the Hermes UK Focus Fund. Review of Financial Studies 22(8), pp. 3093-3129.

Becht, M., Franks, J. R., Grant, J., Wagner, H. F., 2017. The returns to hedge fund activism: An international study. Review of Financial Studies 30(9), pp. 2933-2971.

Bourveau, T., Schoenfeld, J., 2017. Shareholder activism and voluntary disclosure. Review of Accounting Studies, 22(3), pp. 1307-1339.

Boyson, N. M., Gantchev, N., Shivdasani, A., 2017. Activism mergers. Journal of Financial Economics, 126(1), pp. 54-73.

Boyson, N. M., Ma, L., Mooradian, R. M., 2016. Serial activists. Working paper.

Boyson, N. M., Mooradian, R. M., 2011. Corporate governance and hedge fund activism. Review of Derivatives Research 14(2), pp. 169-204.

Boyson, N. M., Pichler, P., 2019. Hostile resistance to hedge fund activism. Review of Financial Studies 32(2), pp. 771-817

Brav, A., Jiang, W., Kim, H., 2015a. The real effects of hedge fund activism. Review of Financial Studies 28(10), pp. 2723-2769.

Brav, A., Jiang, W., Kim, H., 2015b. Recent advances in research on hedge fund activism: Value creation and identification. Annual Review of Financial Economics 7, pp. 579-595.

Brav, A., Jiang, W., Ma, S., Tian, X., 2018. How does hedge fund activism reshape corporate innovation?. Journal of Financial Economics, 130(2), pp. 237-264

Brav, A., Jiang, W., Partnoy, F., Thomas, R., 2008. Hedge fund activism, corporate governance, and firm performance. The Journal of Finance 63(4), pp. 1729-1775.

Burkart, M., Lee, S., 2015. Hedge fund activism vs. hostile takeover bids. Working paper.

Cheng, C. A., Huang, H. H., Li, Y., Stanfield, J., 2012. The effect of hedge fund activism on corporate tax avoidance. The Accounting Review 87(5), pp. 1493-1526.

Cheng, C.S., Huang, H. H., Li, Y., 2015. Hedge fund intervention and accounting conservatism. Contemporary Accounting Research 32(1), pp. 392-421.

Clifford, C. P., 2008. Value creation or destruction? Hedge funds as shareholder activists. Journal of Corporate Finance 14(4), pp. 323-336.

Coffee, John, Jackson, R. J., Mitts, J. R., R. E. Bishop, 2019. Activist directors and agency costs: What happens when an activist director goes on the board?. Cornell Law Review 104, 381-466.

Collin-Dufresne, P., Fos, V., 2015. Do prices reveal the presence of informed trading?. The Journal of Finance 70(4), pp. 1555-1582. 
Core, J. E., Holthausen, R. W., Larcker, D. F., 1999. Corporate governance, chief executive officer compensation, and firm performance. Journal of Financial Economics 51(3), pp. 371-406.

Corum, A.A., 2018. Activist Settlements. Working Paper.

Corum, A. A., Levit, D., 2019. Corporate control activism. Journal of Financial Economics.

Daugherty. A. J. Reinganum, 2017. Settlement and trial: Selected analyses of the bargaining environment. In: Parisi, F., Oxford Handbook of Law and Economics.

Edmans, A., Fang, V. W., Zur, E., 2013. The effect of liquidity on governance. The Review of Financial Studies 26(6), pp. 1443-1482.

Falato, A., Kadyrzhanova, D., Lel, U., 2014. Distracted directors: Does board busyness hurt shareholder value?. Journal of Financial Economics, 113(3), pp. 404-426.

Fich, E. M., Shivdasani, A., 2006. Are busy boards effective monitors?. The Journal of Finance, 61(2), pp. 689-724.

Fos, V., 2017. The disciplinary effects of proxy contests. Management Science 63(3), pp. 655-671.

Fos, V., Jiang, W., 2016. Out-of-the-money CEOs: Private control premium and option exercises. Review of Financial Studies 29(6), pp. 1549-1585.

Fos, V., Tsoutsoura, M., 2014. Shareholder democracy in play: Career consequences of proxy contests. Journal of Financial Economics 114(2), pp. 316-340.

Gantchev, N., 2013. The costs of shareholder activism: Evidence from a sequential decision model. Journal of Financial Economics 107(3), pp. 610-631.

Gantchev, N., Gredil, O., Jotikasthira, C., 2018. Governance under the gun: Spillover effects of hedge fund activism. Forthcoming Review of Finance.

Gantchev, N., Jotikasthira, C., 2017. Institutional trading and hedge fund activism. Management Science, 64(6), pp. 2930-2950.

Gantchev, N., Merih Sevilir, Anil Shivdasani, 2019, Activism and empire building, working paper.

Gow, I. D., Shin, S. P., Srinivasan, S., 2014. Activist directors: Determinants and consequences. Working paper.

Gow, I. D., Shin, S. P., Srinivasan, S., 2016. Consequences to directors of shareholder activism. Working paper.

Greenwood, R., Schor, M., 2009. Investor activism and takeovers. Journal of Financial Economics 92(3), pp. 362-375.

Guo, J., Utham, V., Wang, G.J., 2019. Shepherds in wolves' clothing? Hedge fund activism using corporate divestitures. Working paper.

Hart, O. (2017). Incomplete contracts and control. American Economic Review, 107(7), pp. 1731-52.

He, Y. E., Li, T., 2018. The benefits of friendship in hedge fund activism. Working paper.

Hege, U., Zhang, Y., 2019. Activism pressure and the market for corporate assets. Working paper.

Huang, S., Hilary, G., 2018. Zombie board: Board tenure and firm performance. Journal of Accounting Research, 56(4), pp. 1285-1329.

Jenter, D., Lewellen, K., 2015. CEO preferences and acquisitions. The Journal of Finance, 70(6), pp. 28132852.

Johnson, T., Swem, N., 2017. Reputation and investor activism. Working paper.

Jiang, W., Wan, H., Hao, S., 2016. Reputation concerns of independent directors: Evidence from individual director voting. Review of Financial Studies 29(3), pp. 655-696.

Jiang, W., Li, T., Mei, D., 2018. Influencing control: Jawboning in risk arbitrage. The Journal of Finance, 73(6), pp. 2635-2675.

Kaplan, S. N., Minton, B. A., 2012. How has CEO turnover changed?. International Review of Finance, 12(1), pp. 57-87.

Kim, Sehoon, 2018. Hedge fund activism and internal capital markets. Working paper.

Klein, A., Zur, E., 2009. Entrepreneurial shareholder activism: Hedge funds and other private investors. The Journal of Finance 64(1), pp. 187-229.

Klein, A., Zur, E., 2011. The impact of hedge fund activism on the target firm's existing bondholders. Review of Financial Studies 24(5), pp. 1735-1771. 
Krishnan, C. N. V., Partnoy, F., Thomas, R., 2016. The second wave of hedge fund activism: The importance of reputation, clout, and expertise. Journal of Corporate Finance 40, pp. 296-314.

Larcker, D. F., So, E. C., Wang, C. C. Y., 2013. Boardroom centrality and firm performance. Journal of Accounting and Economics 55(2), pp. 225-250.

Levit, D., 2018. Soft shareholder activism. Forthcoming Review of Financial Studies.

McCahery, J. A., Sautner, Z., Starks, L. T., 2016. Behind the scenes: The corporate governance preferences of institutional investors. The Journal of Finance 71(6), pp. 2905-2932.

Mietzner, M., Schweizer, D., 2014. Hedge funds versus private equity funds as shareholder activists in Germany-differences in value creation. Journal of Economics and Finance 38(2), pp. 181-208.

Minton, B. A., Schrand, C., 1999. The impact of cash flow volatility on discretionary investment and the costs of debt and equity financing. Journal of Financial Economics, 54(3), pp. 423-460.

Nili, Y., 2016. The "New Insiders": Rethinking independent directors' tenure. Hastings Law Journal 67(6).

Norli, Ø., Ostergaard, C., Schindele, I., 2015. Liquidity and shareholder activism. Review of Financial Studies 28(2), pp. 486-520.

Prescott, J.J., Katharyn E. Spier, 2016. A comprehensive theory of civil settlement, 91 New York University Law Review, 59.

Schoenfeld, J., 2018. Action-based contracts between firms and shareholders. Working paper.

Shavell, S., 1982. Suit, settlement, and trial: A theoretical analysis under alternative methods for the allocation of legal costs. Journal of Legal Studies 11, pp. 55-82.

Spier, K., 2007. Litigation. In: Polinsky, M., Shavell, S., The Handbook of Law and Economics, North Holland.

Stuart, T. E., Yim, S., 2010. Board interlocks and the propensity to be targeted in private equity transactions. Journal of Financial Economics 97(1), pp. 174-189.

Sunder, J., Sunder, S. V., Wongsunwai, W., 2014. Debtholder responses to shareholder activism: Evidence from hedge fund interventions. Review of Financial Studies 27(11), pp. 3318-3342.

Swanson, E., Young, G., 2017. Are activist investors good or bad for business? Evidence from capital market prices, informed traders, and firm fundamentals. Working paper.

Vega, C., 2006. Stock price reaction to public and private information. Journal of Financial Economics, 82(1), 103-133.

Wickelgren, A. L., 2013. Law and economics of settlement. In: Arlen, J. (Ed.), Research Handbook on the Economics of Tort Law.

Zhang, X. F., 2006. Information uncertainty and stock returns. The Journal of Finance, 61(1), pp. 105-137. 


\section{Figure 1}

Director additions and departures around settlement agreements.

This figure plots the average number of new directors joining the board (top) and incumbent directors leaving the board (bottom) around the year of a settlement agreement and around a placebo year for matched control firms. The sample of settlements consists of all settlement agreements reached between hedge fund activists and target companies during campaigns that were launched between 2000 and 2013. We select untargeted control firms by propensity-scorematching on the year that the settlement agreement is reached. See Section 6.1. Year 0 on the x-axis represents the year during which the settlement agreement was reached.
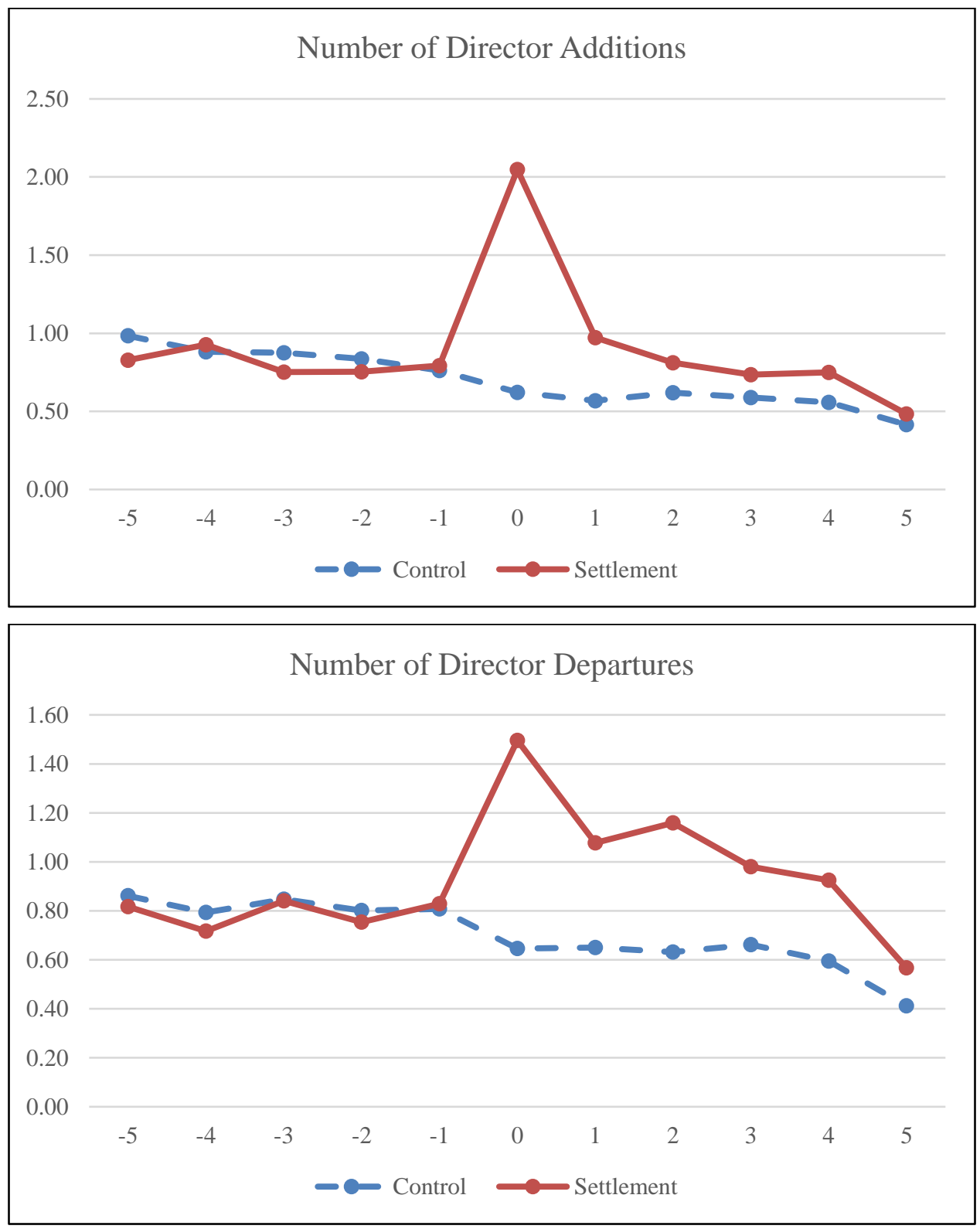


\section{Table 1}

Incidence of settlements and proxy votes over time.

This table documents the distribution of all activism campaigns that were launched between calendar years 2000 and 2013 and the percentage of those interventions that led to settlement agreements between the activist and the target company, the percentage of campaigns that went to a proxy vote, the percentage of campaigns that were settled or went to a proxy vote or both (over the life of a campaign, both outcomes can occur sequentially), and the percentage of settled campaigns relative to all campaigns that were either settled or went to a proxy vote or both.

\begin{tabular}{|c|c|c|c|c|c|}
\hline \multirow{2}{*}{ Year } & \multirow{2}{*}{ Activism Campaigns } & Settlements & Voted Contests & Settlements + Voted Contests & Settlements \\
\hline & & Activism Campaigns & Activism Campaigns & Activism Campaigns & Settlements + Voted Contests \\
\hline 2000 & 116 & $3 \%$ & $3 \%$ & $5 \%$ & $50 \%$ \\
\hline 2001 & 93 & $3 \%$ & $4 \%$ & $8 \%$ & $43 \%$ \\
\hline 2002 & 138 & $7 \%$ & $8 \%$ & $14 \%$ & $50 \%$ \\
\hline 2003 & 128 & $9 \%$ & $4 \%$ & $13 \%$ & $71 \%$ \\
\hline 2004 & 158 & $8 \%$ & $7 \%$ & $13 \%$ & $57 \%$ \\
\hline 2005 & 254 & $11 \%$ & $4 \%$ & $15 \%$ & $73 \%$ \\
\hline 2006 & 344 & $12 \%$ & $3 \%$ & $14 \%$ & $82 \%$ \\
\hline 2007 & 410 & $11 \%$ & $4 \%$ & $15 \%$ & $74 \%$ \\
\hline 2008 & 332 & $15 \%$ & $8 \%$ & $22 \%$ & $71 \%$ \\
\hline 2009 & 166 & $16 \%$ & $3 \%$ & $19 \%$ & $87 \%$ \\
\hline 2010 & 201 & $19 \%$ & $3 \%$ & $22 \%$ & $84 \%$ \\
\hline 2011 & 213 & $17 \%$ & $5 \%$ & $21 \%$ & $82 \%$ \\
\hline 2012 & 217 & $20 \%$ & $2 \%$ & $21 \%$ & $93 \%$ \\
\hline 2013 & 242 & $21 \%$ & $6 \%$ & $27 \%$ & $78 \%$ \\
\hline $\begin{array}{c}\text { Total } \\
\text { (Average) }\end{array}$ & 3012 & $13 \%$ & $5 \%$ & $17 \%$ & $76 \%$ \\
\hline
\end{tabular}

(Average) 
Table 1 (continued)

\begin{tabular}{|c|c|c|c|c|c|}
\hline \multirow{2}{*}{ Year } & \multirow{2}{*}{ Proxy Contests } & Proxy Contests & Voted Contests & Settled Contests & \\
\hline & & Activism Campaigns & Proxy Contests & Proxy Contests & Proxy Contests \\
\hline 2000 & 8 & $7 \%$ & $38 \%$ & $38 \%$ & $25 \%$ \\
\hline 2001 & 8 & $9 \%$ & $50 \%$ & $13 \%$ & $38 \%$ \\
\hline 2002 & 22 & $16 \%$ & $50 \%$ & $32 \%$ & $18 \%$ \\
\hline 2003 & 18 & $14 \%$ & $28 \%$ & $56 \%$ & $17 \%$ \\
\hline 2004 & 24 & $15 \%$ & $46 \%$ & $38 \%$ & $17 \%$ \\
\hline 2005 & 33 & $13 \%$ & $33 \%$ & $42 \%$ & $24 \%$ \\
\hline 2006 & 39 & $11 \%$ & $26 \%$ & $69 \%$ & $5 \%$ \\
\hline 2007 & 46 & $11 \%$ & $35 \%$ & $52 \%$ & $13 \%$ \\
\hline 2008 & 49 & $15 \%$ & $51 \%$ & $33 \%$ & $16 \%$ \\
\hline 2009 & 15 & $9 \%$ & $33 \%$ & $40 \%$ & $27 \%$ \\
\hline 2010 & 20 & $10 \%$ & $35 \%$ & $40 \%$ & $25 \%$ \\
\hline 2011 & 24 & $11 \%$ & $42 \%$ & $38 \%$ & $21 \%$ \\
\hline 2012 & 21 & $10 \%$ & $19 \%$ & $62 \%$ & $19 \%$ \\
\hline 2013 & 34 & $14 \%$ & $44 \%$ & $41 \%$ & $15 \%$ \\
\hline $\begin{array}{c}\text { Total } \\
\text { (Average) }\end{array}$ & 361 & $12 \%$ & $38 \%$ & $45 \%$ & $17 \%$ \\
\hline
\end{tabular}


Table 2

Descriptive statistics on activist interventions.

This table reports descriptive statistics on activist characteristics and target characteristics separately for activism campaigns that lead to a settlement agreement, a proxy vote, or none of the above. The sample covers campaigns launched between 2000 and 2013. The number of observations on the different variables differs depending on the availability of information on that variable. All variables are defined in Appendix A.

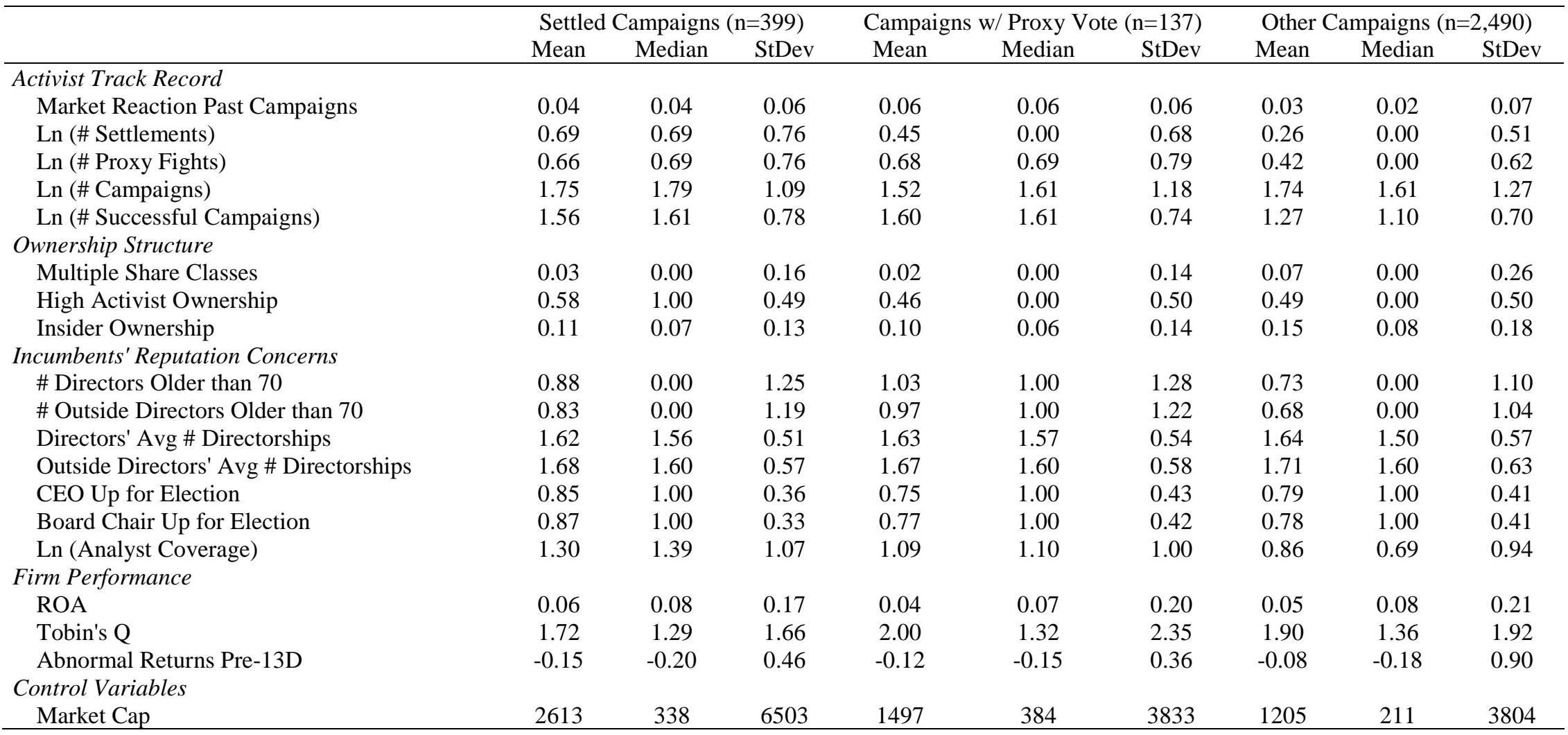




\section{Table 3}

The determinants of settlements and proxy vote vs other campaign outcomes.

The analyses in this table predict whether a campaign leads to a settlement (columns 1, 3, 5, 7), or a proxy vote (columns 2, 4, 6, 8). For campaigns that neither lead to a settlement nor to a proxy vote, these dependent variables are equal to 0 . The sample includes hedge fund activism campaigns launched between 2000 and 2013. The sample size differs across models depending on the availability of the independent variables. The models are estimated using multinomial logit regressions. The coefficient estimates represent relative risk ratios. Standard errors are robust to heteroskedasticity; z-statistics appear in parentheses. $*^{* *}, * *$, and $*$ denote statistical significance at the $1 \%, 5 \%$, and 10\% level, respectively (two-tailed). All variables are defined in Appendix A.

\begin{tabular}{|c|c|c|c|c|c|c|}
\hline \multicolumn{7}{|c|}{ Panel A. Activist track record, and ownership structure } \\
\hline Predicted Outcome & Settlement & Proxy Vote & Settlement & Proxy Vote & Settlement & Proxy Vote \\
\hline \multirow[t]{2}{*}{ Base Outcome } & \multicolumn{6}{|c|}{ Campaigns that Neither Lead to a Settlement Nor to a Proxy Vote } \\
\hline & (1) & (2) & (3) & (4) & (5) & (6) \\
\hline \multicolumn{7}{|l|}{ Activist Track Record } \\
\hline Market Reaction Past Campaigns & $\begin{array}{l}1.052^{*} \\
(1.94)\end{array}$ & $\begin{array}{c}1.167 * * * \\
(2.93)\end{array}$ & & & & \\
\hline Ln (\# Campaigns) & $\begin{array}{c}0.354 * * * \\
(-8.56)\end{array}$ & $\begin{array}{c}0.353 * * * \\
(-4.15)\end{array}$ & & & & \\
\hline Ln (\# Successful Campaigns) & $\begin{array}{c}4.309 * * * \\
(8.58)\end{array}$ & $\begin{array}{c}4.070 * * * \\
(4.66)\end{array}$ & & & & \\
\hline Ln (\# Settlements) & & & $\begin{array}{c}2.624 * * * \\
(9.41)\end{array}$ & $\begin{array}{l}1.214 \\
(1.10)\end{array}$ & & \\
\hline Ln (\# Proxy Fights) & & & $\begin{array}{c}0.990 \\
(-0.10)\end{array}$ & $\begin{array}{c}1.437 * * \\
(2.44)\end{array}$ & & \\
\hline \multicolumn{7}{|l|}{ Ownership Structure } \\
\hline Multiple Share Classes & & & & & $\begin{array}{c}0.455^{* *} \\
(-2.21)\end{array}$ & $\begin{array}{c}0.471 \\
(-1.09)\end{array}$ \\
\hline High Activist Ownership & & & & & $\begin{array}{c}1.850 * * * \\
(4.58)\end{array}$ & $\begin{array}{l}1.144 \\
(0.57)\end{array}$ \\
\hline Insider Ownership & & & & & $\begin{array}{c}0.272 * * * \\
(-2.71)\end{array}$ & $\begin{array}{c}0.060^{* *} \\
(-1.99)\end{array}$ \\
\hline \multicolumn{7}{|l|}{ Firm Performance } \\
\hline ROA & $\begin{array}{c}0.591 \\
(-1.32)\end{array}$ & $\begin{array}{c}0.350 \\
(-1.63)\end{array}$ & $\begin{array}{c}0.692 \\
(-1.09)\end{array}$ & $\begin{array}{c}0.554 \\
(-1.12)\end{array}$ & $\begin{array}{l}1.223 \\
(0.54)\end{array}$ & $\begin{array}{l}0.355^{*} \\
(-1.74)\end{array}$ \\
\hline Tobin's Q & $\begin{array}{c}0.879 * * \\
(-2.26)\end{array}$ & $\begin{array}{l}1.048 \\
(0.68)\end{array}$ & $\begin{array}{c}0.942 \\
(-1.20)\end{array}$ & $\begin{array}{l}1.034 \\
(0.66)\end{array}$ & $\begin{array}{l}0.893^{*} \\
(-1.78)\end{array}$ & $\begin{array}{l}1.035 \\
(0.56)\end{array}$ \\
\hline Abnormal Returns Pre-13D & $\begin{array}{c}0.834 \\
(-1.33)\end{array}$ & $\begin{array}{l}1.087 \\
(0.59)\end{array}$ & $\begin{array}{c}0.833 \\
(-1.49)\end{array}$ & $\begin{array}{c}0.855 \\
(-1.09)\end{array}$ & $\begin{array}{c}0.846 \\
(-1.33)\end{array}$ & $\begin{array}{c}0.811 \\
(-1.00)\end{array}$ \\
\hline \multicolumn{7}{|l|}{ Control Variables } \\
\hline Ln (Market Cap) & $\begin{array}{c}1.208 * * * \\
(4.58)\end{array}$ & $\begin{array}{c}1.193 * * * \\
(2.67)\end{array}$ & $\begin{array}{c}1.124 * * * \\
(3.17)\end{array}$ & $\begin{array}{c}1.203 * * * \\
(3.22)\end{array}$ & $\begin{array}{c}1.215^{* * *} \\
(4.15)\end{array}$ & $\begin{array}{c}1.297 * * * \\
(3.88)\end{array}$ \\
\hline Observations & 1,773 & 1,773 & 2,488 & 2,488 & 1,822 & 1,822 \\
\hline Pseudo R-Squared & 0.104 & 0.104 & 0.0624 & 0.0624 & 0.044 & 0.044 \\
\hline
\end{tabular}


Table 3 (continued)

\begin{tabular}{|c|c|c|c|c|c|c|c|c|}
\hline \multicolumn{9}{|c|}{ Panel B. Incumbents' reputation concerns } \\
\hline Predicted Outcome & Settlement & Proxy Vote & Settlement & Proxy Vote & Settlement & Proxy Vote & Settlement & Proxy Vote \\
\hline Base Outcome & \multicolumn{8}{|c|}{ Campaigns that Neither Lead to a Settlement Nor to a Proxy Vote } \\
\hline & $(1)$ & $(2)$ & $(3)$ & $(4)$ & $(5)$ & $(6)$ & (7) & $(8)$ \\
\hline \multicolumn{9}{|l|}{ Incumbents' Reputation Concerns } \\
\hline \# Directors Older than 70 & $\begin{array}{l}1.067 \\
(1.31)\end{array}$ & $\begin{array}{l}1.141^{*} \\
(1.84)\end{array}$ & & & & & & \\
\hline Directors' Avg \# Directorships & $\begin{array}{c}0.714 * * * \\
(-2.75)\end{array}$ & $\begin{array}{c}0.925 \\
(-0.41)\end{array}$ & & & & & & \\
\hline \# Outside Directors Older than 70 & & & $\begin{array}{l}1.075 \\
(1.38)\end{array}$ & $\begin{array}{l}1.157 * \\
(1.90)\end{array}$ & & & & \\
\hline Outside Directors' Avg \# Directorships & & & $\begin{array}{c}0.732 * * * \\
(-2.87)\end{array}$ & $\begin{array}{c}0.878 \\
(-0.79)\end{array}$ & & & & \\
\hline CEO Up For Election & & & & & $\begin{array}{c}0.713 \\
(-0.85)\end{array}$ & $\begin{array}{l}1.161 \\
(0.37)\end{array}$ & & \\
\hline Board Chair Up For Election & & & & & $\begin{array}{c}2.249^{*} \\
(1.94)\end{array}$ & $\begin{array}{c}0.783 \\
(-0.63)\end{array}$ & & \\
\hline Ln (Analyst Coverage) & & & & & & & $\begin{array}{c}1.483 * * * \\
(4.75)\end{array}$ & $\begin{array}{l}1.016 \\
(0.12)\end{array}$ \\
\hline \multicolumn{9}{|l|}{ Firm Performance } \\
\hline $\mathrm{ROA}$ & $\begin{array}{l}0.588^{*} \\
(-1.67)\end{array}$ & $\begin{array}{c}0.498 \\
(-1.33)\end{array}$ & $\begin{array}{l}0.575^{*} \\
(-1.73)\end{array}$ & $\begin{array}{c}0.487 \\
(-1.35)\end{array}$ & $\begin{array}{c}0.698 \\
(-0.76)\end{array}$ & $\begin{array}{l}1.507 \\
(0.48)\end{array}$ & $\begin{array}{c}0.742 \\
(-0.98)\end{array}$ & $\begin{array}{c}0.603 \\
(-0.99)\end{array}$ \\
\hline Tobin's Q & $\begin{array}{c}0.922 \\
(-1.63)\end{array}$ & $\begin{array}{c}0.987 \\
(-0.23)\end{array}$ & $\begin{array}{c}0.923 \\
(-1.63)\end{array}$ & $\begin{array}{c}0.989 \\
(-0.20)\end{array}$ & $\begin{array}{c}0.951 \\
(-0.61)\end{array}$ & $\begin{array}{l}1.043 \\
(0.42)\end{array}$ & $\begin{array}{l}0.919 * \\
(-1.68)\end{array}$ & $\begin{array}{l}1.020 \\
(0.39)\end{array}$ \\
\hline Abnormal Returns Pre-13D & $\begin{array}{l}0.774 * \\
(-1.92)\end{array}$ & $\begin{array}{c}0.868 \\
(-1.00)\end{array}$ & $\begin{array}{l}0.776 * \\
(-1.91)\end{array}$ & $\begin{array}{c}0.856 \\
(-1.06)\end{array}$ & $\begin{array}{c}0.815 \\
(-0.95)\end{array}$ & $\begin{array}{c}0.974 \\
(-0.36)\end{array}$ & $\begin{array}{c}0.864 \\
(-1.31)\end{array}$ & $\begin{array}{c}0.866 \\
(-1.03)\end{array}$ \\
\hline \multicolumn{9}{|l|}{ Control Variables } \\
\hline Ln (Market Cap) & $\begin{array}{c}1.297 * * * \\
(6.29)\end{array}$ & $\begin{array}{c}1.244 * * * \\
(3.47)\end{array}$ & $\begin{array}{c}1.290 * * * \\
(6.30)\end{array}$ & $\begin{array}{c}1.249 * * * \\
(3.62)\end{array}$ & $\begin{array}{c}1.291 * * * \\
(4.69)\end{array}$ & $\begin{array}{c}1.359 * * * \\
(4.29)\end{array}$ & $\begin{array}{l}1.046 \\
(0.94)\end{array}$ & $\begin{array}{c}1.217 * * \\
(2.54)\end{array}$ \\
\hline Observations & 2,458 & 2,458 & 2,454 & 2,454 & 946 & 946 & 2,488 & 2,488 \\
\hline Pseudo R-Squared & 0.024 & 0.024 & 0.024 & 0.024 & 0.036 & 0.036 & 0.026 & 0.026 \\
\hline
\end{tabular}




\section{Table 4}

The determinants of settlement vs proxy vote.

This table documents the campaign, activist, and target characteristics that predict the occurrence of a settlement agreement versus a proxy vote among the subset of campaigns that lead either to a settlement or a proxy vote. The sample includes hedge fund activism campaigns launched between 2000 and 2013. The sample size differs across models depending on the availability of the independent variables. The models are estimated using multinomial logit regressions. The coefficient estimates represent relative risk ratios. Standard errors are robust to heteroskedasticity; z-statistics appear in parentheses. $* * *, * *$, and * denote statistical significance at the $1 \%, 5 \%$, and $10 \%$ level, respectively (two-tailed). All variables are defined in Appendix A.

\begin{tabular}{|c|c|c|c|c|c|c|c|}
\hline \multirow{3}{*}{$\begin{array}{l}\text { Predicted Outcome } \\
\text { Base Outcome }\end{array}$} & \multicolumn{7}{|c|}{$\frac{\text { Settlement }}{\text { Proxy Vote }}$} \\
\hline & & & & oxy Vot & & & \\
\hline & (1) & (2) & (3) & $(4)$ & (5) & (6) & (7) \\
\hline $\begin{array}{l}\text { Activist Track Record } \\
\text { Market Reaction Past Campaigns }\end{array}$ & $\begin{array}{l}0.901 * \\
(-1.85)\end{array}$ & & & & & & \\
\hline Ln (\# Campaigns) & $\begin{array}{l}1.006 \\
(0.02)\end{array}$ & & & & & & \\
\hline Ln (\# Successful Campaigns) & $\begin{array}{l}1.059 \\
(0.17)\end{array}$ & & & & & & \\
\hline Ln (\# Settlements) & & $\begin{array}{c}2.161 * * * \\
(4.07)\end{array}$ & & & & & \\
\hline Ln (\# Proxy Fights) & & $\begin{array}{c}0.689 * * \\
(-2.23)\end{array}$ & & & & & \\
\hline Ownership Structure & & & & & & & \\
\hline Multiple Share Classes & & & $\begin{array}{c}0.965 \\
(-0.05)\end{array}$ & & & & \\
\hline High Activist Ownership & & & $\begin{array}{l}1.618^{*} \\
(1.86)\end{array}$ & & & & \\
\hline Insider Ownership & & & $\begin{array}{l}4.539 \\
(1.03)\end{array}$ & & & & \\
\hline $\begin{array}{l}\text { Incumbents' Reputation Concerns } \\
\text { \# Directors Older than } 70\end{array}$ & & & & $\begin{array}{c}0.935 \\
(-0.82)\end{array}$ & & & \\
\hline Directors' Avg \# Directorships & & & & $\begin{array}{l}0.772 \\
(-1.20)\end{array}$ & & & \\
\hline \# Outside Directors Older than 70 & & & & & $\begin{array}{c}0.929 \\
(-0.84)\end{array}$ & & \\
\hline Outside Directors' Avg \# Directorships & & & & & $\begin{array}{c}0.834 \\
(-0.97)\end{array}$ & & \\
\hline CEO Up For Election & & & & & & $\begin{array}{c}0.614 \\
(-0.98)\end{array}$ & \\
\hline Board Chair Up For Election & & & & & & $\begin{array}{l}2.874 * * \\
(2.07)\end{array}$ & \\
\hline Ln (Analyst Coverage) & & & & & & & $\begin{array}{c}1.460 * * \\
(2.51)\end{array}$ \\
\hline Firm Performance & & & & & & & \\
\hline ROA & $\begin{array}{l}1.689 \\
(0.74)\end{array}$ & $\begin{array}{l}1.248 \\
(0.37)\end{array}$ & $\begin{array}{l}3.443^{*} \\
(1.82)\end{array}$ & $\begin{array}{l}1.181 \\
(0.28)\end{array}$ & $\begin{array}{l}1.182 \\
(0.28)\end{array}$ & $\begin{array}{c}0.463 \\
(-0.84)\end{array}$ & $\begin{array}{l}1.232 \\
(0.36)\end{array}$ \\
\hline Tobin's Q & $\begin{array}{c}0.839 * * \\
(-2.10)\end{array}$ & $\begin{array}{c}0.911 \\
(-1.35)\end{array}$ & $\begin{array}{l}0.863 \\
(-1.64)\end{array}$ & $\begin{array}{c}0.934 \\
(-0.93)\end{array}$ & $\begin{array}{c}0.933 \\
(-0.96)\end{array}$ & $\begin{array}{l}0.912 \\
(-0.75)\end{array}$ & $\begin{array}{c}0.901 \\
(-1.49)\end{array}$ \\
\hline Abnormal Returns Pre-13D & $\begin{array}{l}0.767 \\
(-1.46)\end{array}$ & $\begin{array}{c}0.974 \\
(-0.14)\end{array}$ & $\begin{array}{l}1.044 \\
(0.18)\end{array}$ & $\begin{array}{c}0.892 \\
(-0.61)\end{array}$ & $\begin{array}{c}0.907 \\
(-0.52)\end{array}$ & $\begin{array}{c}0.837 \\
(-0.80)\end{array}$ & $\begin{array}{c}0.997 \\
(-0.02)\end{array}$ \\
\hline Control Variables & & & & & & & \\
\hline Ln (Market Cap) & $\begin{array}{l}1.013 \\
(0.18)\end{array}$ & $\begin{array}{c}0.935 \\
(-1.05)\end{array}$ & $\begin{array}{c}0.936 \\
(-0.85)\end{array}$ & $\begin{array}{l}1.042 \\
(0.58)\end{array}$ & $\begin{array}{l}1.033 \\
(0.47)\end{array}$ & $\begin{array}{c}0.950 \\
(-0.62)\end{array}$ & $\begin{array}{l}0.859^{*} \\
(-1.75)\end{array}$ \\
\hline Observations & 1,773 & 2,488 & 1,822 & 2,458 & 2,454 & 946 & 2,488 \\
\hline Pseudo R-Squared & 0.104 & 0.062 & 0.044 & 0.024 & 0.024 & 0.036 & 0.026 \\
\hline
\end{tabular}




\section{Table 5}

The content of settlement agreements.

This table outlines the terms specified in settlement agreements between activist hedge funds and their target companies. Panel A tabulates the number of settlement agreements that specify board changes or direct actions. Panel B provides descriptive statistics on individual settlement terms. The frequencies represent the number and percentage of settlement agreements that led to a certain outcome. The averages represent the average number of director additions or departures per settlement. Panel $\mathrm{C}$ compares the number of director departures to the number of director additions. $* * *, * *$, and $*$ denote statistical significance at the $1 \%, 5 \%$, and $10 \%$ level, respectively (twotailed).

\begin{tabular}{lcc}
\hline Panel A. Proxies for board turnover and direct actions & & \\
\hline & \# Settlements & \% Settlements \\
\hline Director Turnover & 342 & 85.71 \\
Sale | Merger | Asset Sale | CEO Departure & 33 & 8.27 \\
Director Turnover Only & 319 & 79.95 \\
Sale | Merger | Asset Sale | CEO Departure Only & 10 & 2.51 \\
Director Turnover \& Sale | Merger | Asset Sale | CEO Departure & 352 & 88.22 \\
\hline
\end{tabular}

Panel B. Individual settlement terms

\begin{tabular}{|c|c|c|c|c|c|}
\hline & \# Settlements & \% Settlements & Average \\
\hline \multirow{2}{*}{\multicolumn{3}{|c|}{$\begin{array}{l}\text { Addition of New Director(s) } \\
\text { Addition of Director(s) Affiliated with Activist }\end{array}$}} & 335 & 83.96 & 1.79 \\
\hline & s) Affiliated with Act & & 207 & 51.88 & 0.65 \\
\hline \multicolumn{3}{|c|}{ Addition of Director(s) Favored by but Unaffiliated with Activist } & 209 & 52.38 & 0.94 \\
\hline \multicolumn{3}{|c|}{ Addition of other Director(s) } & 57 & 14.29 & 0.22 \\
\hline \multicolumn{3}{|c|}{ Director Departure(s) } & 150 & 37.59 & 0.87 \\
\hline \multicolumn{3}{|c|}{ CEO Departure } & 21 & 5.26 & - \\
\hline \multicolumn{3}{|c|}{ Sale or Merger of Target Firm } & 10 & 2.51 & - \\
\hline \multicolumn{3}{|c|}{ Sale of a Part of the Firm's Assets } & 2 & 0.50 & - \\
\hline \multicolumn{3}{|c|}{ Formation of Strategic Transactions Committee } & 23 & 5.76 & - \\
\hline \multicolumn{3}{|c|}{ Exploration of Strategic Alternatives w/o Committee } & 19 & 4.76 & - \\
\hline \multicolumn{3}{|c|}{ Buyback Program Related Announcement } & 21 & 5.26 & - \\
\hline \multicolumn{6}{|c|}{ Panel C. Director additions and departures } \\
\hline $\begin{array}{c}\text { \# Director } \\
\text { Additions per } \\
\text { Settlement } \\
\end{array}$ & $\begin{array}{l}\text { \# Settlements with } \\
0,1,2,3,4,>4 \\
\text { Director Additions }\end{array}$ & $\begin{array}{l}\text { \# Settlements with } \\
\text { Director } \\
\text { Departures } \\
\end{array}$ & $\begin{array}{c}\text { Average \# of } \\
\text { Director Departures }\end{array}$ & \multicolumn{2}{|c|}{$\begin{array}{l}\text { Average Change in } \\
\text { Board Size }\end{array}$} \\
\hline 0 & 64 & 7 & 0.22 & -0.22 & $* *$ \\
\hline 1 & 120 & 21 & 0.30 & 0.70 & $* * *$ \\
\hline 2 & 127 & 53 & 0.59 & 1.41 & $* * *$ \\
\hline 3 & 49 & 37 & 1.80 & 1.20 & $* * *$ \\
\hline 4 & 19 & 13 & 2.26 & 1.74 & $* * *$ \\
\hline $\begin{array}{c}\text { More than } 4 \\
\text { Additions } \\
\text { (Average }=5.8 \text { ) }\end{array}$ & 20 & 19 & 4.50 & 1.30 & $* * *$ \\
\hline
\end{tabular}




\section{Table 6}

Cross-sectional variation in settlement terms.

This table examines cross-sectional differences in settlement terms. Panel A examines whether incumbents' reputation concerns are related to whether director departures and CEO departures are stipulated in the settlement. Panel B tests the relation between information asymmetry between firm insiders and outsiders and the stipulation of actions such as the sale or merger of the firm, the sale of part of the firm's assets, and CEO turnover in the settlement agreement. The sample includes settlements for activism campaigns that are launched between 2000 and 2013 but the number of observations differs with the availability of data on the independent variables. All models are estimated using OLS or linear probability models. Standard errors are robust to heteroskedasticity; t-statistics appear in parentheses. $* * *, * *$, and $*$ denote statistical significance at the $1 \%, 5 \%$, and $10 \%$ level, respectively (two-tailed). All variables are defined in Appendix A.

Panel A. Incumbents' reputation concerns and settlement terms

\begin{tabular}{|c|c|c|c|c|c|c|c|c|}
\hline Dependent Variable & $\begin{array}{c}\text { Director } \\
\text { Departure }\end{array}$ & $\begin{array}{l}\text { \# Director } \\
\text { Departures }\end{array}$ & $\begin{array}{c}\text { Director } \\
\text { Departure }\end{array}$ & $\begin{array}{l}\text { \# Director } \\
\text { Departures }\end{array}$ & $\begin{array}{c}\text { Director } \\
\text { Departure }\end{array}$ & $\begin{array}{l}\text { \# Director } \\
\text { Departures }\end{array}$ & $\begin{array}{c}\text { CEO } \\
\text { Departure }\end{array}$ & $\begin{array}{c}\text { CEO } \\
\text { Departure }\end{array}$ \\
\hline & $(1)$ & $(2)$ & (3) & (4) & $(5)$ & $(6)$ & $(7)$ & $(8)$ \\
\hline \# Directors Older than 70 & $\begin{array}{c}0.083 * * * \\
(3.47)\end{array}$ & $\begin{array}{c}0.170 * * \\
(2.42)\end{array}$ & & & & & & \\
\hline Directors' Average \# Directorships & $\begin{array}{l}-0.007 \\
(-0.09)\end{array}$ & $\begin{array}{l}-0.196 \\
(-1.09)\end{array}$ & & & & & & \\
\hline \# Outside Directors Older than 70 & & & $\begin{array}{c}0.086^{* * * *} \\
(3.32)\end{array}$ & $\begin{array}{c}0.179 * * \\
(2.28)\end{array}$ & & & & \\
\hline Outside Directors' Avg \# Directorships & & & $\begin{array}{l}-0.023 \\
(-0.35)\end{array}$ & $\begin{array}{l}-0.188 \\
(-1.10)\end{array}$ & & & & \\
\hline Ln (Analyst Coverage) & & & & & $\begin{array}{l}-0.005 \\
(-0.10)\end{array}$ & $\begin{array}{l}0.020 \\
(0.14)\end{array}$ & $\begin{array}{l}-0.034 \\
(-1.40)\end{array}$ & \\
\hline CEO Age $>62$ & & & & & & & & $\begin{array}{l}0.077 \\
(1.28)\end{array}$ \\
\hline ROA & $\begin{array}{l}-0.269 \\
(-1.33)\end{array}$ & $\begin{array}{l}-1.012 \\
(-1.40)\end{array}$ & $\begin{array}{l}-0.260 \\
(-1.28)\end{array}$ & $\begin{array}{l}-0.996 \\
(-1.38)\end{array}$ & $\begin{array}{l}-0.187 \\
(-0.93)\end{array}$ & $\begin{array}{l}-0.810 \\
(-1.14)\end{array}$ & $\begin{array}{l}-0.158 \\
(-1.34)\end{array}$ & $\begin{array}{c}-0.373 * * \\
(-2.36)\end{array}$ \\
\hline Tobin's Q & $\begin{array}{l}0.013 \\
(0.70)\end{array}$ & $\begin{array}{l}-0.035 \\
(-0.90)\end{array}$ & $\begin{array}{l}0.012 \\
(0.67)\end{array}$ & $\begin{array}{l}-0.036 \\
(-0.90)\end{array}$ & $\begin{array}{l}0.012 \\
(0.74)\end{array}$ & $\begin{array}{l}-0.033 \\
(-0.96)\end{array}$ & $\begin{array}{l}0.015 \\
(1.35)\end{array}$ & $\begin{array}{l}0.015 \\
(1.48)\end{array}$ \\
\hline Abnormal Returns Pre-13D & $\begin{array}{l}-0.010 \\
(-0.15)\end{array}$ & $\begin{array}{l}-0.004 \\
(-0.02)\end{array}$ & $\begin{array}{l}-0.013 \\
(-0.19)\end{array}$ & $\begin{array}{l}-0.008 \\
(-0.05)\end{array}$ & $\begin{array}{l}0.014 \\
(0.22)\end{array}$ & $\begin{array}{l}0.105 \\
(0.64)\end{array}$ & $\begin{array}{l}-0.002 \\
(-0.09)\end{array}$ & $\begin{array}{l}0.009 \\
(0.33)\end{array}$ \\
\hline Ln (Market Cap) & $\begin{array}{l}-0.008 \\
(-0.42)\end{array}$ & $\begin{array}{l}0.015 \\
(0.27)\end{array}$ & $\begin{array}{l}-0.007 \\
(-0.36)\end{array}$ & $\begin{array}{l}0.013 \\
(0.24)\end{array}$ & $\begin{array}{l}-0.010 \\
(-0.36)\end{array}$ & $\begin{array}{l}-0.026 \\
(-0.33)\end{array}$ & $\begin{array}{c}0.024 * * \\
(1.98)\end{array}$ & $\begin{array}{l}0.010 \\
(1.26)\end{array}$ \\
\hline Industry \& Year FE & Yes & Yes & Yes & Yes & Yes & Yes & Yes & Yes \\
\hline Observations & 335 & 335 & 335 & 335 & 339 & 339 & 339 & 300 \\
\hline R-Squared & 0.170 & 0.239 & 0.169 & 0.239 & 0.139 & 0.218 & 0.252 & 0.279 \\
\hline Adjusted R-Squared & -0.001 & 0.082 & -0.002 & 0.082 & -0.032 & 0.063 & 0.104 & 0.127 \\
\hline
\end{tabular}


Table 6 (continued)

Panel B. Information asymmetry and settlement terms Dependent Variable

\begin{tabular}{|c|c|c|c|c|c|c|c|c|}
\hline & $(1)$ & $(2)$ & $(3)$ & $(4)$ & (5) & $(6)$ & $(7)$ & $(8)$ \\
\hline Cash Flow Volatility & $\begin{array}{c}-0.00004 * * \\
(-2.41)\end{array}$ & $\begin{array}{c}-0.00004 * * \\
(-2.07)\end{array}$ & $\begin{array}{c}-0.00006^{*} \\
(-1.93)\end{array}$ & $\begin{array}{c}-0.00006^{*} \\
(-1.79)\end{array}$ & $\begin{array}{c}-0.00004 * * \\
(-2.50)\end{array}$ & $\begin{array}{c}-0.00004 * \\
(-1.85)\end{array}$ & $\begin{array}{c}-0.00006^{*} \\
(-1.94)\end{array}$ & $\begin{array}{c}-0.00005 \\
(-1.65)\end{array}$ \\
\hline Ln (Market Cap) & & & $\begin{array}{c}0.00859 \\
(0.93)\end{array}$ & $\begin{array}{c}0.00934 \\
(0.88)\end{array}$ & & & $\begin{array}{c}0.00670 \\
(0.64)\end{array}$ & $\begin{array}{c}0.00904 \\
(0.79)\end{array}$ \\
\hline $\mathrm{ROA}$ & & & & & $\begin{array}{c}-0.05306 \\
(-0.35)\end{array}$ & $\begin{array}{c}-0.13359 \\
(-0.88)\end{array}$ & $\begin{array}{c}-0.07566 \\
(-0.47)\end{array}$ & $\begin{array}{c}-0.16228 \\
(-1.04)\end{array}$ \\
\hline Tobin's Q & & & & & $\begin{array}{c}0.02325 * \\
(1.67)\end{array}$ & $\begin{array}{c}0.02278^{*} \\
(1.77)\end{array}$ & $\begin{array}{c}0.02170 \\
(1.57)\end{array}$ & $\begin{array}{c}0.02092 \\
(1.62)\end{array}$ \\
\hline Abnormal Returns Pre-13D & & & & & $\begin{array}{c}-0.00517 \\
(-0.19)\end{array}$ & $\begin{array}{c}-0.00342 \\
(-0.12)\end{array}$ & $\begin{array}{c}-0.00417 \\
(-0.15)\end{array}$ & $\begin{array}{c}-0.00196 \\
(-0.07)\end{array}$ \\
\hline Industry \& Year FE & No & Yes & No & Yes & No & Yes & No & Yes \\
\hline Observations & 310 & 290 & 310 & 290 & 306 & 286 & 306 & 286 \\
\hline R-Squared & 0.003 & 0.255 & 0.006 & 0.257 & 0.027 & 0.282 & 0.028 & 0.284 \\
\hline Adjusted R-Squared & 0.000 & 0.117 & -0.001 & 0.117 & 0.014 & 0.136 & 0.012 & 0.135 \\
\hline
\end{tabular}




\section{Table 7}

Board turnover around settlement agreements.

This table presents difference-in-differences analyses of board turnover around settlement agreements. Columns 1 to 3 examine the number of new directors on the board and models 4 to 6 the number of director departures. For target firms that settle ("Settled Campaigns"; all columns), we select untargeted control firms by propensity-score-matching on the year that the settlement agreement is reached. For target firms that experience a proxy contest vote (columns 3 and 6), we select untargeted control firms by propensity-score-matching on the proxy contest announcement year. For target firms that experience neither settlement nor proxy contest vote ("Other Campaigns"; columns 2,3,5,6), we select untargeted control firms by propensity-score-matching on the year of the initial activism announcement which, in most cases, is the year of the first 13D filing. The tabulated coefficients measure how the difference between treatment firm board turnover and control firm board turnover has changed from the year before treatment/placebo (the omitted base year) to year $\mathrm{s} \pm \mathrm{k}, \mathrm{t} \pm \mathrm{k}$, or $\mathrm{c} \pm \mathrm{k}$. Treatment can either be the settlement year (for settled campaigns) or the proxy fight announcement year (for those proxy fights that went to a vote) or the year of the initial activism announcement (for "Other Campaigns" and "All Campaigns"). Columns 2, 3, 5, and 6 (columns 3 and 6) include dummies for the Settlement (Voted Proxy) main effect. All columns include a set of $11 \mathrm{~d}[\mathrm{~s} \pm \mathrm{k}]$ dummies, one for each year relative to the settlement year (for treatment firms) and matched placebo year (for control firms). In addition, columns 2, 3, 5, 6 (columns 3 and 6) include a set of $11 \mathrm{~d}[\mathrm{t} \pm \mathrm{k}](\mathrm{d}[\mathrm{c} \pm \mathrm{k}])$ dummies, one for each year relative to the initial campaign launch year (proxy fight announcement year) and matched placebo year. At the bottom of the table, p-values of partial F-tests indicate the statistical significance of difference-in-differences estimations of board turnover around settlement agreements using year $t-2$ as the base year. Coefficients and standard errors clustered by firm are estimated using OLS. T-statistics appear in parentheses. ***, **,* denote statistical significance at the 1\%,5\%, and 10\% level, respectively (two-tailed). All variables are defined in Appendix A.

\begin{tabular}{|c|c|c|c|c|c|c|}
\hline \multirow{2}{*}{$\begin{array}{l}\text { Dependent Variable } \\
\text { Sample }\end{array}$} & \multicolumn{3}{|c|}{ \# Director Additions } & \multicolumn{3}{|c|}{ \# Director Departures } \\
\hline & $\begin{array}{c}\text { Settled } \\
\text { Campaigns \& } \\
\text { Control Firms }\end{array}$ & $\begin{array}{c}\text { Settled } \\
\text { Campaigns, } \\
\text { Other } \\
\text { Campaigns \& } \\
\text { Control Firms } \\
\end{array}$ & $\begin{array}{c}\text { All } \\
\text { Campaigns \& } \\
\text { Control Firms }\end{array}$ & $\begin{array}{c}\text { Settled } \\
\text { Campaigns \& } \\
\text { Control Firms }\end{array}$ & $\begin{array}{c}\text { Settled } \\
\text { Campaigns, } \\
\text { Other } \\
\text { Campaigns \& } \\
\text { Control Firms } \\
\end{array}$ & $\begin{array}{c}\text { All } \\
\text { Campaigns \& } \\
\text { Control Firms }\end{array}$ \\
\hline & $(1)$ & $(2)$ & $(3)$ & $(4)$ & $(5)$ & $(6)$ \\
\hline Settlement $\cdot d[s-5]$ & $\begin{array}{c}-0.207 * * \\
(-1.99)\end{array}$ & $\begin{array}{l}-0.110 \\
(-1.06)\end{array}$ & $\begin{array}{l}-0.135 \\
(-1.34)\end{array}$ & $\begin{array}{l}-0.087 \\
(-0.81)\end{array}$ & $\begin{array}{l}-0.058 \\
(-0.55)\end{array}$ & $\begin{array}{l}-0.063 \\
(-0.62)\end{array}$ \\
\hline Settlement $\cdot d[s-4]$ & $\begin{array}{l}-0.003 \\
(-0.02)\end{array}$ & $\begin{array}{l}0.082 \\
(0.70)\end{array}$ & $\begin{array}{l}0.057 \\
(0.52)\end{array}$ & $\begin{array}{l}-0.110 \\
(-1.05)\end{array}$ & $\begin{array}{l}-0.087 \\
(-0.85)\end{array}$ & $\begin{array}{l}-0.092 \\
(-0.94)\end{array}$ \\
\hline Settlement $\cdot d[s-3]$ & $\begin{array}{l}-0.158 \\
(-1.55)\end{array}$ & $\begin{array}{l}-0.102 \\
(-1.01)\end{array}$ & $\begin{array}{l}-0.124 \\
(-1.29)\end{array}$ & $\begin{array}{l}-0.033 \\
(-0.32)\end{array}$ & $\begin{array}{l}-0.022 \\
(-0.22)\end{array}$ & $\begin{array}{l}-0.021 \\
(-0.21)\end{array}$ \\
\hline Settlement $\cdot d[s-2]$ & $\begin{array}{l}-0.116 \\
(-0.95)\end{array}$ & $\begin{array}{l}-0.098 \\
(-0.82)\end{array}$ & $\begin{array}{l}-0.117 \\
(-1.02)\end{array}$ & $\begin{array}{l}-0.071 \\
(-0.64)\end{array}$ & $\begin{array}{l}-0.090 \\
(-0.85)\end{array}$ & $\begin{array}{l}-0.087 \\
(-0.86)\end{array}$ \\
\hline Settlement $\cdot \mathrm{d}[\mathrm{s}]$ & $\begin{array}{c}1.399 * * * \\
(9.51)\end{array}$ & $\begin{array}{c}1.299 * * * \\
(9.00)\end{array}$ & $\begin{array}{c}1.270 * * * \\
(9.02)\end{array}$ & $\begin{array}{c}0.840 * * * \\
(6.49)\end{array}$ & $\begin{array}{c}0.742 * * * \\
(5.88)\end{array}$ & $\begin{array}{c}0.743 * * * \\
(6.04)\end{array}$ \\
\hline Settlement $\cdot \mathrm{d}[\mathrm{s}+1]$ & $\begin{array}{c}0.328 * * \\
(2.48)\end{array}$ & $\begin{array}{c}0.237 * \\
(1.87)\end{array}$ & $\begin{array}{c}0.215^{*} \\
(1.74)\end{array}$ & $\begin{array}{c}0.375 * * * \\
(2.78)\end{array}$ & $\begin{array}{c}0.256^{*} \\
(1.94)\end{array}$ & $\begin{array}{c}0.253^{* *} \\
(1.97)\end{array}$ \\
\hline Settlement $\cdot d[s+2]$ & $\begin{array}{l}0.147 \\
(1.00)\end{array}$ & $\begin{array}{l}0.119 \\
(0.84)\end{array}$ & $\begin{array}{l}0.100 \\
(0.73)\end{array}$ & $\begin{array}{c}0.493 * * * \\
(2.90)\end{array}$ & $\begin{array}{c}0.416^{* *} \\
(2.58)\end{array}$ & $\begin{array}{c}0.414 * * * \\
(2.63)\end{array}$ \\
\hline Settlement $\cdot \mathrm{d}[\mathrm{s}+3]$ & $\begin{array}{l}0.008 \\
(0.06)\end{array}$ & $\begin{array}{l}0.023 \\
(0.16)\end{array}$ & $\begin{array}{l}-0.002 \\
(-0.02)\end{array}$ & $\begin{array}{l}0.185 \\
(1.29)\end{array}$ & $\begin{array}{l}0.165 \\
(1.20)\end{array}$ & $\begin{array}{l}0.160 \\
(1.17)\end{array}$ \\
\hline Settlement $\cdot d[s+4]$ & $\begin{array}{l}0.055 \\
(0.26)\end{array}$ & $\begin{array}{l}0.064 \\
(0.32)\end{array}$ & $\begin{array}{l}0.039 \\
(0.19)\end{array}$ & $\begin{array}{l}0.191 \\
(0.82)\end{array}$ & $\begin{array}{l}0.169 \\
(0.76)\end{array}$ & $\begin{array}{l}0.160 \\
(0.73)\end{array}$ \\
\hline Settlement $\cdot d[s+5]$ & $\begin{array}{l}0.000 \\
(0.00)\end{array}$ & $\begin{array}{l}-0.008 \\
(-0.05)\end{array}$ & $\begin{array}{l}-0.030 \\
(-0.17)\end{array}$ & $\begin{array}{l}0.082 \\
(0.44)\end{array}$ & $\begin{array}{l}0.043 \\
(0.24)\end{array}$ & $\begin{array}{l}0.035 \\
(0.20)\end{array}$ \\
\hline $13 \mathrm{D} \cdot \mathrm{d}[\mathrm{t}-5]$ & & $\begin{array}{c}-0.095^{*} \\
(-1.73)\end{array}$ & $\begin{array}{l}-0.083 \\
(-1.54)\end{array}$ & & $\begin{array}{l}-0.068 \\
(-1.28)\end{array}$ & $\begin{array}{l}-0.065 \\
(-1.23)\end{array}$ \\
\hline $13 \mathrm{D} \cdot \mathrm{d}[\mathrm{t}-4]$ & & $\begin{array}{l}-0.054 \\
(-1.04)\end{array}$ & $\begin{array}{l}-0.037 \\
(-0.73)\end{array}$ & & $\begin{array}{l}-0.047 \\
(-0.93)\end{array}$ & $\begin{array}{l}-0.035 \\
(-0.71)\end{array}$ \\
\hline $13 \mathrm{D} \cdot \mathrm{d}[\mathrm{t}-3]$ & & $\begin{array}{l}-0.065 \\
(-1.38)\end{array}$ & $\begin{array}{l}-0.055 \\
(-1.18)\end{array}$ & & $\begin{array}{l}-0.050 \\
(-1.05)\end{array}$ & $\begin{array}{l}-0.046 \\
(-0.97)\end{array}$ \\
\hline $13 \mathrm{D} \cdot \mathrm{d}[\mathrm{t}-2]$ & & $\begin{array}{l}-0.015 \\
(-0.31)\end{array}$ & $\begin{array}{l}-0.003 \\
(-0.06)\end{array}$ & & $\begin{array}{l}-0.040 \\
(-0.84)\end{array}$ & $\begin{array}{l}-0.043 \\
(-0.93)\end{array}$ \\
\hline $13 \mathrm{D} \cdot \mathrm{d}[\mathrm{t}]$ & & $\begin{array}{c}0.101 * * \\
(2.01)\end{array}$ & $\begin{array}{c}0.112 * * \\
(2.29)\end{array}$ & & $\begin{array}{l}0.078 \\
(1.63)\end{array}$ & $\begin{array}{l}0.070 \\
(1.49) \\
\end{array}$ \\
\hline
\end{tabular}


Table 7 (continued)

\begin{tabular}{|c|c|c|c|c|c|c|}
\hline \multicolumn{2}{|l|}{$13 \mathrm{D} \cdot \mathrm{d}[\mathrm{t}+1]$} & $\begin{array}{c}0.171 * * * \\
(3.23)\end{array}$ & $\begin{array}{c}0.201 * * * \\
(3.86)\end{array}$ & & $\begin{array}{l}0.068 \\
(1.32)\end{array}$ & $\begin{array}{l}0.076 \\
(1.51)\end{array}$ \\
\hline \multicolumn{2}{|l|}{$13 \mathrm{D} \cdot \mathrm{d}[\mathrm{t}+2]$} & $\begin{array}{c}0.125 * * \\
(2.23)\end{array}$ & $\begin{array}{c}0.114 * * \\
(2.08)\end{array}$ & & $\begin{array}{c}0.150 * * \\
(2.36)\end{array}$ & $\begin{array}{c}0.149 * * \\
(2.39)\end{array}$ \\
\hline \multicolumn{2}{|l|}{$13 \mathrm{D} \cdot \mathrm{d}[\mathrm{t}+3]$} & $\begin{array}{l}-0.004 \\
(-0.06)\end{array}$ & $\begin{array}{l}0.006 \\
(0.12)\end{array}$ & & $\begin{array}{l}-0.038 \\
(-0.68)\end{array}$ & $\begin{array}{l}-0.042 \\
(-0.74)\end{array}$ \\
\hline \multicolumn{2}{|l|}{$13 \mathrm{D} \cdot \mathrm{d}[\mathrm{t}+4]$} & $\begin{array}{l}-0.009 \\
(-0.15)\end{array}$ & $\begin{array}{l}0.008 \\
(0.13)\end{array}$ & & $\begin{array}{l}-0.012 \\
(-0.18)\end{array}$ & $\begin{array}{l}0.001 \\
(0.02)\end{array}$ \\
\hline $13 \mathrm{D} \cdot \mathrm{d}[\mathrm{t}+5]$ & & $\begin{array}{l}0.038 \\
(0.61)\end{array}$ & $\begin{array}{l}0.054 \\
(0.88)\end{array}$ & & $\begin{array}{l}-0.028 \\
(-0.46)\end{array}$ & $\begin{array}{l}-0.018 \\
(-0.30)\end{array}$ \\
\hline Voted Contest $\cdot \mathrm{d}[\mathrm{c}-5]$ & & & $\begin{array}{c}0.435 * * \\
(2.20)\end{array}$ & & & $\begin{array}{l}0.286 \\
(1.41)\end{array}$ \\
\hline Voted Contest $\cdot \mathrm{d}[\mathrm{c}-4]$ & & & $\begin{array}{l}-0.125 \\
(-0.90)\end{array}$ & & & $\begin{array}{l}-0.025 \\
(-0.17)\end{array}$ \\
\hline Voted Contest $\cdot \mathrm{d}[\mathrm{c}-3]$ & & & $\begin{array}{l}0.005 \\
(0.03)\end{array}$ & & & $\begin{array}{c}0.307 * \\
(1.74)\end{array}$ \\
\hline Voted Contest $\cdot \mathrm{d}[\mathrm{c}-2]$ & & & $\begin{array}{l}0.120 \\
(0.78)\end{array}$ & & & $\begin{array}{l}0.101 \\
(0.78)\end{array}$ \\
\hline Voted Contest $\cdot \mathrm{d}[\mathrm{c}]$ & & & $\begin{array}{l}0.191 \\
(1.14)\end{array}$ & & & $\begin{array}{c}0.339 * * \\
(2.18)\end{array}$ \\
\hline Voted Contest $\cdot \mathrm{d}[\mathrm{c}+1]$ & & & $\begin{array}{c}1.421 * * * \\
(5.85)\end{array}$ & & & $\begin{array}{c}1.076^{* * * *} \\
(4.44)\end{array}$ \\
\hline Voted Contest $\cdot \mathrm{d}[\mathrm{c}+2]$ & & & $\begin{array}{l}0.226 \\
(1.31)\end{array}$ & & & $\begin{array}{c}0.807 * * * \\
(3.03)\end{array}$ \\
\hline Voted Contest $\cdot \mathrm{d}[\mathrm{c}+3]$ & & & $\begin{array}{l}-0.073 \\
(-0.49)\end{array}$ & & & $\begin{array}{l}0.192 \\
(1.09)\end{array}$ \\
\hline Voted Contest $\cdot \mathrm{d}[\mathrm{c}+4]$ & & & $\begin{array}{l}0.254 \\
(1.15)\end{array}$ & & & $\begin{array}{l}0.230 \\
(1.02)\end{array}$ \\
\hline Voted Contest $\cdot \mathrm{d}[\mathrm{c}+5]$ & & & $\begin{array}{l}-0.043 \\
(-0.19)\end{array}$ & & & $\begin{array}{l}0.008 \\
(0.04)\end{array}$ \\
\hline Firm \& Year FE & Yes & Yes & Yes & Yes & Yes & Yes \\
\hline Observations & 12,922 & 80,864 & 85,867 & 12,922 & 80,864 & 85,867 \\
\hline Adjusted R-Squared & 0.150 & 0.183 & 0.184 & 0.157 & 0.197 & 0.197 \\
\hline \multicolumn{7}{|c|}{ P-Values for Partial F-Tests Comparing Coefficients } \\
\hline $\mathrm{S} \cdot \mathrm{d}[\mathrm{s}]$ vs. $\mathrm{S} \cdot \mathrm{d}[\mathrm{s}-2]$ & 0.000 & 0.000 & 0.000 & 0.000 & 0.000 & 0.000 \\
\hline $\mathrm{S} \cdot \mathrm{d}[\mathrm{s}+1]$ vs. $\mathrm{S} \cdot \mathrm{d}[\mathrm{s}-2]$ & 0.001 & 0.011 & 0.012 & 0.002 & 0.016 & 0.018 \\
\hline $\mathrm{S} \cdot \mathrm{d}[\mathrm{s}+2]$ vs. $\mathrm{S} \cdot \mathrm{d}[\mathrm{s}-2]$ & 0.071 & 0.127 & 0.126 & 0.000 & 0.001 & 0.001 \\
\hline $\mathrm{S} \cdot \mathrm{d}[\mathrm{s}+3]$ vs. $\mathrm{S} \cdot \mathrm{d}[\mathrm{s}-2]$ & 0.407 & 0.407 & 0.431 & 0.114 & 0.105 & 0.117 \\
\hline $\mathrm{S} \cdot \mathrm{d}[\mathrm{s}+4]$ vs. $\mathrm{S} \cdot \mathrm{d}[\mathrm{s}-2]$ & 0.445 & 0.448 & 0.467 & 0.267 & 0.248 & 0.270 \\
\hline $\mathrm{S} \cdot \mathrm{d}[\mathrm{s}+5]$ vs. $\mathrm{S} \cdot \mathrm{d}[\mathrm{s}-2]$ & 0.546 & 0.627 & 0.638 & 0.402 & 0.449 & 0.483 \\
\hline
\end{tabular}




\section{Table 8}

Activist-favored directors following settlement agreements.

This table documents the annual probability of activist-affiliated (column 1), activist favored but unaffiliated (column 2), and other directors (column 3) being added to the boards of activism target companies following settlement agreements. Since hedge fund activists unlikely place directors on the boards of untargeted companies, this analysis excludes control firms and target firm-years prior to the intervention. The time period identifiers measure the annual level of the dependent variable relative to the average level among activism targets in years 3 to 5 following the activist intervention. Coefficients and standard errors clustered by firm are estimated using linear probability models. T-statistics appear in parentheses. ***, **, * denote statistical significance at the $1 \%, 5 \%$, and $10 \%$ level, respectively (two-tailed). All variables are defined in Appendix A.

\begin{tabular}{|c|c|c|c|c|c|c|c|c|c|}
\hline \multirow{3}{*}{$\begin{array}{l}\text { Dependent Variable } \\
\text { Sample }\end{array}$} & \multicolumn{3}{|c|}{ Prob (Favored and Affiliated Director) } & \multicolumn{3}{|c|}{ Prob (Favored but Unaffiliated Director) } & \multicolumn{3}{|c|}{ Prob (Other New Director) } \\
\hline & $\begin{array}{c}\text { Settled } \\
\text { Campaigns }\end{array}$ & $\begin{array}{c}\text { Settled } \\
\text { Campaigns } \\
\text { \& Other } \\
\text { Campaigns }\end{array}$ & $\begin{array}{c}\text { All } \\
\text { Campaigns }\end{array}$ & $\begin{array}{c}\text { Settled } \\
\text { Campaigns }\end{array}$ & $\begin{array}{c}\text { Settled } \\
\text { Campaigns } \\
\text { \& Other } \\
\text { Campaigns }\end{array}$ & $\begin{array}{c}\text { All } \\
\text { Campaigns }\end{array}$ & $\begin{array}{c}\text { Settled } \\
\text { Campaigns }\end{array}$ & $\begin{array}{c}\text { Settled } \\
\text { Campaigns } \\
\text { \& Other } \\
\text { Campaigns }\end{array}$ & $\begin{array}{c}\text { All } \\
\text { Campaigns }\end{array}$ \\
\hline & $(1)$ & $(2)$ & $(3)$ & $(4)$ & $(5)$ & $(6)$ & $(7)$ & $(8)$ & $(9)$ \\
\hline Settlement $\cdot \mathrm{d}[\mathrm{s}]$ & $\begin{array}{c}0.240 * * * \\
(3.10)\end{array}$ & $\begin{array}{c}0.186^{* * * *} \\
(6.11)\end{array}$ & $\begin{array}{c}0.187 * * * \\
(6.41)\end{array}$ & $\begin{array}{l}0.194 \\
(1.63)\end{array}$ & $\begin{array}{c}0.302 * * * \\
(6.73)\end{array}$ & $\begin{array}{c}0.306^{* * * *} \\
(7.00)\end{array}$ & $\begin{array}{c}-0.443 * * \\
(-2.43)\end{array}$ & $\begin{array}{c}-0.492 * * * \\
(-8.34)\end{array}$ & $\begin{array}{c}-0.500 * * * \\
(-8.59)\end{array}$ \\
\hline Settlement $\cdot d[s+1]$ & $\begin{array}{l}0.076 \\
(1.00)\end{array}$ & $\begin{array}{l}0.037 \\
(0.84)\end{array}$ & $\begin{array}{l}0.046 \\
(1.07)\end{array}$ & $\begin{array}{l}0.079 \\
(0.70)\end{array}$ & $\begin{array}{c}0.155 * * * \\
(3.02)\end{array}$ & $\begin{array}{c}0.165 * * * \\
(3.27)\end{array}$ & $\begin{array}{l}-0.160 \\
(-1.01)\end{array}$ & $\begin{array}{c}-0.194 * * * \\
(-3.17)\end{array}$ & $\begin{array}{c}-0.213 * * * \\
(-3.56)\end{array}$ \\
\hline Settlement $\cdot d[s+2]$ & $\begin{array}{l}-0.023 \\
(-0.31)\end{array}$ & $\begin{array}{c}-0.070 * * \\
(-2.52)\end{array}$ & $\begin{array}{c}-0.067 * * \\
(-2.50)\end{array}$ & $\begin{array}{l}0.004 \\
(0.03)\end{array}$ & $\begin{array}{l}0.035 \\
(0.97)\end{array}$ & $\begin{array}{l}0.028 \\
(0.74)\end{array}$ & $\begin{array}{l}0.016 \\
(0.09)\end{array}$ & $\begin{array}{l}0.034 \\
(0.84)\end{array}$ & $\begin{array}{l}0.038 \\
(0.92)\end{array}$ \\
\hline $13 \mathrm{D} \cdot \mathrm{d}[\mathrm{t}]$ & & $\begin{array}{l}0.095 * * * \\
(4.20)\end{array}$ & $\begin{array}{c}0.092 * * * \\
(4.22)\end{array}$ & & $\begin{array}{c}0.057 * * \\
(2.15)\end{array}$ & $\begin{array}{l}0.021 \\
(0.76)\end{array}$ & & $\begin{array}{c}-0.148 * * * \\
(-3.93)\end{array}$ & $\begin{array}{c}-0.109 * * * \\
(-2.82)\end{array}$ \\
\hline $13 \mathrm{D} \cdot \mathrm{d}[\mathrm{t}+1]$ & & $\begin{array}{c}0.069 * * * \\
(3.94)\end{array}$ & $\begin{array}{c}0.070 * * * \\
(4.04)\end{array}$ & & $\begin{array}{l}0.026 \\
(1.64)\end{array}$ & $\begin{array}{l}0.000 \\
(0.00)\end{array}$ & & $\begin{array}{c}-0.091 * * * \\
(-3.67)\end{array}$ & $\begin{array}{c}-0.065^{* *} \\
(-2.36)\end{array}$ \\
\hline $13 \mathrm{D} \cdot \mathrm{d}[\mathrm{t}+2]$ & & $\begin{array}{c}0.043 * * \\
(2.45)\end{array}$ & $\begin{array}{c}0.036 * * \\
(2.08)\end{array}$ & & $\begin{array}{l}0.030 * * \\
(2.13)\end{array}$ & $\begin{array}{l}0.003 \\
(0.17)\end{array}$ & & $\begin{array}{c}-0.069 * * * \\
(-2.93)\end{array}$ & $\begin{array}{l}-0.035 \\
(-1.35)\end{array}$ \\
\hline Voted Contest $\cdot \mathrm{d}[\mathrm{c}]$ & & & $\begin{array}{c}0.118 * * \\
(2.08)\end{array}$ & & & $\begin{array}{l}0.256^{* * * *} \\
(4.29)\end{array}$ & & & $\begin{array}{c}-0.360 * * * \\
(-3.74)\end{array}$ \\
\hline Voted Contest $\cdot \mathrm{d}[\mathrm{c}+1]$ & & & $\begin{array}{l}0.119 * * * \\
(2.72)\end{array}$ & & & $\begin{array}{l}0.210 * * * \\
(4.04)\end{array}$ & & & $\begin{array}{c}-0.324 * * * \\
(-4.26)\end{array}$ \\
\hline Voted Contest $\cdot \mathrm{d}[\mathrm{c}+2]$ & & & $\begin{array}{l}0.055 \\
(1.41)\end{array}$ & & & $\begin{array}{l}0.084 \\
(1.39)\end{array}$ & & & $\begin{array}{l}-0.120 \\
(-1.39)\end{array}$ \\
\hline Firm \& Year FE & Yes & Yes & Yes & Yes & Yes & Yes & Yes & Yes & Yes \\
\hline Observations & 792 & 3,059 & 3,369 & 792 & 3,059 & 3,369 & 792 & 3,059 & 3,369 \\
\hline Adjusted R-Squared & 0.058 & 0.104 & 0.102 & 0.170 & 0.259 & 0.257 & 0.223 & 0.324 & 0.329 \\
\hline
\end{tabular}




\section{Table 9}

Board renewal around settlement agreements.

This table presents triple-difference analyses of the relation between director characteristics and the probability of director turnover around settlement agreements. Columns 1 to 3 examine additions of new directors and columns 4 to 6 departures of incumbent directors. For target firms that settle ("Settled Campaigns"; all columns), we select untargeted control firms by propensity-score-matching on the year that the settlement agreement is reached. For target firms that experience a proxy contest vote (columns 3 and 6), we select untargeted control firms by propensity-score-matching on the proxy contest announcement year. For target firms that experience neither settlement nor proxy contest vote ("Other Campaigns"; columns 2, 3, 5,6), we select untargeted control firms by propensity-scorematching on the year of the initial activism announcement (in most cases the year of the first 13D filing). The tabulated coefficients measure how the difference between treatment firms and control firms in the relation between director characteristics and director turnover changes from the three years before treatment/placebo $(\mathrm{POST}=0)$ to the year of and the two years following treatment/placebo (POST=1). Treatment can either be the settlement year (for settled campaigns) or the proxy fight announcement year (for those proxy fights that went to a vote) or the year of the initial activism announcement (for "Other Campaigns" and "All Campaigns"). Columns 2, 3, 5, and 6 (columns 3 and 6) include dummies for the Settlement (Voted Proxy) main effect. All columns include a dummy variable d[POSTS] that is equal to 1 in the year of and the two years following the settlement year (for treatment firms) or placebo year (for control firms) and equal to 0 in the three years prior to the settlement or placebo. In addition, columns 2 and 3 (column 3 ) include another d[POSTD] (d[POSTC]) dummy that is equal to 1 in the year of and the two years following the initial intervention year or matched placebo year (proxy fight announcement year or matched placebo year) and equal to zero in the three years prior to the initial intervention year or placebo year (proxy fight announcement year or placebo year). All columns include the main effects for the different director characteristics. All relevant two-way interactions are included. Coefficients and standard errors clustered by firm are estimated using linear probability models. T-statistics appear in parentheses. $* * *, * *, *$ denote statistical significance at the $1 \%, 5 \%$, and $10 \%$ level, respectively (two-tailed). All variables are defined in Appendix A.

\begin{tabular}{|c|c|c|c|c|c|c|}
\hline \multirow{2}{*}{$\begin{array}{l}\text { Dependent Variable } \\
\text { Sample }\end{array}$} & \multicolumn{3}{|c|}{ Prob (Director Addition) } & \multicolumn{3}{|c|}{ Prob (Director Departure) } \\
\hline & $\begin{array}{c}\text { Settled } \\
\text { Campaigns \& } \\
\text { Control Firms }\end{array}$ & $\begin{array}{c}\text { Settled } \\
\text { Campaigns, } \\
\text { Other Campaigns } \\
\text { \& Control Firms }\end{array}$ & $\begin{array}{l}\text { All Campaigns \& } \\
\text { Control Firms }\end{array}$ & $\begin{array}{c}\text { Settled } \\
\text { Campaigns \& } \\
\text { Control Firms }\end{array}$ & $\begin{array}{c}\text { Settled } \\
\text { Campaigns, } \\
\text { Other Campaigns } \\
\text { \& Control Firms }\end{array}$ & $\begin{array}{l}\text { All Campaigns \& } \\
\text { Control Firms }\end{array}$ \\
\hline & (1) & $(2)$ & (3) & (4) & $(5)$ & $(6)$ \\
\hline Settlement $\cdot \mathrm{d}[\mathrm{POSTS}] \cdot$ Age $>70$ & $\begin{array}{c}-0.047 * * * \\
(-2.87)\end{array}$ & $\begin{array}{c}-0.037 * * \\
(-2.38)\end{array}$ & $\begin{array}{c}-0.037 * * \\
(-2.40)\end{array}$ & $\begin{array}{l}-0.031 \\
(-0.98)\end{array}$ & $\begin{array}{l}-0.044 \\
(-1.47)\end{array}$ & $\begin{array}{l}-0.046 \\
(-1.58)\end{array}$ \\
\hline Settlement $\cdot \mathrm{d}[\mathrm{POSTS}] \cdot$ Connectedness & $\begin{array}{c}0.011^{*} \\
(1.85)\end{array}$ & $\begin{array}{l}0.010^{*} \\
(1.78)\end{array}$ & $\begin{array}{l}0.010^{*} \\
(1.83)\end{array}$ & $\begin{array}{l}-0.002 \\
(-0.37)\end{array}$ & $\begin{array}{l}-0.002 \\
(-0.44)\end{array}$ & $\begin{array}{l}-0.002 \\
(-0.35)\end{array}$ \\
\hline Settlement $\cdot \mathrm{d}[$ POSTS $] \cdot$ Tenure & & & & $\begin{array}{l}0.003 * * \\
(2.34)\end{array}$ & $\begin{array}{l}0.003^{* *} \\
(2.29)\end{array}$ & $\begin{array}{l}0.003 * * \\
(2.48)\end{array}$ \\
\hline $13 \mathrm{D} \cdot \mathrm{d}[\mathrm{POSTD}] \cdot \mathrm{Age}>70$ & & $\begin{array}{l}-0.009 \\
(-1.56)\end{array}$ & $\begin{array}{l}-0.010^{*} \\
(-1.85)\end{array}$ & & $\begin{array}{l}0.009 \\
(0.78)\end{array}$ & $\begin{array}{l}0.012 \\
(1.00)\end{array}$ \\
\hline 13D $\cdot \mathrm{d}[\mathrm{POSTD}] \cdot$ Connectedness & & $\begin{array}{l}0.004 * * \\
(2.27)\end{array}$ & $\begin{array}{l}0.004 * * \\
(2.08)\end{array}$ & & $\begin{array}{l}-0.000 \\
(-0.10)\end{array}$ & $\begin{array}{l}-0.001 \\
(-0.46)\end{array}$ \\
\hline $13 \mathrm{D} \cdot \mathrm{d}[\mathrm{POSTD}] \cdot$ Tenure & & & & & $\begin{array}{l}0.000 \\
(0.55) \\
\end{array}$ & $\begin{array}{l}0.000 \\
(0.19) \\
\end{array}$ \\
\hline
\end{tabular}




\section{Table 9 (continued)}

Voted Contest $\cdot \mathrm{d}[$ POSTC $] \cdot$ Age $>70$

$-0.029 *$

$(-1.69)$

0.002

$-0.006$

Voted Contest $\cdot \mathrm{d}[$ POSTC $] \cdot$ Connectedness

(0.40)

$(-0.14)$

$-0.010^{*}$

$(-1.65)$

Voted Contest $\cdot \mathrm{d}[$ POSTC $] \cdot$ Tenure

$0.007 * *$

Firm \& Year FE

Observations

Yes

66,054

Yes

386,402

362,992

0.040

Yes

66,054

(3.26)

0.033

0.040

0.041

Yes
362.992

(0.043

Yes

386,402

Adjusted R-Squared 


\section{Table 10}

Market reaction to settlement agreements.

This table documents the stock market reaction to settlement agreements. Panel A shows the average market reaction and Panel B examines the determinants of the market reaction. The stock market reaction is measured over a 5-day window and a 7-day window centered on the date on which the settlement agreement is filed. We measure the buy and hold return on the target firm over these windows relative to the buy and hold return on the value-weighted market index. The sample includes settlements for activism campaigns that are launched between 2000 and 2013 and for which we have information on the market reaction and control variables. Coefficients and heteroskedasticity-robust standard errors are estimated using OLS. T-statistics appear in parentheses. ***,**,* denote statistical significance at the $1 \%, 5 \%$, and $10 \%$ level, respectively (two-tailed). All variables are defined in Appendix A.

\section{Panel A: Average market reaction}

\begin{tabular}{lccc} 
& \multicolumn{2}{c}{ Buy-and-Hold Abnormal Return } \\
\cline { 2 - 4 } Event window & Average & Observations & Standard error \\
$(\mathrm{t}-2, \mathrm{t}+2)$ & $1.16 \%$ & 374 & 0.0043 \\
$(\mathrm{t}-3, \mathrm{t}+3)$ & $1.28 \%$ & 374 & 0.0049 \\
\hline
\end{tabular}

Panel B. Determinants of the market reaction

\begin{tabular}{|c|c|c|c|c|c|c|c|c|}
\hline \multirow[b]{3}{*}{ High Board Turnover } & \multicolumn{4}{|c|}{ Buy-and-Hold Abnormal Return (t-2, t+2) } & \multicolumn{4}{|c|}{ Buy-and-Hold Abnormal Return $(\mathrm{t}-3, \mathrm{t}+3)$} \\
\hline & $(1)$ & $(2)$ & (3) & (4) & $(5)$ & $(6)$ & $(7)$ & (8) \\
\hline & $\begin{array}{c}0.020 * \\
(1.87)\end{array}$ & & & & $\begin{array}{c}0.021 * \\
(1.65)\end{array}$ & & & \\
\hline CEO Departure & & $\begin{array}{l}0.026 \\
(1.20)\end{array}$ & & & & $\begin{array}{l}0.027 \\
(1.16)\end{array}$ & & \\
\hline Strategic Transaction & & & $\begin{array}{c}0.081 * * * \\
(2.64)\end{array}$ & & & & $\begin{array}{c}0.089 * * \\
(2.91)\end{array}$ & \\
\hline High Impact Settlement & & & & $\begin{array}{c}0.029 * * * \\
(2.79)\end{array}$ & & & & $\begin{array}{c}0.031 * * * \\
(2.61)\end{array}$ \\
\hline Proxy Fight & $\begin{array}{l}-0.012 \\
(-1.33)\end{array}$ & $\begin{array}{l}-0.011 \\
(-1.24)\end{array}$ & $\begin{array}{l}-0.013 \\
(-1.50)\end{array}$ & $\begin{array}{l}-0.014 \\
(-1.63)\end{array}$ & $\begin{array}{l}-0.010 \\
(-0.97)\end{array}$ & $\begin{array}{l}-0.009 \\
(-0.87)\end{array}$ & $\begin{array}{l}-0.011 \\
(-1.11)\end{array}$ & $\begin{array}{l}-0.013 \\
(-1.25)\end{array}$ \\
\hline Ln (Market Cap) & $\begin{array}{l}0.000 \\
(0.03)\end{array}$ & $\begin{array}{l}0.000 \\
(0.17)\end{array}$ & $\begin{array}{l}0.001 \\
(0.31)\end{array}$ & $\begin{array}{l}-0.000 \\
(-0.05)\end{array}$ & $\begin{array}{l}0.002 \\
(0.68)\end{array}$ & $\begin{array}{c}0.002 \\
(0.81)\end{array}$ & $\begin{array}{l}0.002 \\
(0.96)\end{array}$ & $\begin{array}{l}0.002 \\
(0.60)\end{array}$ \\
\hline Book / Market & $\begin{array}{l}-0.004 \\
(-0.48)\end{array}$ & $\begin{array}{l}-0.003 \\
(-0.42)\end{array}$ & $\begin{array}{l}-0.001 \\
(-0.16)\end{array}$ & $\begin{array}{l}-0.004 \\
(-0.48)\end{array}$ & $\begin{array}{l}0.003 \\
(0.28)\end{array}$ & $\begin{array}{l}0.003 \\
(0.32)\end{array}$ & $\begin{array}{l}0.005 \\
(0.55)\end{array}$ & $\begin{array}{l}0.003 \\
(0.28)\end{array}$ \\
\hline Observations & 360 & 360 & 360 & 360 & 360 & 360 & 360 & 360 \\
\hline R-Squared & 0.015 & 0.009 & 0.032 & 0.028 & 0.012 & 0.007 & 0.028 & 0.024 \\
\hline Adjusted R-Squared & 0.004 & -0.002 & 0.021 & 0.017 & 0.001 & -0.004 & 0.017 & 0.013 \\
\hline
\end{tabular}




\section{Table 11}

CEO turnover around settlement agreements.

This table presents difference-in-differences analyses of CEO turnover around settlement agreements. For target firms that settle ("Settled Campaigns"; all columns), we select untargeted control firms by propensity-scorematching on the year that the settlement agreement is reached. For target firms that experience a proxy contest vote (column 3), we select untargeted control firms by propensity-score-matching on the proxy contest announcement year. For target firms that experience neither settlement nor proxy contest vote ("Other Campaigns"; columns 2, 3), we select untargeted control firms by propensity-score-matching on the year of the initial activism announcement (in most cases the year of the first 13D filing). The tabulated coefficients measure how the difference between treatment firm CEO turnover and control firm CEO turnover has changed from the year before treatment/placebo (the omitted base year) to year $s \pm k, t \pm k$, or $c \pm k$. Treatment can either be the settlement year (for settled campaigns) or the proxy fight announcement year (for those proxy fights that went to a vote) or the year of the initial activism announcement (for "Other Campaigns" and "All Campaigns"). Columns 2 and 3 (column 3) include dummies for the Settlement (Voted Proxy) main effect. All columns include a set of $11 \mathrm{~d}[\mathrm{~s} \pm \mathrm{k}]$ dummies, one for each year relative to the settlement year (for treatment firms) and matched placebo year (for control firms). In addition, columns 2 and 3 (column 3) include another set of $11 \mathrm{~d}[\mathrm{t} \pm \mathrm{k}](\mathrm{d}[\mathrm{c} \pm \mathrm{k}])$ dummies, one for each year relative to the initial campaign launch year (proxy fight announcement year) and matched placebo year. At the bottom of the table, p-values of partial F-tests indicate the statistical significance of difference-in-differences estimations of CEO turnover around settlement agreements using year $\mathrm{t}-2$ as the base year. Coefficients and standard errors clustered by firm are estimated using OLS. T-statistics appear in parentheses. $* * *, * *, *$ denote statistical significance at the $1 \%, 5 \%$, and $10 \%$ level, respectively (two-tailed). All variables are defined in Appendix A.

\begin{tabular}{|c|c|c|c|}
\hline \multirow{2}{*}{$\begin{array}{l}\text { Dependent Variable } \\
\text { Sample }\end{array}$} & \multicolumn{3}{|c|}{ Prob (CEO Turnover) } \\
\hline & $\begin{array}{l}\text { Settled Campaigns \& } \\
\text { Control Firms }\end{array}$ & $\begin{array}{l}\text { Settled Campaigns, Other } \\
\text { Campaigns \& Control } \\
\text { Firms }\end{array}$ & $\begin{array}{c}\text { All Campaigns \& Control } \\
\text { Firms }\end{array}$ \\
\hline & (1) & $(2)$ & (3) \\
\hline Settlement $\cdot d[s-5]$ & $\begin{array}{l}-0.029 \\
(-0.94)\end{array}$ & $\begin{array}{l}-0.004 \\
(-0.14)\end{array}$ & $\begin{array}{l}-0.003 \\
(-0.11)\end{array}$ \\
\hline Settlement $\cdot \mathrm{d}[\mathrm{s}-4]$ & $\begin{array}{l}0.010 \\
(0.32)\end{array}$ & $\begin{array}{l}0.034 \\
(1.09)\end{array}$ & $\begin{array}{l}0.036 \\
(1.21)\end{array}$ \\
\hline Settlement $\cdot d[s-3]$ & $\begin{array}{l}-0.003 \\
(-0.10)\end{array}$ & $\begin{array}{l}0.011 \\
(0.36)\end{array}$ & $\begin{array}{l}0.013 \\
(0.44)\end{array}$ \\
\hline Settlement $\cdot d[s-2]$ & $\begin{array}{l}-0.010 \\
(-0.31)\end{array}$ & $\begin{array}{l}-0.003 \\
(-0.09)\end{array}$ & $\begin{array}{l}-0.002 \\
(-0.05)\end{array}$ \\
\hline Settlement $\cdot \mathrm{d}[\mathrm{s}]$ & $\begin{array}{c}0.077 * * \\
(2.18)\end{array}$ & $\begin{array}{c}0.063^{*} \\
(1.84)\end{array}$ & $\begin{array}{c}0.064^{*} \\
(1.94)\end{array}$ \\
\hline Settlement $\cdot d[s+1]$ & $\begin{array}{l}0.140 * * * \\
(3.43)\end{array}$ & $\begin{array}{c}0.132 * * * \\
(3.33)\end{array}$ & $\begin{array}{c}0.134 * * * \\
(3.48)\end{array}$ \\
\hline Settlement $\cdot d[s+2]$ & $\begin{array}{l}0.056 \\
(1.44)\end{array}$ & $\begin{array}{l}0.059 \\
(1.54)\end{array}$ & $\begin{array}{c}0.061^{*} \\
(1.66)\end{array}$ \\
\hline Settlement $\cdot d[s+3]$ & $\begin{array}{l}0.007 \\
(0.19)\end{array}$ & $\begin{array}{l}0.027 \\
(0.76)\end{array}$ & $\begin{array}{l}0.027 \\
(0.79)\end{array}$ \\
\hline Settlement $\cdot d[s+4]$ & $\begin{array}{l}0.003 \\
(0.07)\end{array}$ & $\begin{array}{l}0.031 \\
(0.81)\end{array}$ & $\begin{array}{l}0.031 \\
(0.84)\end{array}$ \\
\hline Settlement $\cdot d[s+5]$ & $\begin{array}{l}-0.021 \\
(-0.44)\end{array}$ & $\begin{array}{l}0.003 \\
(0.07)\end{array}$ & $\begin{array}{l}0.004 \\
(0.10)\end{array}$ \\
\hline $13 \mathrm{D} \cdot \mathrm{d}[\mathrm{t}-5]$ & & $\begin{array}{l}-0.021 \\
(-1.37)\end{array}$ & $\begin{array}{l}-0.019 \\
(-1.33)\end{array}$ \\
\hline $13 \mathrm{D} \cdot \mathrm{d}[\mathrm{t}-4]$ & & $\begin{array}{l}-0.007 \\
(-0.50)\end{array}$ & $\begin{array}{l}-0.009 \\
(-0.65)\end{array}$ \\
\hline $13 \mathrm{D} \cdot \mathrm{d}[\mathrm{t}-3]$ & & $\begin{array}{l}-0.015 \\
(-1.14)\end{array}$ & $\begin{array}{l}-0.016 \\
(-1.21)\end{array}$ \\
\hline $13 \mathrm{D} \cdot \mathrm{d}[\mathrm{t}-2]$ & & $\begin{array}{l}0.007 \\
(0.49)\end{array}$ & $\begin{array}{l}0.004 \\
(0.32)\end{array}$ \\
\hline
\end{tabular}


Table 11 (continued)

\begin{tabular}{|c|c|c|c|}
\hline \multicolumn{2}{|l|}{$13 \mathrm{D} \cdot \mathrm{d}[\mathrm{t}]$} & $\begin{array}{c}0.035^{* *} \\
(2.56)\end{array}$ & $\begin{array}{c}0.035^{* * * *} \\
(2.62)\end{array}$ \\
\hline \multicolumn{2}{|l|}{$13 \mathrm{D} \cdot \mathrm{d}[\mathrm{t}+1]$} & $\begin{array}{l}0.028^{*} \\
(1.86)\end{array}$ & $\begin{array}{c}0.029 * * \\
(2.01)\end{array}$ \\
\hline \multicolumn{2}{|l|}{$13 \mathrm{D} \cdot \mathrm{d}[\mathrm{t}+2]$} & $\begin{array}{c}0.032 * \\
(1.94)\end{array}$ & $\begin{array}{c}0.029^{*} \\
(1.80)\end{array}$ \\
\hline \multicolumn{2}{|l|}{$13 \mathrm{D} \cdot \mathrm{d}[\mathrm{t}+3]$} & $\begin{array}{l}0.009 \\
(0.57)\end{array}$ & $\begin{array}{l}0.007 \\
(0.47)\end{array}$ \\
\hline \multicolumn{2}{|l|}{$13 \mathrm{D} \cdot \mathrm{d}[\mathrm{t}+4]$} & $\begin{array}{l}-0.014 \\
(-0.95)\end{array}$ & $\begin{array}{l}-0.011 \\
(-0.78)\end{array}$ \\
\hline \multicolumn{2}{|l|}{$13 \mathrm{D} \cdot \mathrm{d}[\mathrm{t}+5]$} & $\begin{array}{l}-0.016 \\
(-0.95)\end{array}$ & $\begin{array}{l}-0.018 \\
(-1.12)\end{array}$ \\
\hline \multicolumn{2}{|l|}{ Voted Contest · d [c-5] } & & $\begin{array}{l}0.048 \\
(1.16)\end{array}$ \\
\hline \multicolumn{2}{|l|}{ Voted Contest $\cdot \mathrm{d}[\mathrm{c}-4]$} & & $\begin{array}{l}-0.004 \\
(-0.10)\end{array}$ \\
\hline \multicolumn{2}{|l|}{ Voted Contest $\cdot \mathrm{d}[\mathrm{c}-3]$} & & $\begin{array}{l}0.057 \\
(1.23)\end{array}$ \\
\hline \multicolumn{2}{|l|}{ Voted Contest $\cdot \mathrm{d}[\mathrm{c}-2]$} & & $\begin{array}{l}0.063 \\
(1.30)\end{array}$ \\
\hline \multicolumn{2}{|l|}{ Voted Contest $\cdot \mathrm{d}[\mathrm{c}]$} & & $\begin{array}{l}0.018 \\
(0.37)\end{array}$ \\
\hline \multicolumn{2}{|l|}{ Voted Contest $\cdot \mathrm{d}[\mathrm{c}+1]$} & & $\begin{array}{c}0.178 * * * \\
(2.75)\end{array}$ \\
\hline \multicolumn{2}{|l|}{ Voted Contest $\cdot \mathrm{d}[\mathrm{c}+2]$} & & $\begin{array}{c}0.147 * * \\
(2.53)\end{array}$ \\
\hline \multicolumn{2}{|l|}{ Voted Contest $\cdot \mathrm{d}[\mathrm{c}+3]$} & & $\begin{array}{l}-0.017 \\
(-0.36)\end{array}$ \\
\hline \multicolumn{2}{|l|}{ Voted Contest · d $[\mathrm{c}+4]$} & & $\begin{array}{c}0.156 * * \\
(2.47)\end{array}$ \\
\hline \multicolumn{2}{|l|}{ Voted Contest $\cdot \mathrm{d}[\mathrm{c}+5]$} & & $\begin{array}{l}0.006 \\
(0.10)\end{array}$ \\
\hline Firm \& Year FE & Yes & Yes & Yes \\
\hline Observations & 12,162 & 67,304 & 71,603 \\
\hline Adjusted R-Squared & 0.037 & 0.071 & 0.073 \\
\hline \multicolumn{4}{|c|}{ P-Values for Partial F-Tests Comparing Coefficients } \\
\hline $\mathrm{S} \cdot \mathrm{d}[\mathrm{s}]$ vs. $\mathrm{S} \cdot \mathrm{d}[\mathrm{s}-2]$ & 0.015 & 0.065 & 0.068 \\
\hline $\mathrm{S} \cdot \mathrm{d}[\mathrm{s}+1]$ vs. $\mathrm{S} \cdot \mathrm{d}[\mathrm{s}-2]$ & 0.000 & 0.001 & 0.001 \\
\hline $\mathrm{S} \cdot \mathrm{d}[\mathrm{s}+2]$ vs. $\mathrm{S} \cdot \mathrm{d}[\mathrm{s}-2]$ & 0.077 & 0.100 & 0.097 \\
\hline $\mathrm{S} \cdot \mathrm{d}[\mathrm{s}+3]$ vs. $\mathrm{S} \cdot \mathrm{d}[\mathrm{s}-2]$ & 0.648 & 0.425 & 0.445 \\
\hline $\mathrm{S} \cdot \mathrm{d}[\mathrm{s}+4]$ vs. $\mathrm{S} \cdot \mathrm{d}[\mathrm{s}-2]$ & 0.750 & 0.404 & 0.420 \\
\hline $\mathrm{S} \cdot \mathrm{d}[\mathrm{s}+5]$ vs. $\mathrm{S} \cdot \mathrm{d}[\mathrm{s}-2]$ & 0.819 & 0.893 & 0.893 \\
\hline
\end{tabular}




\section{Table 12}

The CEO turnover-performance sensitivity around settlement agreements.

This table presents analyses of the CEO turnover-performance sensitivity around settlement agreements. For target firms that settle ("Settled Campaigns"; all columns), we select untargeted control firms by propensity-scorematching on the year that the settlement agreement is reached. For target firms that experience a proxy contest vote (column 3), we select untargeted control firms by propensity-score-matching on the proxy contest announcement year. For target firms that experience neither settlement nor proxy contest vote ("Other Campaigns"; columns 2, 3), we select untargeted control firms by propensity-score-matching on the year of the initial activism announcement (in most cases the year of the first 13D filing). The tabulated coefficients on the three-way interactions measure how the difference between treatment firms' CEO turnover-sensitivity and control firms' CEO turnover-sensitivity changes from the three years before treatment/placebo $(\mathrm{POST}=0)$ to the year of and the two years following treatment/placebo (POST=1). Treatment can either be the settlement year (for settled campaigns) or the proxy fight announcement year (for those proxy fights that went to a vote) or the year of the initial activism announcement (for "Other Campaigns" and "All Campaigns"). Columns 1 to 3 (column 3) include dummies for the 13D and Settlement (Voted Proxy) main effects. All columns include a dummy variable d[POSTS] that is equal to 1 in the year of and the two years following the settlement year (for treatment firms) or placebo year (for control firms) and equal to 0 in the three years prior to the settlement or placebo. In addition, columns 2 and 3 (column 3) include d[POSTD] (d[POSTC]) dummy that is equal to 1 in the year of and the two years following the initial intervention year or matched placebo year (proxy fight announcement year or matched placebo year) and equal to zero in the three years prior to the initial intervention year or placebo year (proxy fight announcement year or placebo year). All relevant two-way interactions are included. Coefficients and standard errors clustered by firm are estimated using linear probability models. T-statistics appear in parentheses. ***, **, * denote statistical significance at the $1 \%, 5 \%$, and $10 \%$ level, respectively (two-tailed). All variables are defined in Appendix A.

\begin{tabular}{|c|c|c|c|}
\hline Dependent Variable & & Prob (CEO Turnover) & \\
\hline Sample & $\begin{array}{l}\text { Settled Campaigns \& } \\
\text { Control Firms }\end{array}$ & $\begin{array}{l}\text { Settled Campaigns, } \\
\text { Other Campaigns \& } \\
\text { Control Firms }\end{array}$ & $\begin{array}{l}\text { All Campaigns \& } \\
\text { Control Firms }\end{array}$ \\
\hline & (1) & (2) & (3) \\
\hline Stock Returns & $\begin{array}{c}-0.038 * * * \\
(-3.54)\end{array}$ & $\begin{array}{c}-0.029 * * * \\
(-6.22)\end{array}$ & $\begin{array}{c}-0.030 * * * \\
(-6.63)\end{array}$ \\
\hline Settlement $\cdot d[$ POSTS $] \cdot$ Stock Returns & $\begin{array}{c}-0.109 * * * \\
(-3.42)\end{array}$ & $\begin{array}{c}-0.094 * * * \\
(-3.02)\end{array}$ & $\begin{array}{c}-0.090 * * * \\
(-2.88)\end{array}$ \\
\hline 13D $\cdot \mathrm{d}[\mathrm{POSTD}] \cdot$ Stock Returns & & $\begin{array}{l}-0.015 \\
(-1.14)\end{array}$ & $\begin{array}{l}-0.015 \\
(-1.20)\end{array}$ \\
\hline Voted Contest $\cdot \mathrm{d}[\mathrm{POSTC}] \cdot$ Stock Returns & & & $\begin{array}{l}0.007 \\
(0.12)\end{array}$ \\
\hline Year FE & Yes & Yes & Yes \\
\hline Observations & 7,499 & 41,076 & 43,691 \\
\hline Adjusted R-Squared & 0.017 & 0.012 & 0.013 \\
\hline
\end{tabular}




\section{Table 13}

Payout policy around settlement agreements.

This table presents difference-in-differences analyses of payout yield around settlement agreements. For target firms that settle ("Settled Campaigns"; all columns), we select untargeted control firms by propensity-score-matching on the year that the settlement agreement is reached. For target firms that experience a proxy contest vote (column 3), we select untargeted control firms by propensity-score-matching on the proxy contest announcement year. For target firms that experience neither settlement nor proxy contest vote ("Other Campaigns"; columns 2, 3), we select untargeted control firms by propensity-score-matching on the year of the initial activism announcement (in most cases the year of the first 13D filing). The tabulated coefficients measure how the difference between treatment firm and control firm payout policy has changed from the year before treatment/placebo (the omitted base year) to year $s \pm k, t \pm k$, or $c \pm k$. Treatment can either be the settlement year (for settled campaigns) or the proxy fight announcement year (for those proxy fights that went to a vote) or the year of the initial activism announcement (for "Other Campaigns" and "All Campaigns"). Columns 2 and 3 (column 3) include dummies for the Settlement (Voted Proxy) main effect. All columns include a set of $11 \mathrm{~d}[\mathrm{~s} \pm \mathrm{k}]$ dummies, one for each year relative to the settlement year (for treatment firms) and matched placebo year (for control firms). In addition, columns 2 and 3 (column 3) include another set of $11 \mathrm{~d}[\mathrm{t} \pm \mathrm{k}](\mathrm{d}[\mathrm{c} \pm \mathrm{k}]$ ) dummies, one for each year relative to the initial campaign launch year (proxy fight announcement year) and matched placebo year. At the bottom of the table, p-values of partial F-tests indicate the statistical significance of difference-in-differences estimations of payout yield around settlement agreements using year $\mathrm{t}-2$ as the base year. Coefficients and standard errors clustered by firm are estimated using OLS. T-statistics appear in parentheses. $* * *, * *, *$ denote statistical significance at the $1 \%, 5 \%$, and $10 \%$ level, respectively (twotailed). All variables are defined in Appendix A.

\begin{tabular}{|c|c|c|c|}
\hline Dependent Variable & & Payout Yield & \\
\hline Sample & $\begin{array}{l}\text { Settled Campaigns \& } \\
\text { Control Firms }\end{array}$ & $\begin{array}{l}\text { Settled Campaigns, Other } \\
\text { Campaigns \& Control } \\
\text { Firms }\end{array}$ & $\begin{array}{c}\text { All Campaigns \& Control } \\
\text { Firms }\end{array}$ \\
\hline & (1) & $(2)$ & (3) \\
\hline Settlement $\cdot d[s-5]$ & $\begin{array}{c}-0.015 * * * \\
(-3.18)\end{array}$ & $\begin{array}{c}-0.010 * * \\
(-2.14)\end{array}$ & $\begin{array}{c}-0.010 * * \\
(-2.13)\end{array}$ \\
\hline Settlement $\cdot d[s-4]$ & $\begin{array}{l}-0.008 \\
(-1.52)\end{array}$ & $\begin{array}{l}-0.003 \\
(-0.47)\end{array}$ & $\begin{array}{l}-0.002 \\
(-0.38)\end{array}$ \\
\hline Settlement $\cdot \mathrm{d}[\mathrm{s}-3]$ & $\begin{array}{c}-0.010 * * \\
(-2.04)\end{array}$ & $\begin{array}{l}-0.005 \\
(-1.07)\end{array}$ & $\begin{array}{l}-0.005 \\
(-1.06)\end{array}$ \\
\hline Settlement $\cdot d[s-2]$ & $\begin{array}{c}-0.011 * * \\
(-2.27)\end{array}$ & $\begin{array}{l}-0.008 \\
(-1.63)\end{array}$ & $\begin{array}{l}-0.007 * \\
(-1.65)\end{array}$ \\
\hline Settlement $\cdot \mathrm{d}[\mathrm{s}]$ & $\begin{array}{l}0.011 \\
(1.60)\end{array}$ & $\begin{array}{l}0.011^{*} \\
(1.73)\end{array}$ & $\begin{array}{l}0.012^{*} \\
(1.90)\end{array}$ \\
\hline Settlement $\cdot d[s+1]$ & $\begin{array}{l}-0.002 \\
(-0.32)\end{array}$ & $\begin{array}{l}-0.001 \\
(-0.21)\end{array}$ & $\begin{array}{l}-0.000 \\
(-0.08)\end{array}$ \\
\hline Settlement $\cdot d[s+2]$ & $\begin{array}{l}0.005 \\
(0.76)\end{array}$ & $\begin{array}{l}0.008 \\
(1.11)\end{array}$ & $\begin{array}{l}0.009 \\
(1.30)\end{array}$ \\
\hline Settlement $\cdot d[s+3]$ & $\begin{array}{l}-0.005 \\
(-0.67)\end{array}$ & $\begin{array}{l}0.000 \\
(0.04)\end{array}$ & $\begin{array}{l}0.001 \\
(0.16)\end{array}$ \\
\hline Settlement $\cdot d[s+4]$ & $\begin{array}{l}-0.002 \\
(-0.32)\end{array}$ & $\begin{array}{l}0.005 \\
(0.68)\end{array}$ & $\begin{array}{l}0.005 \\
(0.79)\end{array}$ \\
\hline Settlement $\cdot d[s+5]$ & $\begin{array}{l}-0.007 \\
(-0.91)\end{array}$ & $\begin{array}{l}-0.001 \\
(-0.16)\end{array}$ & $\begin{array}{l}-0.001 \\
(-0.11)\end{array}$ \\
\hline $13 \mathrm{D} \cdot \mathrm{d}[\mathrm{t}-5]$ & & $\begin{array}{l}-0.001 \\
(-0.24)\end{array}$ & $\begin{array}{l}-0.001 \\
(-0.32)\end{array}$ \\
\hline $13 \mathrm{D} \cdot \mathrm{d}[\mathrm{t}-4]$ & & $\begin{array}{l}-0.003 \\
(-1.12)\end{array}$ & $\begin{array}{l}-0.003 \\
(-1.38)\end{array}$ \\
\hline $13 \mathrm{D} \cdot \mathrm{d}[\mathrm{t}-3]$ & & $\begin{array}{l}-0.003 \\
(-1.47)\end{array}$ & $\begin{array}{l}-0.003 \\
(-1.45)\end{array}$ \\
\hline $13 \mathrm{D} \cdot \mathrm{d}[\mathrm{t}-2]$ & & $\begin{array}{l}-0.001 \\
(-0.50)\end{array}$ & $\begin{array}{l}-0.001 \\
(-0.49)\end{array}$ \\
\hline
\end{tabular}


Table 13 (continued)

\begin{tabular}{|c|c|c|c|}
\hline \multicolumn{2}{|l|}{$13 \mathrm{D} \cdot \mathrm{d}[\mathrm{t}]$} & $\begin{array}{l}0.001 \\
(0.51)\end{array}$ & $\begin{array}{l}0.001 \\
(0.50)\end{array}$ \\
\hline \multicolumn{2}{|l|}{$13 \mathrm{D} \cdot \mathrm{d}[\mathrm{t}+1]$} & $\begin{array}{l}0.004 \\
(1.58)\end{array}$ & $\begin{array}{l}0.004 \\
(1.53)\end{array}$ \\
\hline \multicolumn{2}{|l|}{$13 \mathrm{D} \cdot \mathrm{d}[\mathrm{t}+2]$} & $\begin{array}{l}0.002 \\
(0.80)\end{array}$ & $\begin{array}{l}0.002 \\
(0.57)\end{array}$ \\
\hline \multicolumn{2}{|l|}{$13 \mathrm{D} \cdot \mathrm{d}[\mathrm{t}+3]$} & $\begin{array}{l}0.001 \\
(0.31)\end{array}$ & $\begin{array}{l}0.000 \\
(0.15)\end{array}$ \\
\hline \multicolumn{2}{|l|}{$13 \mathrm{D} \cdot \mathrm{d}[\mathrm{t}+4]$} & $\begin{array}{l}-0.004 \\
(-1.15)\end{array}$ & $\begin{array}{l}-0.004 \\
(-1.24)\end{array}$ \\
\hline \multicolumn{2}{|l|}{$13 \mathrm{D} \cdot \mathrm{d}[\mathrm{t}+5]$} & $\begin{array}{l}-0.005 \\
(-1.53)\end{array}$ & $\begin{array}{l}-0.005 \\
(-1.55)\end{array}$ \\
\hline \multicolumn{3}{|l|}{ Voted Contest $\cdot \mathrm{d}[\mathrm{c}-5]$} & $\begin{array}{c}0.025^{*} \\
(1.82)\end{array}$ \\
\hline \multicolumn{3}{|l|}{ Voted Contest $\cdot \mathrm{d}[\mathrm{c}-4]$} & $\begin{array}{c}0.010 \\
(1.30)\end{array}$ \\
\hline \multicolumn{3}{|l|}{ Voted Contest $\cdot \mathrm{d}[\mathrm{c}-3]$} & $\begin{array}{l}0.005 \\
(0.77)\end{array}$ \\
\hline \multicolumn{3}{|l|}{ Voted Contest $\cdot \mathrm{d}[\mathrm{c}-2]$} & $\begin{array}{l}0.005 \\
(0.56)\end{array}$ \\
\hline \multicolumn{3}{|l|}{ Voted Contest $\cdot \mathrm{d}[\mathrm{c}]$} & $\begin{array}{l}-0.002 \\
(-0.35)\end{array}$ \\
\hline \multicolumn{3}{|l|}{ Voted Contest $\cdot \mathrm{d}[\mathrm{c}+1]$} & $\begin{array}{l}0.005 \\
(0.59)\end{array}$ \\
\hline \multicolumn{3}{|l|}{ Voted Contest $\cdot \mathrm{d}[\mathrm{c}+2]$} & $\begin{array}{l}-0.005 \\
(-0.63)\end{array}$ \\
\hline \multicolumn{3}{|l|}{ Voted Contest $\cdot \mathrm{d}[\mathrm{c}+3]$} & $\begin{array}{l}-0.001 \\
(-0.09)\end{array}$ \\
\hline \multicolumn{3}{|l|}{ Voted Contest · d $[\mathrm{c}+4]$} & $\begin{array}{l}0.002 \\
(0.22)\end{array}$ \\
\hline \multicolumn{3}{|l|}{ Voted Contest $\cdot \mathrm{d}[\mathrm{c}+5]$} & $\begin{array}{l}-0.001 \\
(-0.11)\end{array}$ \\
\hline Firm \& Year FE & Yes & Yes & Yes \\
\hline Observations & 14,674 & 88,487 & 93,674 \\
\hline Adjusted R-Squared & 0.280 & 0.283 & 0.283 \\
\hline \multicolumn{4}{|c|}{ P-Values for Partial F-Tests Comparing Coefficients } \\
\hline $\mathrm{S} \cdot \mathrm{d}[\mathrm{s}]$ vs. $\mathrm{S} \cdot \mathrm{d}[\mathrm{s}-2]$ & 0.000 & 0.002 & 0.001 \\
\hline $\mathrm{S} \cdot \mathrm{d}[\mathrm{s}+1]$ vs. $\mathrm{S} \cdot \mathrm{d}[\mathrm{s}-2]$ & 0.108 & 0.247 & 0.218 \\
\hline $\mathrm{S} \cdot \mathrm{d}[\mathrm{s}+2]$ vs. $\mathrm{S} \cdot \mathrm{d}[\mathrm{s}-2]$ & 0.016 & 0.022 & 0.018 \\
\hline $\mathrm{S} \cdot \mathrm{d}[\mathrm{s}+3]$ vs. $\mathrm{S} \cdot \mathrm{d}[\mathrm{s}-2]$ & 0.318 & 0.191 & 0.180 \\
\hline $\mathrm{S} \cdot \mathrm{d}[\mathrm{s}+4]$ vs. $\mathrm{S} \cdot \mathrm{d}[\mathrm{s}-2]$ & 0.186 & 0.049 & 0.048 \\
\hline $\mathrm{S} \cdot \mathrm{d}[\mathrm{s}+5]$ vs. $\mathrm{S} \cdot \mathrm{d}[\mathrm{s}-2]$ & 0.517 & 0.316 & 0.320 \\
\hline
\end{tabular}




\section{Table 14}

Stock market delisting following settlement agreements.

This table presents analyses of the probability of different types of stock market delisting following settlement agreements. For target firms that settle (all columns), we select untargeted control firms by propensity-score-matching on the year that the settlement agreement is reached. For target firms that experience a proxy contest vote (columns $3,6,9$ ), we selected untargeted control firms by matching on the proxy contest announcement year. For target firms that experience neither settlement nor proxy contest vote (columns 2 , $3,5,6,8,9$ ), we select untargeted control firms by matching on the year of the initial activism announcement (in most cases the year of the first 13D filing). We exclude firm-years prior to the event years. To identify the coefficients in the absence of pre-periods, we include as a base group firms that were neither targeted nor selected as matched control firms. The tabulated coefficients measure the difference in the probability of delisting between treatment firms and matched control firms in the years following the treatment or placebo event. Treatment event can be the settlement announcement (all columns), the proxy fight announcement (columns 3,6,9), or the initial activism campaign announcement (columns $2,3,5,6,8,9)$. All columns include a set of $6 \mathrm{~d}[\mathrm{~s}+\mathrm{k}]$ dummies, one for each year relative to the settlement year (for treatment firms) and matched placebo year (for control firms). In addition, columns $2,3,5,6,8,9$ (columns $3,6,9)$ include another set of $6 \mathrm{~d}[\mathrm{t}+\mathrm{k}](\mathrm{d}[\mathrm{c}+\mathrm{k}])$ dummies, one for each year relative to the initial campaign launch year (proxy fight announcement year) and matched placebo year. Coefficients and standard errors clustered by firm are estimated using linear probability models. T-statistics appear in parentheses. ***,*** denote statistical significance at the $1 \%, 5 \%$, and $10 \%$ level, respectively (two-tailed). All variables are defined in Appendix A

\begin{tabular}{|c|c|c|c|c|c|c|c|c|c|}
\hline Dependent Variable & $\begin{array}{c}\text { Prob } \\
\text { (Delisting) }\end{array}$ & $\begin{array}{c}\text { Prob } \\
\text { (Acquisition / } \\
\text { Going Private } \\
\text { Delisting) }\end{array}$ & $\begin{array}{l}\text { Prob (Distress } \\
\text { Delisting) }\end{array}$ & $\begin{array}{c}\text { Prob } \\
\text { (Delisting) }\end{array}$ & $\begin{array}{c}\text { Prob } \\
\text { (Acquisition / } \\
\text { Going Private } \\
\text { Delisting) }\end{array}$ & $\begin{array}{l}\text { Prob (Distress } \\
\text { Delisting) }\end{array}$ & $\begin{array}{c}\text { Prob } \\
\text { (Delisting) }\end{array}$ & $\begin{array}{c}\text { Prob } \\
\text { (Acquisition / } \\
\text { Going Private } \\
\text { Delisting) }\end{array}$ & $\begin{array}{c}\text { Prob (Distress } \\
\text { Delisting) }\end{array}$ \\
\hline \multirow[t]{2}{*}{ Sample } & \multicolumn{3}{|c|}{ Settled Campaigns \& Control Firms } & \multicolumn{3}{|c|}{$\begin{array}{c}\text { Settled Campaigns, Other Campaigns \& } \\
\text { Control Firms }\end{array}$} & \multicolumn{3}{|c|}{ All Campaigns \& Control Firms } \\
\hline & (1) & (2) & (3) & $(4)$ & $(5)$ & (6) & (7) & (8) & (9) \\
\hline Settlement $\cdot d[s]$ & $\begin{array}{c}0.064 * * * \\
(2.93)\end{array}$ & $\begin{array}{c}0.067 * * * \\
(3.43)\end{array}$ & $\begin{array}{l}0.011 \\
(1.18)\end{array}$ & $\begin{array}{l}0.028 \\
(1.27)\end{array}$ & $\begin{array}{l}0.026 \\
(1.32)\end{array}$ & $\begin{array}{l}0.010 \\
(1.07)\end{array}$ & $\begin{array}{l}0.028 \\
(1.27)\end{array}$ & $\begin{array}{l}0.026 \\
(1.33)\end{array}$ & $\begin{array}{l}0.010 \\
(1.07)\end{array}$ \\
\hline Settlement $\cdot d[s+1]$ & $\begin{array}{l}0.010 \\
(0.46)\end{array}$ & $\begin{array}{l}0.022 \\
(1.23)\end{array}$ & $\begin{array}{l}-0.002 \\
(-0.18)\end{array}$ & $\begin{array}{l}-0.005 \\
(-0.24)\end{array}$ & $\begin{array}{l}0.002 \\
(0.11)\end{array}$ & $\begin{array}{l}-0.003 \\
(-0.29)\end{array}$ & $\begin{array}{l}-0.005 \\
(-0.24)\end{array}$ & $\begin{array}{l}0.002 \\
(0.10)\end{array}$ & $\begin{array}{l}-0.003 \\
(-0.36)\end{array}$ \\
\hline Settlement $\cdot d[s+2]$ & $\begin{array}{l}0.009 \\
(0.46)\end{array}$ & $\begin{array}{l}0.003 \\
(0.19)\end{array}$ & $\begin{array}{l}0.000 \\
(0.02)\end{array}$ & $\begin{array}{l}-0.004 \\
(-0.21)\end{array}$ & $\begin{array}{l}-0.011 \\
(-0.70)\end{array}$ & $\begin{array}{l}-0.004 \\
(-0.47)\end{array}$ & $\begin{array}{l}-0.004 \\
(-0.20)\end{array}$ & $\begin{array}{l}-0.011 \\
(-0.71)\end{array}$ & $\begin{array}{l}-0.004 \\
(-0.49)\end{array}$ \\
\hline Settlement $\cdot d[s+3]$ & $\begin{array}{l}0.008 \\
(0.45)\end{array}$ & $\begin{array}{l}0.009 \\
(0.61)\end{array}$ & $\begin{array}{l}0.009 \\
(0.77)\end{array}$ & $\begin{array}{l}-0.006 \\
(-0.30)\end{array}$ & $\begin{array}{l}-0.006 \\
(-0.40)\end{array}$ & $\begin{array}{l}0.006 \\
(0.54)\end{array}$ & $\begin{array}{l}-0.006 \\
(-0.30)\end{array}$ & $\begin{array}{l}-0.006 \\
(-0.41)\end{array}$ & $\begin{array}{l}0.006 \\
(0.57)\end{array}$ \\
\hline Settlement $\cdot d[s+4]$ & $\begin{array}{l}0.021 \\
(1.00)\end{array}$ & $\begin{array}{l}0.010 \\
(0.57)\end{array}$ & $\begin{array}{l}0.003 \\
(0.41)\end{array}$ & $\begin{array}{l}0.009 \\
(0.43)\end{array}$ & $\begin{array}{l}-0.007 \\
(-0.43)\end{array}$ & $\begin{array}{l}0.005 \\
(0.69)\end{array}$ & $\begin{array}{l}0.009 \\
(0.43)\end{array}$ & $\begin{array}{l}-0.007 \\
(-0.41)\end{array}$ & $\begin{array}{l}0.005 \\
(0.67)\end{array}$ \\
\hline Settlement $\cdot d[s+5]$ & $\begin{array}{l}0.048 * \\
(1.72)\end{array}$ & $\begin{array}{c}0.043^{*} \\
(1.85)\end{array}$ & $\begin{array}{l}0.007 \\
(0.59)\end{array}$ & $\begin{array}{l}0.041 \\
(1.47)\end{array}$ & $\begin{array}{l}0.033 \\
(1.43)\end{array}$ & $\begin{array}{l}0.009 \\
(0.75)\end{array}$ & $\begin{array}{l}0.041 \\
(1.48)\end{array}$ & $\begin{array}{l}0.034 \\
(1.45)\end{array}$ & $\begin{array}{l}0.009 \\
(0.74)\end{array}$ \\
\hline $13 \mathrm{D} \cdot \mathrm{d}[\mathrm{t}]$ & & & & $\begin{array}{c}0.066^{* * * *} \\
(6.17)\end{array}$ & $\begin{array}{c}0.067 * * * \\
(7.11)\end{array}$ & $\begin{array}{l}0.004 \\
(0.90)\end{array}$ & $\begin{array}{c}0.066 * * * \\
(6.25)\end{array}$ & $\begin{array}{c}0.067 * * * \\
(7.17)\end{array}$ & $\begin{array}{l}0.004 \\
(0.85)\end{array}$ \\
\hline $13 \mathrm{D} \cdot \mathrm{d}[\mathrm{t}+1]$ & & & & $\begin{array}{c}0.027 * * * \\
(2.85)\end{array}$ & $\begin{array}{c}0.035^{* * *} * \\
(4.25)\end{array}$ & $\begin{array}{l}-0.001 \\
(-0.24)\end{array}$ & $\begin{array}{c}0.027 * * * \\
(2.82)\end{array}$ & $\begin{array}{c}0.034 * * * \\
(4.23)\end{array}$ & $\begin{array}{l}-0.001 \\
(-0.28)\end{array}$ \\
\hline $13 \mathrm{D} \cdot \mathrm{d}[\mathrm{t}+2]$ & & & & $\begin{array}{l}0.005 \\
(0.57)\end{array}$ & $\begin{array}{c}0.012^{*} \\
(1.73)\end{array}$ & $\begin{array}{l}0.001 \\
(0.28)\end{array}$ & $\begin{array}{l}0.006 \\
(0.63)\end{array}$ & $\begin{array}{c}0.013^{*} \\
(1.83)\end{array}$ & $\begin{array}{l}0.003 \\
(0.60)\end{array}$ \\
\hline $13 \mathrm{D} \cdot \mathrm{d}[\mathrm{t}+3]$ & & & & $\begin{array}{c}0.021 * * \\
(2.20) \\
\end{array}$ & $\begin{array}{l}0.013^{*} \\
(1.79)\end{array}$ & $\begin{array}{c}0.009^{*} \\
(1.87)\end{array}$ & $\begin{array}{c}0.021 * * \\
(2.16) \\
\end{array}$ & $\begin{array}{l}0.013^{*} \\
(1.80)\end{array}$ & $\begin{array}{c}0.009^{*} \\
(1.79)\end{array}$ \\
\hline
\end{tabular}


Table 14 (continued)

\begin{tabular}{|c|c|c|c|c|c|c|c|c|c|}
\hline $13 \mathrm{D} \cdot \mathrm{d}[\mathrm{t}+4]$ & & & & $\begin{array}{l}0.013 \\
(1.32)\end{array}$ & $\begin{array}{c}0.017 * * \\
(2.18)\end{array}$ & $\begin{array}{l}-0.000 \\
(-0.07)\end{array}$ & $\begin{array}{l}0.013 \\
(1.38)\end{array}$ & $\begin{array}{c}0.018 * * \\
(2.21)\end{array}$ & $\begin{array}{l}-0.000 \\
(-0.10)\end{array}$ \\
\hline $13 \mathrm{D} \cdot \mathrm{d}[\mathrm{t}+5]$ & & & & $\begin{array}{l}0.015 \\
(1.31)\end{array}$ & $\begin{array}{c}0.023 * * \\
(2.41)\end{array}$ & $\begin{array}{l}-0.007 \\
(-1.60)\end{array}$ & $\begin{array}{l}0.014 \\
(1.30)\end{array}$ & $\begin{array}{c}0.021 * * \\
(2.26)\end{array}$ & $\begin{array}{l}-0.006 \\
(-1.44)\end{array}$ \\
\hline Voted Contest $\cdot \mathrm{d}[\mathrm{c}]$ & & & & & & & $\begin{array}{l}-0.008 \\
(-0.23)\end{array}$ & $\begin{array}{l}0.014 \\
(0.46)\end{array}$ & $\begin{array}{c}-0.026 * * * \\
(-3.47)\end{array}$ \\
\hline Voted Contest $\cdot \mathrm{d}[\mathrm{c}+1]$ & & & & & & & $\begin{array}{l}-0.006 \\
(-0.17)\end{array}$ & $\begin{array}{c}-0.047 * * \\
(-2.49)\end{array}$ & $\begin{array}{l}-0.011 \\
(-0.81)\end{array}$ \\
\hline Voted Contest $\cdot \mathrm{d}[\mathrm{c}+2]$ & & & & & & & $\begin{array}{l}0.014 \\
(0.40)\end{array}$ & $\begin{array}{l}0.004 \\
(0.12)\end{array}$ & $\begin{array}{l}0.015 \\
(0.70)\end{array}$ \\
\hline Voted Contest $\cdot \mathrm{d}[\mathrm{c}+3]$ & & & & & & & $\begin{array}{c}0.115^{* *} \\
(2.20)\end{array}$ & $\begin{array}{c}0.097 * * \\
(2.25)\end{array}$ & $\begin{array}{l}0.015 \\
(0.50)\end{array}$ \\
\hline Voted Contest $\cdot \mathrm{d}[\mathrm{c}+4]$ & & & & & & & $\begin{array}{l}0.028 \\
(0.73)\end{array}$ & $\begin{array}{l}-0.001 \\
(-0.03)\end{array}$ & $\begin{array}{l}0.012 \\
(0.78)\end{array}$ \\
\hline Voted Contest $\cdot \mathrm{d}[\mathrm{c}+5]$ & & & & & & & $\begin{array}{l}-0.022 \\
(-0.63)\end{array}$ & $\begin{array}{l}-0.022 \\
(-0.88)\end{array}$ & $\begin{array}{l}0.010 \\
(0.40)\end{array}$ \\
\hline Industry \& Year FE & Yes & Yes & Yes & Yes & Yes & Yes & Yes & Yes & Yes \\
\hline Observations & 84,178 & 84,178 & 84,178 & 123,663 & 123,663 & 123,663 & 126,565 & 126,565 & 126,565 \\
\hline Adjusted R-Squared & 0.044 & 0.028 & 0.027 & 0.036 & 0.023 & 0.021 & 0.036 & 0.023 & 0.021 \\
\hline
\end{tabular}




\section{Table 15}

Operating performance around settlement agreements.

This table presents difference-in-differences analyses of firm performance around settlement agreements. Columns 1 to 3 examine Return on Assets and models 4 to 6 Tobin's Q. For target firms that settle ("Settled Campaigns"; all columns), we select untargeted control firms by propensity-score-matching on the year that the settlement agreement is reached. For target firms that experience a proxy contest vote (columns 3 and 6), we select untargeted control firms by propensity-score-matching on the proxy contest announcement year. For target firms that experience neither settlement nor proxy contest vote ("Other Campaigns"; columns 2, $3,5,6$ ), we select untargeted control firms by propensity-score-matching on the year of the initial activism announcement (in most cases the year of the first 13D filing). The tabulated coefficients measure how the difference between treatment firm and control firm operating performance has changed from the year before treatment/placebo (the omitted base year) to year $\mathrm{s} \pm \mathrm{k}$, $\mathrm{t} \pm \mathrm{k}$, or $\mathrm{c} \pm \mathrm{k}$. Treatment can either be the settlement year (for settled campaigns) or the proxy fight announcement year (for those proxy fights that went to a vote) or the year of the initial activism announcement (for "Other Campaigns" and "All Campaigns"). Columns 2, 3, 5, and 6 (columns 3 and 6) include dummies for the Settlement (Voted Proxy) main effect. All columns include a set of $11 \mathrm{~d}[\mathrm{~s} \pm \mathrm{k}]$ dummies, one for each year relative to the settlement year (for treatment firms) and matched placebo year (for control firms). In addition, columns 2, 3, 5, 6 (columns 3 and 6) include another set of $11 \mathrm{~d}[\mathrm{t} \pm \mathrm{k}](\mathrm{d}[\mathrm{c} \pm \mathrm{k}])$ dummies, one for each year relative to the initial campaign launch year (proxy fight announcement year) and matched placebo year. At the bottom of the table, p-values of partial F-tests indicate the statistical significance of difference-in-differences estimations of firm performance around settlement agreements using year t-2 as the base year. Coefficients and standard errors clustered by firm are estimated using OLS. T-statistics appear in parentheses. ***, **, * denote statistical significance at the 1\%, 5\%, and 10\% level, respectively (two-tailed). All variables are defined in Appendix A.

\begin{tabular}{|c|c|c|c|c|c|c|}
\hline \multirow{2}{*}{$\begin{array}{l}\text { Dependent Variable } \\
\text { Sample }\end{array}$} & \multicolumn{3}{|c|}{ Return on Assets (ROA) } & \multicolumn{3}{|c|}{ Tobin's Q } \\
\hline & $\begin{array}{c}\text { Settled } \\
\text { Campaigns \& } \\
\text { Control Firms }\end{array}$ & $\begin{array}{c}\text { Settled } \\
\text { Campaigns, } \\
\text { Other } \\
\text { Campaigns \& } \\
\text { Control Firms }\end{array}$ & $\begin{array}{c}\text { All } \\
\text { Campaigns \& } \\
\text { Control Firms }\end{array}$ & $\begin{array}{c}\text { Settled } \\
\text { Campaigns \& } \\
\text { Control Firms }\end{array}$ & $\begin{array}{c}\text { Settled } \\
\text { Campaigns, } \\
\text { Other } \\
\text { Campaigns \& } \\
\text { Control Firms }\end{array}$ & $\begin{array}{c}\text { All } \\
\text { Campaigns \& } \\
\text { Control Firms }\end{array}$ \\
\hline & $(1)$ & $(2)$ & (3) & (4) & $(5)$ & (6) \\
\hline Settlement $\cdot d[s-5]$ & $\begin{array}{c}0.025 * * \\
(2.23)\end{array}$ & $\begin{array}{c}0.018 * \\
(1.70)\end{array}$ & $\begin{array}{l}0.020 * \\
(1.93)\end{array}$ & $\begin{array}{l}-0.027 \\
(-0.23)\end{array}$ & $\begin{array}{l}0.143 \\
(1.15)\end{array}$ & $\begin{array}{l}0.119 \\
(0.96)\end{array}$ \\
\hline Settlement $\cdot d[s-4]$ & $\begin{array}{l}0.014 \\
(1.59)\end{array}$ & $\begin{array}{l}0.008 \\
(0.93)\end{array}$ & $\begin{array}{l}0.010 \\
(1.24)\end{array}$ & $\begin{array}{l}-0.029 \\
(-0.33)\end{array}$ & $\begin{array}{l}0.142 \\
(1.53)\end{array}$ & $\begin{array}{l}0.116 \\
(1.25)\end{array}$ \\
\hline Settlement $\cdot d[s-3]$ & $\begin{array}{l}0.001 \\
(0.18)\end{array}$ & $\begin{array}{l}-0.003 \\
(-0.35)\end{array}$ & $\begin{array}{l}-0.001 \\
(-0.08)\end{array}$ & $\begin{array}{l}-0.109 \\
(-1.20)\end{array}$ & $\begin{array}{l}0.059 \\
(0.64)\end{array}$ & $\begin{array}{l}0.028 \\
(0.30)\end{array}$ \\
\hline Settlement $\cdot d[s-2]$ & $\begin{array}{l}0.002 \\
(0.35)\end{array}$ & $\begin{array}{l}0.002 \\
(0.28)\end{array}$ & $\begin{array}{l}0.003 \\
(0.55)\end{array}$ & $\begin{array}{l}-0.021 \\
(-0.24)\end{array}$ & $\begin{array}{c}0.147 * \\
(1.69)\end{array}$ & $\begin{array}{l}0.117 \\
(1.35)\end{array}$ \\
\hline Settlement $\cdot \mathrm{d}[\mathrm{s}]$ & $\begin{array}{l}-0.001 \\
(-0.24)\end{array}$ & $\begin{array}{l}0.003 \\
(0.53)\end{array}$ & $\begin{array}{l}0.005 \\
(0.79)\end{array}$ & $\begin{array}{l}0.050 \\
(0.60)\end{array}$ & $\begin{array}{c}0.223 * * * \\
(2.66)\end{array}$ & $\begin{array}{c}0.199 * * \\
(2.36)\end{array}$ \\
\hline Settlement $\cdot d[s+1]$ & $\begin{array}{l}0.013 \\
(1.60)\end{array}$ & $\begin{array}{l}0.013 \\
(1.62)\end{array}$ & $\begin{array}{c}0.015^{*} \\
(1.89)\end{array}$ & $\begin{array}{l}0.117 \\
(0.89)\end{array}$ & $\begin{array}{c}0.264 * * \\
(1.99)\end{array}$ & $\begin{array}{c}0.239^{*} \\
(1.82)\end{array}$ \\
\hline Settlement $\cdot d[s+2]$ & $\begin{array}{l}0.004 \\
(0.43)\end{array}$ & $\begin{array}{l}0.000 \\
(0.04)\end{array}$ & $\begin{array}{l}0.003 \\
(0.33)\end{array}$ & $\begin{array}{c}0.251 * * \\
(2.07)\end{array}$ & $\begin{array}{c}0.357 * * * \\
(3.06)\end{array}$ & $\begin{array}{c}0.333 * * * \\
(2.87)\end{array}$ \\
\hline Settlement $\cdot d[s+3]$ & $\begin{array}{l}0.007 \\
(0.54)\end{array}$ & $\begin{array}{l}0.002 \\
(0.14)\end{array}$ & $\begin{array}{l}0.004 \\
(0.35)\end{array}$ & $\begin{array}{l}0.153 \\
(1.10)\end{array}$ & $\begin{array}{c}0.228^{*} \\
(1.73)\end{array}$ & $\begin{array}{l}0.207 \\
(1.58)\end{array}$ \\
\hline Settlement $\cdot d[s+4]$ & $\begin{array}{l}0.004 \\
(0.36)\end{array}$ & $\begin{array}{l}-0.003 \\
(-0.22)\end{array}$ & $\begin{array}{l}-0.000 \\
(-0.00)\end{array}$ & $\begin{array}{l}0.234 \\
(1.45)\end{array}$ & $\begin{array}{c}0.337 * * \\
(2.05)\end{array}$ & $\begin{array}{c}0.307 * \\
(1.88)\end{array}$ \\
\hline Settlement $\cdot d[s+5]$ & $\begin{array}{l}0.008 \\
(0.76)\end{array}$ & $\begin{array}{l}0.003 \\
(0.28)\end{array}$ & $\begin{array}{l}0.005 \\
(0.49)\end{array}$ & $\begin{array}{l}0.317 \\
(1.45)\end{array}$ & $\begin{array}{c}0.431 * * \\
(2.10)\end{array}$ & $\begin{array}{c}0.397 * \\
(1.94)\end{array}$ \\
\hline $13 \mathrm{D} \cdot \mathrm{d}[\mathrm{t}-5]$ & & $\begin{array}{l}0.007 \\
(1.25)\end{array}$ & $\begin{array}{l}0.006 \\
(1.16)\end{array}$ & & $\begin{array}{l}-0.009 \\
(-0.13)\end{array}$ & $\begin{array}{l}-0.012 \\
(-0.17)\end{array}$ \\
\hline $13 \mathrm{D} \cdot \mathrm{d}[\mathrm{t}-4]$ & & $\begin{array}{l}0.007 \\
(1.59)\end{array}$ & $\begin{array}{l}0.007 \\
(1.43)\end{array}$ & & $\begin{array}{l}-0.024 \\
(-0.37)\end{array}$ & $\begin{array}{l}-0.034 \\
(-0.54)\end{array}$ \\
\hline $13 \mathrm{D} \cdot \mathrm{d}[\mathrm{t}-3]$ & & $\begin{array}{c}0.008^{*} \\
(1.89)\end{array}$ & $\begin{array}{l}0.006 \\
(1.54)\end{array}$ & & $\begin{array}{l}-0.004 \\
(-0.08)\end{array}$ & $\begin{array}{l}-0.003 \\
(-0.06)\end{array}$ \\
\hline $13 \mathrm{D} \cdot \mathrm{d}[\mathrm{t}-2]$ & & $\begin{array}{c}0.007 * * \\
(2.28)\end{array}$ & $\begin{array}{c}0.005^{*} \\
(1.88)\end{array}$ & & $\begin{array}{l}-0.007 \\
(-0.14)\end{array}$ & $\begin{array}{l}-0.002 \\
(-0.05)\end{array}$ \\
\hline $13 \mathrm{D} \cdot \mathrm{d}[\mathrm{t}]$ & & $\begin{array}{c}-0.009 * * * \\
(-3.07)\end{array}$ & $\begin{array}{c}-0.009 * * * \\
(-2.93)\end{array}$ & & $\begin{array}{l}-0.066 \\
(-1.42)\end{array}$ & $\begin{array}{l}-0.067 \\
(-1.49)\end{array}$ \\
\hline $13 \mathrm{D} \cdot \mathrm{d}[\mathrm{t}+1]$ & & $\begin{array}{l}-0.003 \\
(-0.61)\end{array}$ & $\begin{array}{l}-0.003 \\
(-0.67)\end{array}$ & & $\begin{array}{l}0.014 \\
(0.24)\end{array}$ & $\begin{array}{l}0.006 \\
(0.12)\end{array}$ \\
\hline
\end{tabular}


Table 15 (continued)

\begin{tabular}{|c|c|c|c|c|c|c|}
\hline \multicolumn{2}{|l|}{$13 \mathrm{D} \cdot \mathrm{d}[\mathrm{t}+2]$} & $\begin{array}{l}0.001 \\
(0.21)\end{array}$ & $\begin{array}{l}0.000 \\
(0.06)\end{array}$ & & $\begin{array}{l}-0.039 \\
(-0.66)\end{array}$ & $\begin{array}{l}-0.040 \\
(-0.68)\end{array}$ \\
\hline \multicolumn{2}{|l|}{$13 \mathrm{D} \cdot \mathrm{d}[\mathrm{t}+3]$} & $\begin{array}{l}0.005 \\
(0.83)\end{array}$ & $\begin{array}{l}0.003 \\
(0.57)\end{array}$ & & $\begin{array}{l}0.096 \\
(1.40)\end{array}$ & $\begin{array}{l}0.090 \\
(1.34)\end{array}$ \\
\hline \multicolumn{2}{|l|}{$13 \mathrm{D} \cdot \mathrm{d}[\mathrm{t}+4]$} & $\begin{array}{l}0.006 \\
(1.14)\end{array}$ & $\begin{array}{l}0.005 \\
(0.94)\end{array}$ & & $\begin{array}{l}0.071 \\
(0.94)\end{array}$ & $\begin{array}{l}0.057 \\
(0.79)\end{array}$ \\
\hline \multicolumn{2}{|l|}{$13 \mathrm{D} \cdot \mathrm{d}[\mathrm{t}+5]$} & $\begin{array}{c}0.010^{*} \\
(1.66)\end{array}$ & $\begin{array}{l}0.008 \\
(1.45)\end{array}$ & & $\begin{array}{l}0.023 \\
(0.26)\end{array}$ & $\begin{array}{l}0.038 \\
(0.46)\end{array}$ \\
\hline \multicolumn{2}{|l|}{ Voted Contest $\cdot \mathrm{d}[\mathrm{c}-5]$} & & $\begin{array}{l}-0.001 \\
(-0.04)\end{array}$ & & & $\begin{array}{l}-0.210 \\
(-0.80)\end{array}$ \\
\hline \multicolumn{2}{|l|}{ Voted Contest $\cdot \mathrm{d}[\mathrm{c}-4]$} & & $\begin{array}{l}0.006 \\
(0.30)\end{array}$ & & & $\begin{array}{l}-0.103 \\
(-0.42)\end{array}$ \\
\hline Voted Contest $\cdot \mathrm{d}[\mathrm{c}-3]$ & & & $\begin{array}{l}0.009 \\
(0.53)\end{array}$ & & & $\begin{array}{l}0.018 \\
(0.06)\end{array}$ \\
\hline Voted Contest $\cdot \mathrm{d}[\mathrm{c}-2]$ & & & $\begin{array}{l}0.013 \\
(0.99)\end{array}$ & & & $\begin{array}{l}-0.045 \\
(-0.19)\end{array}$ \\
\hline Voted Contest $\cdot \mathrm{d}[\mathrm{c}]$ & & & $\begin{array}{l}0.010 \\
(1.07)\end{array}$ & & & $\begin{array}{l}0.058 \\
(0.52)\end{array}$ \\
\hline Voted Contest $\cdot \mathrm{d}[\mathrm{c}+1]$ & & & $\begin{array}{c}0.039 * * \\
(2.15)\end{array}$ & & & $\begin{array}{l}-0.073 \\
(-0.45)\end{array}$ \\
\hline Voted Contest $\cdot \mathrm{d}[\mathrm{c}+2]$ & & & $\begin{array}{c}0.028 \\
(1.56)\end{array}$ & & & $\begin{array}{l}0.088 \\
(0.50)\end{array}$ \\
\hline Voted Contest $\cdot \mathrm{d}[\mathrm{c}+3]$ & & & $\begin{array}{c}0.046^{* *} \\
(2.03)\end{array}$ & & & $\begin{array}{l}0.154 \\
(0.48)\end{array}$ \\
\hline Voted Contest $\cdot \mathrm{d}[\mathrm{c}+4]$ & & & $\begin{array}{c}0.062 * * \\
(2.43)\end{array}$ & & & $\begin{array}{l}0.324 \\
(1.44)\end{array}$ \\
\hline \multicolumn{2}{|l|}{ Voted Contest $\cdot \mathrm{d}[\mathrm{c}+5]$} & & $\begin{array}{c}0.060 * * \\
(2.16)\end{array}$ & & & $\begin{array}{l}0.219 \\
(0.86)\end{array}$ \\
\hline Firm \& Year FE & Yes & Yes & Yes & Yes & Yes & Yes \\
\hline Observations & 15,642 & 95,711 & 101,574 & 15,805 & 96,957 & 102,880 \\
\hline Adjusted R-Squared & 0.752 & 0.704 & 0.71 & 0.536 & 0.515 & 0.514 \\
\hline \multicolumn{7}{|c|}{ P-Values for Partial F-Tests Comparing Coefficients } \\
\hline $\mathrm{S} \cdot \mathrm{d}[\mathrm{s}]$ vs. $\mathrm{S} \cdot \mathrm{d}[\mathrm{s}-2]$ & 0.621 & 0.842 & 0.864 & 0.552 & 0.530 & 0.502 \\
\hline $\mathrm{S} \cdot \mathrm{d}[\mathrm{s}+1]$ vs. $\mathrm{S} \cdot \mathrm{d}[\mathrm{s}-2]$ & 0.212 & 0.195 & 0.182 & 0.281 & 0.373 & 0.354 \\
\hline $\mathrm{S} \cdot \mathrm{d}[\mathrm{s}+2]$ vs. $\mathrm{S} \cdot \mathrm{d}[\mathrm{s}-2]$ & 0.859 & 0.898 & 0.961 & 0.065 & 0.152 & 0.141 \\
\hline $\mathrm{S} \cdot \mathrm{d}[\mathrm{s}+3]$ vs. $\mathrm{S} \cdot \mathrm{d}[\mathrm{s}-2]$ & 0.708 & 0.994 & 0.931 & 0.217 & 0.566 & 0.525 \\
\hline $\mathrm{S} \cdot \mathrm{d}[\mathrm{s}+4]$ vs. $\mathrm{S} \cdot \mathrm{d}[\mathrm{s}-2]$ & 0.856 & 0.730 & 0.788 & 0.137 & 0.292 & 0.292 \\
\hline $\mathrm{S} \cdot \mathrm{d}[\mathrm{s}+5]$ vs. $\mathrm{S} \cdot \mathrm{d}[\mathrm{s}-2]$ & 0.576 & 0.906 & 0.872 & 0.140 & 0.197 & 0.206 \\
\hline $\mathrm{S} \cdot \mathrm{d}[\mathrm{s}+1]$ vs. $\mathrm{S} \cdot \mathrm{d}[\mathrm{s}]$ & 0.027 & 0.138 & 0.118 & 0.605 & 0.756 & 0.760 \\
\hline $\mathrm{S} \cdot \mathrm{d}[\mathrm{s}+2]$ vs. $\mathrm{S} \cdot \mathrm{d}[\mathrm{s}]$ & 0.562 & 0.767 & 0.851 & 0.103 & 0.266 & 0.265 \\
\hline $\mathrm{S} \cdot \mathrm{d}[\mathrm{s}+3]$ vs. $\mathrm{S} \cdot \mathrm{d}[\mathrm{s}]$ & 0.489 & 0.911 & 0.992 & 0.476 & 0.972 & 0.954 \\
\hline $\mathrm{S} \cdot \mathrm{d}[\mathrm{s}+4]$ vs. $\mathrm{S} \cdot \mathrm{d}[\mathrm{s}]$ & 0.618 & 0.630 & 0.701 & 0.226 & 0.470 & 0.491 \\
\hline $\mathrm{S} \cdot \mathrm{d}[\mathrm{s}+5]$ vs. $\mathrm{S} \cdot \mathrm{d}[\mathrm{s}]$ & 0.388 & 0.987 & 0.967 & 0.254 & 0.362 & 0.387 \\
\hline
\end{tabular}




\section{Table 16}

Settlement agreements and annual director elections.

This table examines whether directors who are affiliated with or desired by the activists and appointed to the board following a settlement agreement receive lower voting support at future annual shareholder meetings than incumbent directors who were already on the board before the activism campaign launch. The sample for this analysis is restricted to settled activism campaigns. The independent variables of interest are indicator variables for the different director classifications, the omitted base case being incumbent directors who had been on the board prior to the activist intervention. Coefficients and standard errors clustered by firm are estimated using OLS. T-statistics appear in parentheses. $* * *, * *, *$ denote statistical significance at the $1 \%, 5 \%$, and $10 \%$ level, respectively (two-tailed). All variables are defined in Appendix A.

\begin{tabular}{lccc}
\hline & $\begin{array}{c}\text { Fraction of } \\
\text { Votes } \\
\text { Supporting } \\
\text { Director }\end{array}$ & $\begin{array}{c}\text { Fraction of } \\
\text { Votes Against } \\
\text { Director }\end{array}$ & $\begin{array}{c}\text { Fraction of } \\
\text { Votes Withheld }\end{array}$ \\
\hline Activist-Affiliated Directors Added Following Settlement & $(1)$ & $(2)$ & $(3)$ \\
Activist-Desired Directors Added Following Settlement & $0.017^{* *}$ & $-0.018^{* *}$ & 0.001 \\
& $(2.44)$ & $(-2.59)$ & $(0.82)$ \\
Other Directors Added Following Settlement & $0.038^{* * *}$ & $-0.039^{* * *}$ & 0.000 \\
& $(3.69)$ & $(-3.71)$ & $(0.76)$ \\
Firm \& Year FE & $0.039^{* *}$ & $-0.040^{* *}$ & $0.001^{*}$ \\
Observations & $(2.58)$ & $(-2.59)$ & $(1.74)$ \\
Adjusted R-Squared & Yes & Yes & Yes \\
P-Values for Partial F-Tests Comparing Coefficients & 4,027 & 4,027 & 4,027 \\
$\quad$ Affiliated Directors = Other Directors & 0.135 & 0.135 & 0.118 \\
Affiliated Directors = Desired Directors & 0.155 & 0.158 & 0.997 \\
Desired Directors = Other Directors & 0.045 & 0.046 & 0.791 \\
\hline
\end{tabular}

